Volume 25 | Issue 3

1993

\title{
The Convention for the Prohibition of Fishing with Long Driftnets in the South Pacific
}

Grant J. Hewison

Follow this and additional works at: https://scholarlycommons.law.case.edu/jil

Part of the International Law Commons

\section{Recommended Citation}

Grant J. Hewison, The Convention for the Prohibition of Fishing with Long Driftnets in the South Pacific, 25 Case W. Res. J. Int'l L. 449 (1993)

Available at: https://scholarlycommons.law.case.edu/jil/vol25/iss3/3

This Article is brought to you for free and open access by the Student Journals at Case Western Reserve University School of Law Scholarly Commons. It has been accepted for inclusion in Case Western Reserve Journal of International Law by an authorized administrator of Case Western Reserve University School of Law Scholarly Commons. 


\title{
The Convention for the Prohibition of Fishing With Long Driftnets in the South Pacific ${ }^{*}$
}

\author{
Grant J. Hewison"
}

I. INTRODUCTION

High seas driftnet fishing became the subject of intense regional concern in the South Pacific during 1988 when large numbers of Japanese and Taiwanese driftnet fishing vessels appeared in areas of high seas within the region. ${ }^{1}$ In the following 1988-89 fishing season the numbers of driftnet fishing vessels almost doubled, and in the 1989paper.

- The author accepts full responsibility for the accuracy and content of sources cited in this

* BA., LLB., Auckland University 1986; LLM (Hons), Auckland University 1992. Barrister and Solicitor of the High Court of New Zealand. Lecturer in Law, Auckland Institute of Technology, Auckland, New Zealand. I am grateful to Ms. Maree Underhill, Mr. Richard Hewison, the Centre for International Environmental Law, Greenpeace New Zealand, Ms. Mary Harwood (Australian Fisheries Service), Mr. Michael W. Lodge (South Pacific Forum Fisheries Agency), Dr. Talbot Murray (New Zealand Ministry of Agriculture and Fisheries), Professor I.V. Shearer (University of New South Wales - Australia) and Mr. David Taylor (New Zealand Ministry of Foreign Affairs and Trade) for their assistance in the preparation of this article. However, the analysis and views expressed in this article are my sole responsibility and do not necessary reflect the views of the people or institutions with which I am affiliated.

' See South Pacific Forum, Review of DRIFTnet Fishing IN THE SOUTH Pacific OCEAN, IsSUES AND IMPACTS, The SOUTH PACIFIC PERSPECTIVE (1991) thereinafter SOUTH PACIFIC FORUM] (held on file with the South Pacific Forum Fisheries Agency and the SecretaryGeneral of the United Nations. The paper was submitted to the Secretary-General of the United Nations by members of the South Pacific Forum (Australia, Cook Islands, Federated States of Micronesia, Fiji, Kiribati, Marshall Islands, Nauru, New Zealand, Niue, Papua New Guinea, Solomon Islands, Tonga, Tuvalu, Vanuatu, and Western Samoa) in consultation with the Forum Fisheries Agency, as requested in operative paragraph 4(a) of United Nations General Assembly Resolution 45/197, 1991); Report by the South Pacific Forum Fisheries Agency to the SecretaryGeneral of the United Nations Pursuant to General Assembly Resolution 44/225: Large Scale Pelagic Drifinet Fishing and Its Impact on the Living Marine Resources of the World's Oceans and Seas, Forum Fisheries Agency Report 90/33 (1990) [hereinafter Pelagic Drifinet Fishing]; James Carr \& Matthew Gianni, High Seas Fisheries, Large-Scale Driftnets, and the Law of the Sea, in FreedoM FOR THE SEAS IN THE 21ST CENTURY - OCEAN GOVERNANCE AND ENVIRONMENTAL HARMONY (Jon M. Van Dyke et al. eds., 1993) [hereinafter FREEDOM FOR THE SEAS]; Grant J. Hewison, High Seas Driftnet Fishing in the South Pacific and the Law of the Sea, 5 GEO. INT'L ENVTL. L. REV. 239 (1993); Kazuo Sumi, The International Legal Issues Concerning the Use of Driftnets, with Special Emphasis on Japanese Practices and Responses, in FREEDOM FOR THE SEAS, supra; A. Wright \& D. Doulman, Drift-net Fishing in the South Pacific - From Controversy to Management, 15 MARINE POL'Y 303 (1991) [hereinafter Wright \& Doulman]. 


\section{0 fishing season it tripled. ${ }^{2}$}

Driftnets used on the high seas are sections of gill net linked together to form longer nets which typically stretch up to 40 kilometers in length. ${ }^{3}$ These nets are left to drift in the open ocean capturing not only the target species, but also many other species of marine wildlife that swim into them. Large-scale pelagic driftnet fishing has been criticized for its capacity to over-exploit the target species and its non-selectiveness which results in the by-catch of economically undesirable fish species, as well as in many instances, rare and endangered marine mammals, birds, and other marine wildlife. ${ }^{4}$ Lost or discarded driftnets have

2 Pelagic Driftnet Fishing, supra note 1, tbl. 4.

${ }^{3}$ Driftnets observed in the South Pacific were typically gill nets constructed of a multifilament nylon mesh, consisting of thin cord woven from many mono-filament strands loosely twisted together, which hung in the water like a large curtain. A float line maintained one edge of the net on the surface of the water while a weighted lead-line on the bottom edge kept the net hanging down relatively slack. An individual net between 5 to 8 kilometers in length would generally be composed of a number of net panels (tans) of 39 meters or so in length. Five to ten individual nets would typically be laid end to end resulting in a combined net generally 40 kilometers or so in total length. The nets were 10 to 15 meters deep with a mesh size of 180 to 200 millimeters. Signal-activated radio beacons were sometimes attached to either end of each individual net. The nets were typically set from a vessel beginning around 1430 hours and finishing by about 1730 hours. The vessel would then return to the start position and begin hauling the nets back in at around 0230 hours. Hauling of a standard net would usually be complete by daybreak, but could take until mid-morning depending on the catch and the net condition. See PETER SHARPLES ET AL., REPORT OF OBSERVER ACTIVITY ON BOARD JAMARC DRIFTNET VeSSEl R.V. ShINHOYo Maru Fishing for albacore IN THE SOUTH PaCIFIC OCEan, 22 NovemBER-23 DECEMBER 1989 AND 10 FEBRUARY - 3 MARCH 1990 (1990) [hereinafter JAMARC] (South Pacific Commission Tuna and Billfish Assessment Programme Technical Report No. 24); Brian T. COFFEY \& Roger K. Grace, A Preliminary assessment of the IMPact of

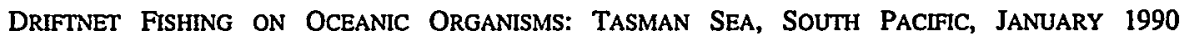
(1990) [hereinafter COFFEY \& GRACE 1990] (Greenpeace Pacific Campaign, Auckland, N.Z.).

+ See, e.g., James Carr \& Matthew Gianni, high Seas Ecosystems, Large-Scale DRIFINETS AND THE LAW OF THE SEA (1991) [hereinafter CARR \& GIANNI] (Greenpeace International, Amsterdam); SimON P. NORTHRIDGE, DRIFTNEt Fisheries AND THEIR IMPACTS ON NONTARGET SPECIES: A WORLDWIDE REVIEW (1990).

For a discussion of the catch of the driftnet fishery in the South Pacific, see for example, COFFEY \& GRACE 1990, supra note 3; ROBERT GOLDBLAT, MARINE RESOURCES MANAGEMENT DIVISION, YAP, FEDERATED STATES OF MICRONESIA, REPORT OF AN OBSERVER ON BOARD THE JAPANESE FISHING BOAT MONJU MARU DURING ITS TRIP IN YAP WATERS From FEBRUARY 3 TO MARCH 3, 1989 (1989); John Hampton et al., South Pacific Albacore Observer Programme 1988/89, South Pacific Commission, Twenty-First Regional Technical Meeting on Fisheries, Information Paper 6 (1989) [hereinafter Hampton et al, 1989]; John Hampton \& T. Murray, South Pacific Albacore Observer Programme on Troll Vessels, 1989-1990, Working Paper No. 2, in SOUTH PACIFIC COMMISSION, THIRd SOUTH PACIFIC ALBACORE RESEARCH (SPAR) WORKSHOP, OCTOBER 9-12, 1990 (1990) [hereinafter Hampton \& Murray 1990]; M.B. Harwood \& D. Hembree, Incidental Catch of Small Cetaceans in the Offshore Gillnet Fishery in Northern Australian Waters: 1981-1985, 37 REP. OF THE INT'L WHALING CoMmission 363 (1987) [hereinafter Harwood \& Hembree 1985]; D. Hembree \& M.B. Harwood, Pelagic Gillnet Modification Trials 
also added to the problem of plastic pollution in the marine environment and have presented a hazard to other vessels navigating through the high seas. $^{5}$

In the latter part of 1988, fisheries scientists and managers from the South Pacific region engaged in intensive consultations to determine the extent of the existing threat and the possible future threat from driftnet fishing. ${ }^{6}$ They concluded that: "in the South Pacific, where fisheries"

in Northern Australian Waters: 1981-1985, 37 REP. OF THE INT'L WHALING COMMISSION 369 (1987) [hereinafter Hembree \& Harwood 1987]; JAMARC, supra note 3; T. Murray, Review of Research and of Recent Developments in South Pacific Albacore Fisheries, with Emphasis on Large-Scale Pelagic Driftnet Fishing, in SOUTH PACIFIC COMMISSION, THIRD SOUTH PACIFIC ALBACORE RESEARCH (SPAR) WORKSHOP, OCTOBER 9-12, 1990 (1990) [hereinafter Murray 1990] (Information Paper No. 2); SOUTH PACIFIC ForUM, supra note 1; SOUTH PACIFIC COMMission,

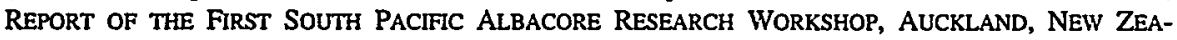
LAND, JUNE 9-12, 1986 (1986) [hereinafter SPAR 1]; SOUTH PACIFIC COMMISSION, REPORT OF THE SECOND SOUTH PACIFC ALbaCORE RESEARCH WORKSHOP, SUVA, Fui, JUNE 14-16, 1989 (1989) [hereinafter SPAR 2]; SOUTH PACIFC COMMISSION, REPORT OF THE THIRD SOUTH PACIFIC ALBACORE RESEARCH WORKSHOP, NOUMEA, NEW CALEDONIA, OCTOBER 9-12, 1990 (1990) [hereinafter SPAR 3]; Wright \& Doulman, supra note 1.

S See, e.g., Report of the Expert Consultation on Large-Scale Driftnet Fishing, U.N. FAO Fisheries Report No. 434, at 9, Para 45, U.N. Doc. FIPL/R434 (1990) [hereinafter FAO 434]; SOUTH PACIFIC FORUM, supra note 1, at 25; NEW ZEALAND MINISTRY OF AGRICULTURE AND

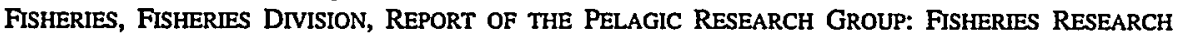
CENTRE (September 1989) [hereinafter MAF 1989] (on file with the New Zealand Ministry of Agriculture and Fisheries, Fisheries Division); NEw ZEALAND DEPARTMENT OF Conservation, Proceedings of NeW ZeAland's First National Workshop on Marine Debris IN OUR COASTAL WATERS, HELD MARCH 9, 1989 (1989) (on file with the New Zealand Department of Conservation); South Pacific Commission, Twentieth Regional Technical MeEting on Fisheries, A Review of the SOUTH PaCific AlbaCore FISHERY: Research and Fishing ACTTVITIES, SPC/Fisheries 20/WP. 13 (1988) [hereinafter SPC 1988 13]; Hampton et al. 1989, supra note 4. See also Protection of Living Resources from Entanglement in Fishing Nets and Debris: Report of the Committee on Fisheries, U.N. FAO Fisheries Comm., 17th Sess, U.N. Doc. MEPC 25/INF.3C.C (1987); D.L. Conner, The Tightening Net of Marine Plastics Pollution, 30 ENV'T 17 (1988); Christopher Joyner \& Scot Frew, Plastic Pollution in the Marine Environment, 22 OCEAN DEv. \& INT'L L. 33, 35 (1991); Bruce S. Manheim, Jr., Annex $V$ of the MARPOL Convention: Will It Stop Marine Plastic Pollution, 1 Geo. INT'L ENVT'L L. REv. 71 (1988); Albert M. Manville II, Aleutian Islands Plastics, Pelagic Drift and Trawl Net Problems, and Their Solutions, in TRANSActions of THE FIFTY-SIXTH NORTH AMERICAN WILDLIFE aNd NATURAL RESOURCES CONFERENCE, 205 (1991) [hereinafter Manville 1991].

It is interesting to note that although the problem of plastic pollution caused by plastic fishing gear was well-recognized at least two decades ago, it has not been resolved. Jon Jacobson noted in 1975 that "lost gear made from the new plastics and other 'nonrot' materials can have an adverse effect on fish stocks and the ocean ecology in general ... a lost, drifting monofilament gill net can also continue to entangle and kill fish." Jon L. Jacobson, Future Fishing Technology and Its Impact on the Law of the Sea, in LAW OF THE SEA: CARACAS AND BEYOND, A WORKSHOP OF THE LAW OF THE SEA INSTTUTE, 237 (F.T. Christy et al. eds., 1975).

- Consultation on Southern Albacore Fisheries Interaction, U.N. Development Programme, 
resources - primarily tuna - are a vital source of sustenance and revenue, . . . driftnet fishing is an inappropriate fishing practice which poses a real threat to the conservation and sustainable management of living marine resources, and hence the economy of the region."

The concerns of fisheries-scientists and managers were very quickly translated into political action by the governments of the region. In July 1989, the leaders of the South Pacific nations met at the annual South Pacific Forum. ${ }^{8}$ At the conclusion of the Forum, a joint Declaration was issued opposing driftnet fishing in the region in which the leaders of the South Pacific nations resolved: "for the sake of this and succeeding generations of Pacific peoples to seek the establishment of a regime for the management of albacore tuna in the South Pacific that would ban driftnet fishing from the region ....."9

In this Declaration, the South Pacific Forum further determined "to convene an urgent meeting of regional diplomatic, legal and fisheries experts to develop a Convention to give effect to its common resolve to create a zone free of driftnet fishing." 10

Taking a precedent from the South Pacific Nuclear Weapon Free Zone Treaty, ${ }^{11}$ the nations of the South Pacific solemnized their politi-

Regional Fisheries Support Programme, Forum Fisheries Agency and South Pacific Commission, SPEC Headquarters, Suva, Fiji, November 3-4, 1988 [hereinafter FFA First Consultation] (on file with the South Pacific Forum Fisheries Agency, Honiara, Solomon Islands); Consultation on Southern Albacore Fisheries Interaction, U.N. Development Programme, Regional Fisheries Support Programme, Forum Fisheries Agency and South Pacific Commission, SPEC Headquarters. Suva, Fiji, March 2-3, 1989 [hereinafter FFA Second Consultation] (on file with the South Pacific Forum Fisheries Agency, Honiara, Solomon Islands); D.A.P. Muller, High Seas Southern Albacore Driftnet Fishery Statement (Honiara, May 30, 1989) (media statement of Director of the South Pacific Forum Fisheries Agency - on file with the South Pacific Forum Fisheries Agency); SPAR 2, supra note 4; First Meeting on the Southern Albacore Driftnet Fishery, Agreed Record of Proceedings, Suva, Fiji, June 23-28, 1989 [hereinafter 1989 First Meeting] (on file with the South Pacific Forum Fisheries Agency).

7 South PACIFIC ForUM, supra note 1, at 2. "Ecological terrorism" is how Mr. Peter Tali Coleman, Governor of American Samoa, described driftnet fishing, at the 1989 Wellington Conference called to sign the Driftnet Convention. "The fish from the sea can sustain our people for generations to come but not if they are hauled off in driftnets faster than they can reproduce. Some say we are being emotional; others say we are over-reacting. I do not believe we are." Drifinet "Terrorism" Threat to Islanders, NEW ZEALAND HERALD, Nov. 27, 1989, at A12.

8 See Forum Communique, Twentieth South Pacific Forum, Tarawa, Kiribati, 10-11 JuLY 1989 (1989) (Published by the South Pacific Forum Secretariat). For a discussion of the South Pacific Forum, see The SOUTH Pacific Forum, South PaCific Forum SeCretariat, INFORMATION BULLETIN No. 32 (1988).

- Tarawa Declaration 1989, reprinted in FORUM COMMUNIQUE. TWENTIETH SOUTH PACIFIC ForUM TARAWA, KirIBATI, 10-11 JULY 1989, supra note 8, at 4-5 [hereinafter Tarawa Declaration 1989]; SOUTH PACIFIC FORUM, supra note 1, at 41.

10 Tarawa Declaration 1989, supra note 9; SOUTH PACIFIC FORUM, supra note 1, at 41.

II South Pacific Nuclear Free Zone Treaty, opened for signature Aug. 6, 1985, 24 I.L.M. 
cal resolve in a formal international instrument which was finalized and signed only four months later, during November 1989, in Wellington, New Zealand. The instrument, entitled the "Convention for the Prohibition of Fishing with Long Driftnets in the South Pacific"12 (hereinafter the "Driftnet Convention") has indeed heralded a zone free of driftnet fishing in the South Pacific and was one of the steps which led to the United Nations General Assembly, in December 1991, recommending a global moratorium on all high seas driftnet fishing. ${ }^{13}$ In addition to the small island nations of the South Pacific, larger nations such as Australia, New Zealand, the United States, and France have signed the Convention, while the United States has signed Protocol 1, and Canada and Chile have signed Protocol 2. ${ }^{14}$

This Article will examine the provisions of the Convention for the Prohibition of Fishing with Long Driftnets in the South Pacific and the contentions which have been raised concerning the validity of certain provisions of the Convention. ${ }^{15}$

1440 (1985) [hereinafter SPNFZ Treaty 1985].

12 Convention for the Prohibition of Fishing with Long Driftnets in the South Pacific, opened for signature Nov. 24, 1989, 29 I.L.M. 1449 (1990) [hereinafter Driftnet Convention 1989] (the Convention is also referred to as the "Wellington Convention"). See also Final Act to the Convention for the Prohibition of Fishing with Long Driftnets in the South Pacific, 29 I.L.M. 1453 (1990) [hereinafter Driftnet Convention Final Act]; Protocol 1 to the Driftnet Convention, Oct. 20, 1990, 29 I.L.M. 1462 (1990) [hereinafter Driftnet Convention Protocol 1 1989]; Protocol 2 to the Driftnet Convention, Oct. 20, 1990, 29 I.L.M. 1463 (1990) [hereinafter Driftnet Convention Protocol 2 1989]; Driftnet Convention Draft Exchange of Letters between the Director of the Forum Fisheries Agency and the Taiwan Deepsea Tuna Boat Owners and Exporters Association [hereinafter Driftnet Convention Draft Exchange of Letters] (on file with New Zealand Ministry of External Relations and Trade, Wellington).

13 See Large-Scale Pelagic Driftnet Fishing and its Impacts on the Living Marine Resources of the World's Oceans and Seas, U.N. GAOR 2nd Comm., 44th Sess., Annex, Agenda Item 82(f), U.N. Doc. A/RES/44/225 (1989) reprinted in 29 I.L.M. 1556 (1990) thereinafter U.N. GAOR Resolution 44/225]. See also Large-Scale Pelagic Driftnet Fishing and its Impacts on the Living Marine Resources of the World's Oceans and Seas, U.N. GAOR 2nd Comm., 45th Sess., Agenda Item 79, U.N. Doc. A/C.2/45/L.77 (1990) [hereinafter U.N. GAOR Resolution 45/L.77 1990].

14 The Cook Islands, Federated States of Micronesia, Marshall Islands, New Zealand, Niue, Palau, and Tokelau signed on the first day of the Wellington Conference, November 29, 1989. Australia signed on February 2, 1990. Kiribati, Nauru, Tuvalu, and Vanuatu signed on February 13, 1990. The Solomon Islands signed on March 7, 1990, France on April 30, 1990, and the United States on November 14, 1990. The United States signed Protocol 1 on February 26, 1991, and ratified Protocol 1 on February 28, 1992, while Canada and Chile signed Protocol 2 on September 24, 1991, and November 1, 1991, respectively.

is See I.A. Shearer, High Seas: Drift Gillnets, Highly Migratory Species, and Marine Mammals, in THE LAW OF THE SEA IN THE 1990s: A FRAMEWORK FOR FURTHER INTERNATIONAL COOPERATION 237 (Tadao Kuribayashi \& Edward L. Miles eds., 1992) (Proceedings of the Law of the Sea Institute's twenty-fourth Annual Conference with was held July 24-27, 1990, in To- 
The Article will begin by reviewing the drafting history of the Convention and its implementation by some of the nations which have ratified it to date. This will be followed by a detailed examination of the provisions of the Convention and legislation passed by a number of nations implementing these provisions.

\section{DRAFTING HISTORY}

As mentioned previously, the proposal to establish a Convention prohibiting driftnet fishing in the South Pacific emerged from the South Pacific Forum held in Tarawa, Kiribati during $1989 .{ }^{16}$

The concerns held by South Pacific nations about the effects of driftnet fishing prompted them to act quickly. At the 10th Anniversary of the founding of the South Pacific Forum Fisheries Agency, held in September 1989 , members took the opportunity to consider a draft Convention prepared by New Zealand officials. ${ }^{17}$ A further second draft was then developed from the New Zealand draft and circulated for consideration prior to the Wellington Conference. ${ }^{18}$

kyo, Japan); Chiyuki Mizukami, Fisheries Problems in the South Pacific Region, 15 MARINE POL'Y 111, 120 (1991).

16 Forum Communique, Twentieth South Pacific Forum, Tarawa, Kiribati, 10-11 July 1989, supra note 8.

17 The New Zealand Draft of the Driftnet Convention, September 1989 [hereinafter Driftnet Convention - New Zealand Draft 1989] (on file with the New Zealand Ministry of External Relations and Trade, Wellington).

${ }_{18}$ The Second Draft of the Driftnet Convention, September 1989 [hereinafter Driftnet Convention - Second Draft 1989](on file with the New Zealand Ministry of External Relations and Trade, Wellington), See also Francis Bugotu, in THE FoRUM FISHERIES AGENCY: ACHIEVEMENTS Challenges AND PRospects 29, 37 (Richard Herr ed., 1990) [hereinafter Herr 1990].

It is interesting to note the differences between the New Zealand draft, the Second draft. and the final version of the Driftnet Convention 1989:

(a) the Second draft alluded to international legal obligations in its Preamble which do not appear in the final version of the Driftnet Convention. In particular, the Second draft stated that there was a "duty on all States at international law to take, or to cooperate with other States in taking, measures to conserve the living resources of the high seas and also to cooperate in the conservation and management of the living resources concerned" and that "coastal States have sovereign rights for the purpose of exploration, exploitation, conservation and management of the living resources of their 200 nautical mile zones." The final version of the Driftnet Convention does, however, contain a general reference to the provisions of the LOS Convention in preambular paragraph 5;

(b) Article 1 of the Second draft contains the following reservation: "Nothing in this Convention or its Protocols shall be deemed to affect the rights, claims and legal view of any Party concerning the nature and extent of jurisdiction over fisheries." Although this phrase was removed in the final version of the Driftnet Convention, it appears in both of the Protocols to the final version of the Driftnet Convention;

(c) in the Second draft the measures to be taken against driftnet fishing activities are in a different order than in the final version. In the Second draft mandatory measures include prohib- 
The Conference to finalize the Driftnet Convention and formally open negotiations between coastal States of the region and distant water fishing nations for the establishment of a fisheries-management regime for albacore tuna was held in Wellington, New Zealand, between November 21-28, 1989. ${ }^{19}$ The nations and territories of the South Pacific sought, as a condition of membership in the albacore tuna management regime, that prospective members prohibit their nationals from driftnet fishing in the South Pacific and sign the Protocols to the Driftnet Convention. ${ }^{20}$

The Driftnet Convention was finalized and opened for signature on November 24, 1989, and was signed by a number of South Pacific nations on that date. ${ }^{21}$ It consists of 14 Articles which essentially require nations and territories in the South Pacific to prohibit their own nation-

iting the possession of driftnets and denying port access and port servicing facilities. In the final version of the Driftnet Convention these have become discretionary measures;

(d) the measure dealing with port access is stronger in the Second draft than in the final version of the Driftnet Convention. The draft "denies" port access and port servicing facilities, while the final version only "restricts" port access. The New Zealand draft includes an exemption for vessels in distress;

(e) enforcement in the New Zealand draft does not extend to withdrawal from good standing on the Regional Register of Foreign Fishing Vessels maintained by the South Pacific Forum Fisheries Agency, which appears to have been included at the meeting held during the 10th Anniversary of the founding of the Forum Fisheries Agency;

(f) the draft Protocols to the Second draft only require parties to prohibit nationals and fishing vessels from using driftnets and from assisting vessels engaging in driftnet fishing activities, including trans-shipment, or provisioning, whereas the Protocols to the final version of the Driftnet Convention contain further obligations (See infra notes 417-39 and accompanying main text).

19 The Conference was divided into three stages. The first stage (November 21-23) consisted of a meeting of South Pacific States and Territories, Canada, France, the United Kingdom, and the United States, who met to further draft and endorse the final Convention. Representatives of the South Pacific Forum Fisheries Agency, South Pacific Commission, South Pacific Forum Secretariat, South Pacific Regional Environmental Programme, and the European Community also attended. The non-governmental organizations Greenpeace and Earthtrust were invited to make written submissions. Prime Minister of New Zealand, South Pacific Driftnet Fishing Conference, Press Release (Nov. 13, 1989) (the Greenpeace written submission is on file with Greenpeace New Zealand, Auckland).

The second stage consisted of a meeting (November 24-25) between the above parties to establish general principles for the albacore tuna management regime. Id.

The third stage (November 27-28) was an initial consultation on the management regime for albacore tuna and involved both distant water fishing nations (Japan, the Republic of Korea, the United States, and representatives of the Taiwanese Fishing Industry) and the nations and territories of the South Pacific region. Canada, the EEC, France, and the United Kingdom were also invited as observers. At this meeting the distant water fishing nations were invited to sign the Protocols to the Driftnet Convention. Id.

20 Wright \& Doulman, supra note 1 , at 325.

21 See infra note 23. 
als from driftnet fishing and also to take measures, consistent with international law, to restrict driftnet fishing activities by distant water fishing nations in the region. ${ }^{22}$

\section{IMPLEMENTATION OF THE DRIFTNET CONVENTION}

To date fifteen nations and territories have signed the Driftnet Convention. ${ }^{23}$ The United States has signed and ratified Protocol 1, Canada and Chile have signed Protocol $2 .{ }^{24}$ Nine countries: Australia; the Cook Islands; the Federated States of Micronesia; Fiji; Kiribati; Nauru; New Zealand; Tokelau, and the United States have ratified the Driftnet Convention, which came into force on May 17, 1991.25

South Korea has expressed sympathy for Protocol 1, but indicated that before signing it would require conclusive scientific evidence of the dangers of driftnet fishing in the region. ${ }^{26}$ Japan has advised that it has no intention of signing the Protocols. ${ }^{27}$ Apart from Protocol 2, Canada is also considering signing Protocol $1 .^{28}$ There is no indication of Taiwanese intentions, but due to its status at international law, Taiwan is unable to sign the Protocols. ${ }^{29}$ There has also been consideration of the

22 Driftnet Convention 1989, supra note 12.

${ }^{23}$ The Cook Islands, Federated States of Micronesia, Marshall Islands, New Zealand, Niue, Palau, and Tokelau signed on the final day of the Wellington Conference, November 29, 1989. Australia signed on February 2, 1990. Kiribati, Nauru, Tuvalu, and Vanuatu ,signed on February 13, 1990. The Solomon Islands signed on March 7, 1990, France on April 30, 1990, and the United States on November 14, 1990. Those nations within the Convention Area, or nations which have territories within the Convention Area, but which have not yet signed or ratified the Convention are, Papua New Guinea, Tonga, the United Kingdom (for Pitcaim Island), and Western Samoa.

24 The United States signed Protocol 1 on February 26, 1991, and ratified Protocol 1 on February 28, 1992. Canada and Chile signed Protocol 2 on September 24, 1991, and November 1, 1991, respectively.

${ }^{25}$ These countries ratified the Convention on the following dates: Australia (July 7, 1992); Cook Islands (January 24, 1990); the Federated States of Micronesia (December 20, 1990); Fiji (January 18, 1994); Kiribati (January 10, 1992); Nauru (October 14, 1992); New Zealand (May 17, 1991); Tokelau (May 17, 1991); United States (February 28, 1992). Article 13(1) of the Driftnet Convention states that it shall enter into force on the date of deposit of the fourth instrument of ratification or accession.

${ }^{26}$ Wright \& Doulman, supra note 1, at 320 ("the Korean delegation explained that while the Korean government has assured South Pacific countries that its vessels would not drift-net in the region, it was concerned that if it signed Protocol 1 this might prejudice the operations of Korean drift-net fleets on (sic) the North Pacific. In short, Korea could not adopt an inconsistent position whereby it agreed to a ban in the South Pacific but not in the North Pacific.").

27 Id.

28 Id.

29 Only two nations in the region, Tonga and Tuvalu, officially recognize Taiwan. However, the Taiwanese delegation which attended the Conference was an official government representa- 


\section{EEC signing both Protocols. ${ }^{30}$}

\section{Legislative Responses IN the SOUTH PaCifiC}

Prior to the negotiation of the Driftnet Convention, many South Pacific nations and territories had already passed legislation prohibiting and/or restricting the practice of driftnet fishing in the region. However, those nations which have ratified the Driftnet Convention have also tended to pass further legislation specifically implementing provisions of the Convention. Not all the legislation passed in the South Pacific has been available to the present author, but the legislation passed by Australia, the Cook Islands, Guam, Hawaii, New Zealand, Tokelau, and the United States can be examined.

\section{A. Australia}

In 1979, Australia prohibited the use of driftnets off the coasts of New South Wales and Tasmania. ${ }^{31}$ In 1986, driftnets were also prohibited in northern Australian waters in an area from Broome to Cape York. ${ }^{32}$ This effectively ended the Taiwanese driftnet fishery for shark

tion and insisted that it be officially recognized as representing the "Republic of China." All the other nations at the Conference could not accept the Taiwanese representatives on this basis and they were denied access to the Conference. NEW SCIENTIST, Dec. 9, 1989, at 8.

To enable Taiwanese representatives to accept the provisions of the Driftnet Convention two letters were drafted containing obligations requiring Taiwanese vessels not to engage in driftnet fishing activities in the South Pacific, which were intended to be exchanged between the Director of the South Pacific Forum Fisheries Agency and the Taiwan Deepsea Tuna Boat Owners and Exporters Association. See supra note 12. See also infra notes 437-39 and accompanying text.

30 See Letter from Hon. D. McKinnon, New Zealand Minister of External Relations and Trade to Mr. Michael Hagler, Greenpeace New Zealand (July 29, 1991) (on file with the New Zealand Ministry of External Relations and Trade). However, the Convention would require amendment to permit an entity such as the EEC to sign. Article 10 of the Driftnet Convention provides that the Convention shall be open for signature by:

(a) any member of the FFA; and

(b) any State in respect of any Territory situated within the Convention Area

for which it is internationally responsible; or

(c) any Territory situated within the Convention Area which has been authorized to sign the Convention and to assume rights and obligations under it by the Government of the State which is internationally responsible for it. (Austl.).

31 Fisheries Notice No. 88 (July 19, 1979) (Austl.); Fisheries Notice No. 113 (Aug. 4, 1983)

32 Fisheries Notice No. 182 (Dec. 2, 1986) (Austl.) (this Notice restricted the length of the net to a maximum 2.5 kilometers). See John Kerin, Australian Minister of Primary Industry, Media Release (May 16, 1986) (on file with the Australian Ministry of Primary Industry). The action was taken to reduce the accidental kill of dolphins in Taiwanese driftnet fishing operations in the Arafua Sea, north of Australia. It was estimated that 14,000 dolphins of at least five dif- 
and mackerel which had been operating in these waters. ${ }^{33}$

On July 20,1989, the Australian Prime Minister announced a prohibition on the use of driftnets longer than $2.5 \mathrm{~km}$ in the entire Australian Fishing Zone and their carriage through the zone unless appropriately stowed. ${ }^{34}$ On July 19, 1991, Australia passed further legislation prohibiting any combination of driftnets exceeding a total length of 2.5 $\mathrm{km} .{ }^{35}$

Australia denies port access to, and the taking, processing, or transshipment of fish by foreign driftnet fishing vessels under sections 13BA and 13B of the Fisheries Act $1952{ }^{36}$ These sections provide that any foreign fishing vessel carrying out these activities without an appropriate license commits an offense against the Act. ${ }^{37}$ Foreign driftnet fishing vessels are simply not issued such licenses. ${ }^{38}$

Australia has both signed and ratified the Driftnet Convention. Section 13 of the new Fisheries Management Act, ${ }^{39}$ prohibits driftnet fishing activities within the Australian Fisheries Zone and prohibits citizens, Australian bodies corporate, or Australian boats from engaging in driftnet fishing activities outside the Australian Fisheries Zone. ${ }^{40}$ The penalties for offenses against this section are 50,000 Australian dollars for individuals and 250,000 Australian dollars for Australian bodies corporate. ${ }^{41}$ Driftnet fishing activities include taking fish, engaging in the

ferent species were taken this fishery between 1981 and 1985. Until the restriction, Taiwanese driftnet fishers were using nets between 15 and 20 kilometers long. As a result of the Australian restrictions, Taiwanese fishers decided they would stop driftnet fishing in this area altogether. Note that this media release also stated that: "[e]xtensive research into alternative methods of reducing the dolphin catch was undertaken over the past 18 months but the results had not proven satisfactory. This research included work on setting the gillnets deeper, reflecting devices, sound generation and other gear modifications." Id. See also M.B. Harwood et al., Incidental Take of Small Cetaceans in a Gillnet Fishery in Northern Australian Waters, 37 REP. OF THE INT'L WHALING COMMISSION 369 (1984); Harwood \& Hembree 1985, supra note 4; Hembree \& Harwood 1987, supra note 4; A.D. Read \& T. Ward, Taiwanese Longliners off Northem Australia, 45 AUSTL. FISHERIES 6, 6-8 (1989); Wright \& Doulman, supra note 1, at 314.

33 Wright \& Doulman, supra note 1.

34 Prime Minister of Australia, The State of the Environment, media release (July 21, 1989), excerpts reprinted in AUSTL. FISHERIES, Aug. 1989, at 10. See also Fisheries Notice No. AFZ 1 (July 20, 1989) (Austl.).

${ }^{35}$ Fisheries Notice No. AFZ 2 (July 19, 1991) (Austl.).

36 Fisheries Act 1952, §§ 13BA, 13B (Austl.).

37 Id.

${ }^{38}$ Correspondence between the Australian Fisheries Service and the author (Sept. 9, 1991) (on file with the author).

${ }^{39}$ Fisheries Management Bill, No. 162 (1991) (Austl.).

40 Id. § 13 .

4 Id. 
search for or activities which may result in taking fish, operations at sea preparing for any of these activities, transporting, trans-shipping and processing any driftnet catch, and co-operation in the provision of food, fuel, and other supplies for boats equipped for, or engaged in, driftnet fishing. ${ }^{42}$

\section{B. Cook Islands}

The Cook Islands was the first nation in the South Pacific to ratify the Driftnet Convention. ${ }^{43}$ The prohibitions on driftnet fishing are contained in a new Marine Resources Act $1989 . .^{44}$

Section 15 of the Marine Resources Act deals with driftnet fishing. ${ }^{45}$ No fishing vessel is to be used for or assist in any driftnet fishing activities in the Cook Islands or Cook Islands fishery waters ${ }^{46}$ and no fishing vessel registered in the Cook Islands is to be used for or may assist in driftnet fishing activities. ${ }^{47}$ No person is to engage in or assist with any driftnet fishing activities in the Cook Islands or Cook Islands fishery waters and no Cook Islands national is to engage in or assist with any driftnet fishing activities. ${ }^{48}$ Fines for offending against these provisions may be up to 250,000 New Zealand dollars and lead to seizure of the vessel. ${ }^{49}$

Section 2 of the Marine Resources Act defines driftnet fishing activities as "fishing with the use of a driftnet and any related activities including transporting, transshipping, and processing any driftnet catch, and provision of food, fuel, and other supplies for vessels used or outfitted for driftnet fishing." 50 In addition, the Minister responsible for issuing foreign fishing licenses may deny an application for a license to any fishing vessel which has engaged in any driftnet fishing activities. ${ }^{51} \mathrm{~A}$

42 Id. $\& 13(5)$. 1990.

43 See supra note 25. The Cook Islands ratified the Driftnet Convention 1989 on January 24,

' Marine Resources Act, No. 33 (1989) (Cook Islands).

is Id. \& 15.

45 The Cook Islands fishery waters are defined as "the waters of the territorial sea of the Cook Islands and of the exclusive economic zone and other internal waters, including lagoons, as defined in the Territorial Sea and Exclusive Economic Zone Act 1977, and includes any other waters over which the Government of the Cook Islands has fisheries jurisdiction." See id. § 2.

4 Id. $\S 15$.

${ }^{43}$ Id.

4 Section 31(2)(d) of the Cook Islands Marine Resources Act, 1989, outlines the powers of seizure. An authorized officer may seize "any vessel which he has reasonable grounds to believe has been or is being used in the commission of an offence . ..." Id. § 31(2)(d).

so $I d . \S 2$.

s1 $I d . \$ 16$. 
foreign fishing license may also be denied or canceled where good standing on the South Pacific Forum Fisheries Agency Regional Register has been withdrawn. ${ }^{52}$

\section{Guam}

Although Guam is an unincorporated territory of the United States and not able to become a party to the Driftnet Convention, Guam has consistently supported the position taken by the other nations and territories in the South Pacific and has passed its own legislation regarding driftnet fishing. ${ }^{53}$

On June 8, 1990, the Guam Legislature passed Public Law No. 20185 which prohibits the use, ${ }^{54}$ possession, and manufacture of pelagic driftnets. ${ }^{55}$ However, persons engaged in traditional fishing are exempt. ${ }^{56}$ In addition, Public Law No. 20-185 prohibits importation, transshipment, or possession of fish or fish products harvested with a pelagic driftnet $^{57}$ and provides for fines of up to 100,000 United States dollars for offenses against these sections and seizare of offending vessels and equipment. ${ }^{53}$

52 Id. § 23(3)(a). See also infra notes $386-99$ and accompanying text.

53 Guam is an unincorporated territory of the United States under the jurisdiction of the United States Department of the Interior. See POLITICAL HANDBOOK OF THE WORLD: 1990, 704, 705 (Arthur S. Banks et al. eds, 1990).

54 Public Law 20-185, § 3 (Guam). Subsection (c) of Section 12308.1 of the Government Code was amended by Public Law 20-185, $\$ 3$, to read "It shall be unlawful to use a gill net with a length greater than one thousand $(1,000)$ feet and no person shall intentionally set a net to drift in the waters of Guam."

ss Public Law 20-185, $\S 6$ (Guam). A new section 12385.1 is added by Public Law 20-185, $\S 6$, to the Government Code which states that: "[t]he manufacture, assembly, importation, transshipment, transfer from one vessel or aircraft to another vessel or aircraft, or possession of pelagic drift nets, components, or materials destined for their manufacture, in the territory or waters of Guam is prohibited."

56 Public Law 20-185, $\S 4$ (Guam). Section 4 permits two exceptions to the general prohibition contained in section 3. These are that "[n]o person other than an individual engaged in traditional fishing methods as that term is defined by Section $12300(\mathrm{~h})$ of the Government Code. or engaged in fishing for scientific purposes as permitted by the Division of Aquatic and Wildlife Resources of the Department of Agriculture shall take marine life with a gill net, including pelagic drift nets."

57 Public Law 20-185, § 7 (Guam). A new section 12385.2 has been added to the Government Code and states that "[t]he importation, transshipment, transfer from one vessel or aircraft to another vessel or aircraft, or possession of fish or fish products harvested with a pelagic drift net is prohibited in the territory, including the waters of Guam."

ss Public Law 20-185, \& 8 (Guam). The penalties include imprisonment of not more than five years, fines of not more than 100,000 United States dollars in particular cases, and forfeiture of vessels and equipment. It should be noted that the imprisonment of vessel crews, masters, etc., of foreign fishing vessels for fisheries offenses is considered contrary to international law and is expressly prohibited by Article 73 of the Law of the Sea Convention. United Nations 


\section{Hawaii}

Hawaii has the capacity to legislate for waters under State jurisdiction. $^{59}$ The Hawaiian State Legislature first presented Bill S.B. 1430 early in 1989 to take measures against driftnet fishing, but this bill was found to contain measures which were in conflict with Federal Law. ${ }^{60}$ A further bill, H.B. 20, was presented and enacted prohibiting any person from possessing or using any driftnet in the waters of the State. ${ }^{61}$

\section{E. New Zealand}

An increase in driftnet fishing activity near New Zealand in the late 1980 's led to a rise in the number of driftnet fishing vessels using the Port of Auckland for refuelling and re-provisioning. ${ }^{62}$ Although lacking clear legislative authority, the Auckland Harbour Board was persuaded to prohibit driftnet fishing vessels from entering the ports under its jurisdiction. ${ }^{63}$

Convention on the Law of the Sea, Dec. 10, 1982, U.N. Doc A/CONF.62/122, reprinted in 21 I.L.M. 1261 (1982) [hereinafter LOS Convention 1982].

s9 This is out to three nautical miles. See N. Bonucci, The Regulation of Driftnet Fishing 1 (a paper presented to an informal workshop organized by the Office of Ocean Affairs and Law of the Sea of the United Nations, the Legal Office of the United Nations Food and Agriculture Organization, OCA/PAC, the United Nations Environment Programme, held at Monaco, October $5,1990)$.

œ HAW. REv. STAT. §§ 188-30.5 (1989) (presented). This bill made it unlawful to possess or use a driftnet within the State's exclusive economic zone. The presence of a driftnet aboard any vessel was to be considered prima facie evidence of possession of a driftnet. No vessel found in violation of these provisions was to be permitted to use port facilities within the State for repairs, refuelling, or recreation, and no cargo from that vessel could be unloaded or transshipped within the State for a period of five years from the date of the violation. No person in the State of Hawaii was to accept driftnet-caught albacore tuna at canneries or cold facilities. A fine of 50,000 United States dollars could be imposed on violators.

61 HAW. REV. STAT. § 188 (1989).

62 Minutes of Meeting of the Auckland Harbour Board, (May 16, 1989) (on file with the author).

${ }^{63}$ On September 20, 1989, the Auckland Harbour Board passed a resolution introducing an amendment to an existing By-law No. 27. The amended by-law stated that:

No persons shall permit a vessel which carries, transports or bears any driftnet or which, within 3 months prior to its arrival in New Zealand waters, has been engaged in driftnet fishing, or any vessel of any company and its related subsidiaries associated with the aforementioned vessel, to enter Auckland Harbour or Manukau Harbour, or to anchor in any channel therein, or to moor therein, or to tie up at any wharf, pier or jetty therein, or to land at any landing place therein.

The Board, at its sole discretion, may require verification of compliance with this By-law by statutory declaration by the owner or accredited agent 
The New Zealand Government quickly followed by passing regulations under both the Fisheries Act 1908 (which prohibited the use and possession of driftnets by any person within New Zealand fisheries waters ${ }^{64}$ and the Territorial Sea and Exclusive Economic Zone Act 1977 (which prohibited the use and possession of driftnets by foreign vessels within the New Zealand EEZ). ${ }^{65}$

Following signature of the Driftnet Convention, the New Zealand Government passed the Driftnet Prohibition Act 1991 and revoked these regulations. ${ }^{66}$ The Driftnet Prohibition Act prohibits New Zealand nationals and vessels from engaging in driftnet fishing within the Convention Area established by the Driftnet Convention and prohibits any vessel or person from driftnet fishing within New Zealand's fisheries waters. ${ }^{67}$ It also prohibits driftnets onboard fishing vessels as well as the transportation, trans-shipment, landing, or processing of fish or marine life taken using a driftnet within New Zealand's fisheries waters. ${ }^{68}$ Driftnet fishing vessels are prohibited from entering the ports of New Zealand and the supply and provisioning of driftnet fishing vessels outside New Zealand's fisheries waters is prohibited. ${ }^{69}$ Extensive powers of search, arrest, and seizure are provided for and offenses against the act are prosecuted on the basis of strict liability. ${ }^{70}$ Offenders can be fined up to 250,000 New Zealand dollars and their property (including

prior to entry.

Although the opinion from the Board's and Greenpeace New Zealand's solicitors was that the Board did not have the necessary legislative authority to pass such a by-law, the Board did so, primarily to encourage the New Zealand Government to do likewise. The policy of the Board was successful. However, the Minister of Transport subsequently advised the Board that the bylaw was ultra vires and should be revoked, which was undertaken in March 1990.

44 Fisheries (Driftnet) Regulations 1989 (S.R. 1989/198) (N.Z.). These Regulations were passed pursuant to section 89 of the Fisheries Act 1983. New Zealand's fisheries waters are defined in section 2 of the Fisheries Act 1908 and include the exclusive economic zone, territorial sea, internal waters, and fresh or estuarine waters. See also infra note 65.

cs Exclusive Economic Zone (Driftnet) Regulations 1989 (S.R. 1989/197) (N.Z.). These Regulations were passed pursuant to section 22 of the Territorial Sea and Exclusive Economic Zone Act 1977. Both these and the Fisheries Act Driftnet Regulations came into effect on July 11, 1989. The two sets of Regulations were required to cover both foreign fishing vessels within New Zealand's Exclusive Economic Zone, which are regulated under the Territorial Sea and Exclusive Economic Zone Act 1977, and New Zealanders and New Zealand vessels which are regulated under the Fisheries Act 1908. Fines of up to 10,000 New Zealand dollars were provided for in each case.

66 Driftnet Prohibition Act, 1991 N.Z. Stat. No. 18 (1991).

${ }^{67}$ Id. $\$ \S 4,5$.

68 Id. \$§ 6-9.

$\rightarrow$ Id. $\$ \$ 10-11$.

70 Id. $\S \S 13-24$. 
vessels) forfeited. ${ }^{71}$ The Driftnet Prohibition Act also provides for defenses against certain offenses ${ }^{72}$ - for example - if the master of a vessel caught in possession of a driftnet can satisfy the Court that the vessel was not otherwise equipped to take fish with the driftnet, this is a defense. $^{73}$

\section{F. Tokelau}

New Zealand retains some law-making capacity for Tokelau and passed an amendment to the Tokelau (Exclusive Economic Zone) Fishing Regulations in 1989 which prohibits the use or possession of driftnets by any licensed foreign fishing vessel, the possession of driftnets within the Tokelau exclusive economic zone and territorial sea by any foreign fishing vessel and a prohibition on trans-shipment of catches within the Tokelau exclusive economic zone. ${ }^{74}$ It is interesting to note that these regulations make no mention of the use of driftnets by any Tokelauan. ${ }^{75}$

\section{G. United States Pacific Territories}

The United States Magnuson Fishery Conservation and Management Act of 1976 [hereinafter MFCMA] also applies to the United States Pacific Island Territories. ${ }^{76}$ The MFCMA was amended in 1990 to include provisions on driftnet fishing, which provide that the United States implement the moratorium recommended by United Nations General Assembly Resolution 44/225, support the Tarawa Declaration and the Driftnet Convention, and secure a permanent ban on the use of driftnets. ${ }^{n}$ The Secretary of Commerce must report to Congress about

71 Id. $\S \S 25-30$.

2 Id. $\S 28$.

3 Id. $\S 28(\mathrm{~b})$.

7 Tokelau (Exclusive Economic Zone) Fishing Regulations 1988, Amendment No. 1 (S.R. 1989/268) (N.Z.).

75 Id.

76 Magnuson Fishery Conservation and Management Act of 1976, 16 U.S.C. $\S \S 1802(21)$, 1811 [hereinafter MFCMA].

$\pi$ Fishery Conservation Amendments of 1990, Public Law No. 101-627, 104 Stat. 4436 (Nov. 28, 1990), $\S 107$. (to be codified at 16 U.S.C. 1826 (s. 206)). For a discussion of these amendments, see THE REgulation OF DRIFTNET FISHING ON THE HiGH SEAS: LEGAL ISSUES, U.N. Doc FAO Leg. Study 47, Annex 1, at 75 (1991) [hereinafter FAO Leg. Study 47] (the study contains papers by Ellen Hey, The Provisions of the United Nations Law of the Sea Convention on Fisheries Resources and Current International Fisheries Management Needs 1-11; William T. Burke, The Law of the Sea Concerning Coastal State Authority Over Drifinets on the High Seas 13-31; Doris Ponzoni, The International Legal Framework for the Conservation and 
actions taken by the United States regarding driftnets, and, in particular, provide a list of nations whose nationals practice driftnet fishing. ${ }^{78}$ If a nation is listed by the Secretary of Commerce it shall also be certified to the President and is subject to the provisions regarding the prohibition on imports established by the Pelly Amendment to the Magnuson Act. ${ }^{79}$ The Magnuson Act also now prohibits anyone from engaging in large-scale driftnet fishing in waters under United States jurisdiction and United States vessels are also prohibited from using driftnets outside these waters. ${ }^{80}$ The United States has also passed legislation encouraging the voluntary use of "Dolphin Safe" labelling on canned tuna products where the product was not caught with the use of driftnets. ${ }^{81}$

\section{APPRAISAL OF THE DRIFTNET CONVENTION}

Although the Driftnet Convention is a political statement, it is also a binding international legal instrument and contains some important, and in some respects, unique legal obligations.

International law is an especially important tool for small nations and territories, such as those in the South Pacific, whose political or economic ability to alter the policy of larger nations is very limited. Not only were these nations and territories concerned to establish a convention which reflected their political resolve, but they were also concerned that the measures proposed in the Driftnet Convention be considered lawful. They were particularly careful not to explicitly extend their fisheries jurisdiction out onto the high seas areas of the region, where in fact driftnet fishing was taking place. Instead they were content to prescribe measures which could be taken within their exclusive economic zones, but which would, nonetheless, make driftnet fishing on the high seas more difficult. The Driftnet Convention invites the distant water fishing nations to sign Protocols which would oblige them not to permit their nationals to fish using driftnets within the region. This approach is very similar to that which the nations and territories of the South Pacific had previously taken in establishing the South Pacific Nuclear Free Zone. However, there have been comments made that some of the pro-

Management of Living Marine Resources 33-43; and Kazuo Sumi, International Legal Issues Concerning the Use of Driftmets with Special Emphasis on Japanese Practices and Responses 4573). See also Leslie A. Davis, North Pacific Pelagic Driftnet Fishing: Untangling the High Seas Controversy, 64 S. CAL. L. REv. 1057, 1095 (1991).

${ }^{78}$ Fishery Conservation Amendments of 1990, supra note 77, § 107(e)(6).

${ }^{29}$ Id. \& 107(f).

\&o Id. \& 113(a).

81 Dolphin Protection Consumer Information Act, Public Law No. 101-627, 104 Stat. 4465-67 (Nov. 28, 1990), § 901 (to be codified at 16 U.S.C. 1835). 
visions of the Convention are arguably inconsistent with international law.

The remainder of this Article will examine the provisions of the Driftnet Convention. In particular, it will consider whether these provisions are "consistent" with international law. It will also review, compare, and assess the legislation passed by Australia, the Cook Islands, New Zealand, and Tokelau in ratifying the Convention.

\section{A. Definitions in the Driftnet Convention}

\section{The Convention Area}

The Convention Area encompasses all of the ocean between " 10 degrees North and 50 degrees South latitude and 130 degrees East and 120 degrees West longitude," including "all waters under the fisheries jurisdiction" of any party to the Convention. ${ }^{82}$ However, where a State is signing on behalf of a Territory within the region, (for example, France signing on behalf of New Caledonia), only the "waters under the fisheries jurisdiction of that Party, adjacent to the Territory" are included. $^{83}$

The incorporation of such an enormous area of ocean, including areas of high seas, in the Convention Area is, in fact, a common feature of treaties in the South Pacific region. The reasons for such a large Convention Area in the Driftnet Convention appear to be the following:

\section{a. Fishing Operations}

Driftnet fishing took place primarily in three areas of high seas in the South Pacific region: the Tasman Sea; an area east of New Zealand from 175 degrees to 155 degrees West Longitude; and an area further east from 155 degrees to 130 degrees West Longitude in the sub-tropical convergence zone. ${ }^{84}$ The Japanese fleet fished mainly in the Tasman Sea, with most vessels transferring to the far east of New Zealand in the middle of the fishing season anticipating the migration patterns of albacore tuna, while the Taiwanese and South Korean vessels tended to fish mainly in the sub-tropical convergence zone to the far east of New Zealand. ${ }^{85}$ The Convention Area amply covers these three driftnet fishing

22 Driftnet Convention 1989, supra note 12, art. 1.

ss Id. art. 1(a)(ii). In other words, the waters adjacent to the State itself (mainland France), outside the region, are not included within the Convention Area.

\& SPAR 3, supra note 4, at 10; JAMARC, supra note 3, at 2-3; COFFEY \& GRACE, supra note 3 , at 1,6 .

\&s Hampton \& Murray, supra note 4, at 2. 
areas.

\section{b. Ecological Coverage}

Albacore tuna are a highly migratory fish species which range throughout the South Pacific ocean. ${ }^{86}$ Although albacore tuna was the species targeted by driftnet fishers in the South Pacific, ${ }^{87}$ many other species were also incidentally caught. ${ }^{88}$ These species also tended to be highly migratory. ${ }^{89}$

The Convention Area appears to encompass within its boundaries the range of albacore tuna. The management area for the proposed Arrangement relating to the Management of South Pacific Albacore Tuna covers an area very similar to that of the Driftnet Convention..$^{90}$ It has been stated that the management area for this Arrangement was selected to "parallel the distribution of South Pacific albacore tuna."

In this sense the Driftnet Convention covers an area equating with the ecosystem which albacore tuna inhabit. ${ }^{92}$

86 Albacore tuna spawn mainly in sub-equatorial waters between 10 degrees and 20 degrees South Latitude. They then migrate southward as juvenile fish and are found in the surface layer of the sub-tropical convergence zone during the austral summer months. Their range extends from the South American coast westward into the waters of South Australia, but they are found particularly in the Tasman Sea, around New Zealand, and further to the east of New Zealand in the central South Pacific between 35 degrees and 40 degrees South Latitude and as far eastward as 130 degrees West Longitude. Albacore tuna also move eastward from the Tasman Sea into the areas to the east of New Zealand in the early austral summer months. During the austral winter months, they migrate north to tropical and sub-tropical waters where they are found at greater depths. See SPAR 2, supra note 4, at 9; Wright \& Doulman, supra note 1.

${ }^{87}$ See supra note 4.

88 The species primarily caught as bycatch in the driftnet fishery in the South Pacific included fish species (pomfret, flying squid, mako shark, blue shark, slender tuna, broadbill swordfish, a species of cubehead, pilotfish, and sunfish), marine mammals (common dolphin, striped dolphin, Risso's dolphin, pilot whale, and bottlenose whale), turtles, and birds. See JAMARC, supra note 4; COFFEY \& GRACE, supra note 3.

89e LOS Convention 1982, supra note 58, annex I. See also supra note 4.

90 Wright \& Doulman, supra note 1, at 325. See infra note 97 and accompanying text.

91 Wright \& Doulman, supra note 1.

92 Id. See also MOHAMmed DahMani, The FISHERIES Regime of the EXClusive Economic ZONE 36-37 (1987); DOUGLAS M. JOHNSTON \& EDGAR GOLD, LAW OF THE SEA INSTITUTE, UNIVERSITY OF RHODE ISLAND, THE ECONOMIC ZONE IN THE LAW OF THE SEA: SURVEY, ANALYSIS AND APPRAISAL OF CURRENT TRENDS 1-3 (1973) (Law of the Sea Institute Occasional Paper Series No. 17); BARBARA KWIATKOWSKA, THE 200 MILE EXClUSIVE ECONOMIC ZONE IN THE NEW LAW OF THE SEA 8 n.25 (1989). 


\section{c. Political Considerations}

As previously mentioned, the Driftnet Convention is as much a political statement as it is a legal instrument. It is a reflection of the political unity of the nations and territories of the South Pacific opposed to driftnet fishing, and thus its area also coincides with the political boundaries of the South Pacific region. ${ }^{93}$

\section{d. Other Regional Conventions}

There are three other important regional conventions in the South Pacific which have Areas including high seas: the South Pacific Nuclear Free Zone Treaty of 1985 (the SPNFZ Treaty 1985); ${ }^{94}$ the Convention for the Protection of the Natural Resources and Environment of the South Pacific Region of 1986 (the SPREP Convention 1986); ${ }^{95}$ and the Treaty on Fisheries Between the Governments of Certain Pacific Island States and the Government of the United States of 1987 (the U.S. Tuna Treaty 1987). ${ }^{96}$

93 For a discussion of the politics of the South Pacific nations and territories, see MICHAEL Hass, The PaCifiC WaY: Regional CoOperation IN THE SOUTH PaCIFIC (1989); Hetr 1990, supra note 18; THE SOUTH PACIFIC: PROBlems ISSUES AND PROSPECTS (R. Thakur ed., 1991); LAW, GOVERNMENT AND POLITICS IN THE PACIFIC ISLAND STATES (Yash Ghai ed., 1988).

I SPNFZ Treaty 1985, supra note 11. For a discussion of the provisions of this Treaty, see Bilkan Cicin-Sain \& Rosat W. Knecht, The Emergence of a Regional Ocean Regime in the South Pacific, 16 ECOLOGY L. QUARTERLY 171, $192-97$ (1989); Nigel Fyfe \& Christopher Beeby, The South Pacific Nuclear Free Zone, 17 VictoRIA U. Wellington L. REv. 33, $33-52$ (1986); Jeremy Guild, The Desirability and Feasibility of a South Pacific Nuclear Weapon Free Zone, 3 CANTERBURY L. REv. 125, 125-54 (1986); M. Lippan, The South Pacific Nuclear Free Zone Treaty: Regional Autonomy Verses International Law and Politics, 10 LoY. L.A. INT'L \& CoMP. L. J., 109, 109-33 (1988); P. Robert Philip, Jr., The South Pacific Nuclear-Weapon-Free-Zone, the Law of the Sea, and the ANZUS Alliance: An Exploration of Conflicts, a Step Toward World Peace, 16 CAL. W. INT'L L. J., 138. 138-77 (1986); Jon Van Dyke, The United States and Japan in Relation to the Resources, the Environment, and the Peoples of the Pacific Island Region, 16 ECOLOGY L.Q., 217, 219-20 (1989).

95 Convention for the Protection of the Natural Resources and Environment of the South Pacific Region, opened for signature, Nov. 25, 1986, 26 I.L.M. 38 (1987) [hereinafter SPREP Convention 1986]. For a discussion of the provisions of this Convention, see Cicin-Sain \& Knecht, supra note 94, at 190-92: F. Gubon, Steps taken by South Pacific Island States to Preserve and Protect Ocean Resources for Future Generations, in FREEDOM FOR THE SEAS, supra note 1; M. Pulea, The Unfinished Agenda for the Pacific to Protect the Ocean Environment, in FREEDOM FOR THE SEAS, supra note 1; S. Va'ai, The Convention for the Protection of the Natural Resources and Environment of the South Pacific: It's Strengths and Weaknesses, in FREEDOM FOR THE SEAS, supra note 1; Van Dyke, supra note 94, at 220-23.

\$6 Treaty on Fisheries Between Certain Pacific Island States and the United States, Apr. 2, 1987, 26 I.L.M. 1048 [hereinafter U.S. Tuna Treaty 1987]. For a discussion of this Treaty, see Cicin-Sain \& Knecht, supra note 94, at 186-90; G. Fong, Governance and Stewardship of the 
Another regional agreement being negotiated at present which will be important in this respect is the arrangement relating to the Management of South Pacific Albacore Tuna whose area parallels that of the Driftnet Convention Area. ${ }^{97}$

It might be noted in the discussion of these treaties that, in the first instance, the SPNFZ Treaty covers an enormous ocean area, including very extensive areas of high seas. ${ }^{98}$ The southern boundary of the SPNFZ Treaty Area adjoins the northern boundary of the Antarctic Treaty Area, which in itself is a zone free and applies to the area (including the high seas) south of 60 degrees South Latitude. ${ }^{99}$ The western boundary of the SPNFZ adjoins the nuclear free zone (again including areas of high seas) created by the Treaty of Tlatelolco. ${ }^{100}$ However, the SPNFZ Treaty explicitly provides that nothing "shall prejudice or in any way affect the rights, or the exercise of the rights, of any State under international law with regard to freedom of the seas."

The SPREP Convention Area comprises the 200-mile zones of the nations and territories of the South Pacific as well as those areas of the high seas in the South Pacific region that are enclosed from all sides by

Living Resources: The Work of the South Pacific Forum Fisheries Agency, in FREEDOM FOR THE SEAS, supra note 1; B.Martin Tsamenyi, The Treaty on Fisheries Benween the Governments of Certain South Pacific Island States and the Government of the United States of America: the Final Chapter in United States Tuna Policy, 15 BROOK. J. INT'L L. 183 (1989); Van Dyke, supra note 94, at 217-19.

97 A Possible Draft Arrangement Relating to the Management of South Pacific Albacore Tuna [hereafter called the Arrangement relating to the Management of South Pacific Albacore Tuna]. For a discussion of the provisions of this agreement, see Wright \& Doulman, supra note 1, at 320; SOUTH PACIFIC FORUM, supra note 1, at 52-61 (attachment 4).

98 SPNFZ Treaty 1985, supra note 11, art. 1(a), annex 1.

* The Antarctic Treaty, opened for signature, Dec. 1, 1959, 12 U.S.T. 794, 402 U.N.T.S. 72 [hereinafter Antarctic Treaty 1959]. The Treaty entered into force on June 23, 1961. Included among the States party to the Treaty are Australia, France, Japan, New Zealand, the United Kingdom, and the United States. Article 6 of the Antarctic Treaty states that:

[t]he provisions of the present treaty shall apply to the area south of $60^{\circ}$ South Latitude, including all ice shelves, but nothing in the present Treaty shall prejudice or in any way affect the rights, or the exercise of the rights, of any State under international law with regard to the high seas within that area.

Id. A similar provision is found in Article 2(2) of the SPNFZ Treaty. SPNFZ Treaty 1985, supra note 11, art. 2(2). For a discussion of the Antarctic Treaty see, Fyfe \& Beeby, supra note 94, at 38; INTERNATIONAL LAW FOR ANTARCTICA (Francesco Francioni \& Jullio Scovazzi eds., 1987); M.J. Peterson, MANAGING THE Frozen SOUTH: THE CREATION AND Evolution of the ANTARCTIC TREATY SYSTEM (1988); Philip, supra note 94, at 148.

100 Treaty for the Prohibition of Nuclear Weapons in Latin America, opened for signature, Feb. 14, 1967, 22 U.S.T. 754, 634 U.N.T.S. 281 [hereinafter Treaty of Tlatelolco 1967]. See Fyfe \& Beeby, supra note 94, at 38-39; Philip, supra note 94, at 148-50.

101 SPNFZ Treaty 1985, supra note 11, art. 2(2). 
these 200-mile zones. ${ }^{102}$ There is also provision in the SPREP Convention for the addition of any other areas under a party's jurisdiction within the Pacific Ocean between the Tropic of Cancer and 60 degrees South Latitude and between 130 degrees East Longitude and 120 degrees West Longitude. ${ }^{103}$ Furthermore, Protocol 1 to the Convention includes, together with the Convention Area, the continental shelf of a party where the shelf extends outward beyond the Convention Area. ${ }^{104}$

The U.S. Tuna Treaty generally covers the combined area of the 200-mile zones of the participating South Pacific island nations. ${ }^{105}$ However because the Treaty Area has been established using long straight boundary lines it also includes a number of enclaves of high seas and seeks to encompass the migratory boundaries of the tuna subject to the treaty. ${ }^{106}$

\section{e. Appraisal}

The inclusion of areas of high seas in a Convention in the South Pacific is by no means unusual and indeed, is a common feature of the major conventions of the region. It is also a feature of South Pacific "regionalism" which is based not only on geographical factors, but also

102 SPREP Convention 1986, supra note 95, arts. 1, 2. See also Cicin-Sain \& Knecht, supra note 94, at 192 (stating "the United States opposed the inclusion of extensive areas beyond the 200-mile zones of the participating island nations and territories, but eventually agreed to the inclusion of totally surrounded enclaves, but not fingers or corridors of high seas, as favoured by Kiribati and other nations."). Jon Van Dyke argues that the obligation in the SPREP Convention 1986 not to dump wastes in the high seas areas within the Convention Area:

appears to mean that the nations agree to prohibit other nonratifying states from dumping in the SPREP Treaty area, as well as agreeing not to dump themselves. This provision in the Treaty thus constitutes a claim for jurisdiction over disposal beyond the ratifying states' 200-mile zones. Any attempts to enforce such a provision against outside nations should raise some interesting legal questions.

Van Dyke, supra note 94, at 222.

${ }_{103}$ SPREP Convention 1986, supra note 95, arts. 3, 2(a)(iii).

las Protocol for the Prevention of Pollution of the South Pacific Region by Dumping, opened for signature Nov. 25, 1986, art. 2, 26 I.L.M. 38, 66 (1987) [hereinafter SPREP Convention 1986. Protocol 1].

10s U.S. Tuna Treaty 1987, supra note 96, art. 1.1(k).

${ }^{105}$ Id. See also Cicin-Sain \& Knecht, supra note 94, at 188:

U.S. negotiators may have believed that adopting a treaty area that was not created solely from the 200 -mile zones of the island states places them in a better position to argue that the Treaty is consistent with the U.S. view that highly migratory species such as tuna are to be managed by international agreements among the concerned states under article 64 of the 1982 Convention. 
on political, ethnic, and cultural factors. ${ }^{107}$ The areas of high seas are considered an inextricable part of this region.

However, the Conventions examined above have also been careful not to unilaterally extend sovereignty over areas of high seas and have either explicitly recognized high seas freedoms, ${ }^{108}$ or, if restricting high seas freedoms, have usually made the restrictions applicable only to the parties. However, the inclusion of areas of high seas within conventions in the South Pacific is a recurring feature and one accepted by a number of States with strong maritime interests. ${ }^{109}$

While the Driftnet Convention Area also encompasses considerable areas of high seas, the measures enumerated in Article 3, which operate to restrict driftnet fishing activities, apply only to the fisheries waters of the parties. ${ }^{110}$ In addition, distant water fishing nations are expected to bind themselves to these measures through Protocols. ${ }^{111}$ However, the Driftnet Convention does not "prevent a party from taking measures against driftnet fishing which are stricter than those required by the Convention," which opens the way for parties to take measures against driftnet fishing on the high seas within the Convention Area. ${ }^{112}$

Although it may be too soon to speak of South Pacific regional customary international law bestowing rights on the nations and territories of this region over activities on the region's high seas, there is certainly active regional "stewardship" over these areas. ${ }^{113}$

107 See generally Cicin-Sain \& Knecht, supra note 94; Van Dyke, supra note 94; FREEDOM FOR THE SEAS, supra note 1.

${ }^{103}$ See, e.g., SPNFZ Treaty 1985, supra note 11, art. 2(2).

109 The United States for example is a signatory to the SPREP Convention 1986 and the U.S. Tuna Treaty 1987.

110 Driftnet Convention 1989, supra note 12, art. 3.

"II Driftnet Convention Protocol 1 1989, supra note 12, art. 7; Driftnet Convention Protocol 2 1989, supra note 12, art. 7.

112 Driftnet Convention 1989, supra note 12, art. 3(3). See also the argument of W.T. Burke: Appropriate enforcement [of coastal States rights on the high seas] could take the form of disruption of the driftnet vessel operation by sufficiently disabling the nets to accomplish the conservation purpose. There would be no boarding or arrest of a foreign fishing vessel on the high seas, therefore no interference with the driftnet fishing vessels would be involved nor any claim to exercise jurisdiction over that vessel.

William T. Burke, Regulation of Driftnet Fishing on the High Seas and the New International Law of the Sea, 3 GEO. INT'L ENVTL. L. REV. 265, $295-96$ (1990).

"13 Although these claims have not been couched in specific terms, the actions of the nations of the South Pacific indicate that stewardship is an active practice:

[t] ]e region has moved ahead with the proposal for an international convention. In doing so, member states can point to the fact that in the South $\mathrm{Pa}$ cific region, multilateral treaties have been negotiated which contain regimes 


\section{Definition of a Driftnet}

The definition of a "driftnet" used in the Driftnet Convention is

a gillnet or other net or a combination of nets which is more than 2.5 kilometres in length the purpose of which is to enmesh, entrap or entangle fish by drifting on the surface of or in the water. ${ }^{114}$

Driftnets observed in the South Pacific were typically gill nets constructed of a multifilament nylon mesh. The nets were 10 to 15 meters deep with a mesh size of 180 or 200 millimeters. Five to ten individual nets of between 5 to 8 kilometers in length were often laid end to end resulting in a combined net on average 40 kilometers in total length. ${ }^{115}$

A standard definition for a driftnet is yet to emerge internationally, although the definitions found in national legislation are all very similar and conform generally with the definition used in the Driftnet Convention. ${ }^{116}$ One difficulty has been to determine a standard minimum length before a driftnet may be categorized as a large-scale pelagic driftnet. ${ }^{117} \mathrm{~A}$ minimum length of 2.5 kilometers appears to be emerg-

relating to the high seas, including the South Pacific Regional Environmental Programme, South Pacific Nuclear Free Zone Treaty and the Treaty on Fisheries ....

Neroni Slade, Foreign Fisheries Agency and the Next Decade: The Legal Aspects, in THE FORUM FiSHERIES AGENCY: ACHIEVEMENTS ChALlENGES AND PROSPECTS, supra note 18, at 296, 307. See also the "custodianship" doctrine championed by Canada in the 1970's, Brian D. Smith, STATE RESPONSIBILITY AND THE MARINE ENVIRONMENT, THE RULES OF DECISION 243, n.164 (1988); a regional environmental trusteeship for natural resources in the South Pacific, Pulea, supra note 95, at 110; and an Ocean Guardian, C.D. Stone, Mending the Sea through a Global Commons Trust Fund, in FREEDOM FOR THE SEAS, supra note 1, at 171.

114 Driftnet Convention 1989, supra note 12, art. 1(b).

us COFFEY \& GRACE, supra note 3 , at $1,5,11-12$; Wright \& Doulman, supra note 1 , at 307-8.

116 See, e.g., Fisheries Notice No. 182 (Dec. 11, 1986) (Austl.); EEC - Article 9, Proposal for Council Regulation (EEC) amending for the eleventh time Regulation (EEC) No. 3094/80 laying down certain technical measures for the conservation of fishery resources; Decreto 30 Marzo 1990: Misure tecniche concernenii la pesca del pesce spada con reti derivanti, Gazetta Ufficiale, No. 76, 31/3/90 (Italy); Driftnet Prohibition Act, N.Z. Stat. No. 18, § 2 (1991); MFCMA $\& 3$ (U.S.).

117 Total net length ranges between 35 and 50 kilometers for the North Pacific and South Pacific fisheries, between 6 and 7.5 kilometers for the North Atlantic fishery, between 20 and 25 kilometers in the Mediterranean, while the length of nets used in the Indian Ocean is unknown. See FAO 434, supra note 5 , at 79 , app. J. The approach has been to define a maximum length before a gillnet becomes a large scale driftnet. See FAO Leg. Study 47, supra note 77, annex 1; U.N. Doc. FAO Fisheries Technical Paper No. 222, in FAO 434, supra note 5, at 7, para. 39.

Dr. Armin Lindquist, on opening the FAO April 1990 Driftnet Consultation, asked: "What is a "large' pelagic driftnet, how should it be defined?" FAO 434, supra note 5 , at 30 , app. D. 
ing as a standard. A clear distinction has also been made between largescale pelagic "driftnets" used in open waters (or the high seas) and coastal artisinal gillnets. ${ }^{18}$

Although the Driftnet Convention defines driftnets to prevent nets of less than 2.5 kilometers being combined to form one longer net, there is no mention of the attachment or otherwise of the nets to a vessel or the seabed. It must be inferred that "drifting" implies lack of attachment to a vessel. Thus it is questionable whether a large-scale gill net attached to a vessel would be categorized as a driftnet, ${ }^{119}$ yet the effect on the marine environment would arguably be similar. ${ }^{120}$

Those nations which have implemented the Driftnet Convention in the South Pacific have used definitions of a driftnet which differ from that used in the Convention presenting possible difficulties in maintaining regional consistency. ${ }^{121}$

Another FAO meeting cautioned that: "in [the] absence of a clear and commonly agreed definition of what should be considered as a 'large' drifting gillnet, the regulation of the gear might raise some difficulties, in certain fisheries." Environment and Sustainability in Fisheries, U.N. Committee on Fisheries, 19th Sess., at 7, para. 29. U.N. Doc. FAO COFI/91/5 (1991) [hereinafter FAO Committee of Fisheries COFL/91/5]. See also Large-Scale Pelagic Driftnet Fishing and Its Impact on the Living Marine Resources of the World's Oceans and Seas: Report of the Secretary-General, U.N. Development and International Economic Cooperation, 45th Sess., Agenda Item 79, at 8, U.N. Doc. A/45/663 (1990) [hereinafter Secretary-General 1990].

118 This distinction is clearly made in United Nations Resolution 44/225, supra note 13, at preambular paras. 2,3.

For a discussion of the difference between the effects and management of coastal gillnets compared with large-scale pelagic driftnets, see Kuzuo Sumi, International Legal Issues Concerning the Use of Drifinets With Special Emphasis on Japanese Practices and Responses, in FAO Leg. Study 47, supra note 77, at 57-58 (arguing that the distinction between large-scale pelagic driftnets and coastal driftnets is not justified); Wright \& Doulman, supra note 1 (a small scale gill-net fishing technique is employed in inshore waters in some parts of the South Pacific); Secretary-General 1990, supra note 117, at 8, para. 7; CARR \& GIANNI 1991, supra note 4, at 8-10.

119 See Christine Stewart, Papua New Guinea law Reform Commission, Report on

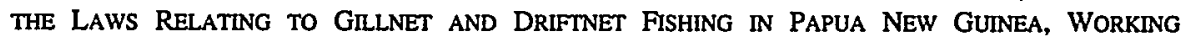
PAPER No. 25, 16 (1990).

120 Section 2 of the New Zealand Driftnet Prohibition Act 1991, makes a clear distinction between a net fixed to land or the sea bed and a "driftnet," while also including as a "driftnet" any net able to be attached to a vessel. A driftnet is defined as a gillnet or other net that, inter alia: "(d) Does not have attached to it sufficient means of anchoring it to any point of land or the sea bed (irrespective of whether the net has attached to it any means of being attached to any vessel)." Driftnet Prohibition Act, N.Z. Stat. No. 18, \& 2 (1991).

121 However, the differences are not great. See Fisheries Management Act, 1991, § 13(5) (Austl.); Marine Resources Act 1989, \& 2 (Cook Islands); Driftnet Prohibition Act, 1991, § 2 (N.Z.); Tokelau (Exclusive Economic Zone) Fishing Regulations 1988, Amendment No. 1, reg. 2 (N.Z.).

The Australian definition states: 


\section{Definition of Driftnet Fishing Activities}

The Driftnet Convention also specifically defines the phrase "driftnet fishing activities." These activities are the actual or attempted

"driftnet" means a gillnet or other net or a combination of nets that is more than 2.5 kilometers in length, or such shorter length as is prescribed, the purpose of which is to enmesh, entrap or entangle fish by drifting on the surface of or in the water.

This definition includes the ability to prescribe a shorter maximum length for a driftnet than $\mathbf{2 . 5}$ kilometer.

The Cook Islands definition states: "a gillnet or other net which is more than 2.5 kilometers in length the purpose of which is to enmesh, entrap or entangle fish; ...." The Cook Islands' definition differs from that used in the Driftnet Convention in an important respect. The Cook Islands' definition fails to include the phrase "any combination of nets." Consequently, a series of nets set together (but not joined), each of which is alone less than 2.5 kilometer in length, would not strictly be in breach of this legislation.

The New Zealand definition states:

"Driftnet" means a gillnet or other net that -

(a) Either singly or tied or connected together in combination with other nets is more than 1 kilometre in length; and

(b) Acts by enmeshing, entrapping, or entangling any fish or marine life; and

(c) Acts by drifting in the water, or on the surface of the water; and

(d) Does not have attached to it sufficient means of anchoring it to any point of land or the sea bed (irrespective or whether the net has attached to it any means of being attached to any vessel) .... .

The New Zealand definition is quite comprehensive, but differs in maintaining the New Zealand standard of $1 \mathrm{~km}$ (used in previous Regulations), see supra notes 64 and 65. It also seeks to make a clear distinction between "driftnets" and gillnets which are attached to the land or the sea bed.

The Tokelau definition of a driftnet is identical to that first used in the New Zealand Regulations. See supra note 50 and accompanying text. The Tokelau definition states:

Driftnet means a gillnet or any other net -

(i) Which is more than 1 kilometre in length; and

(ii) Which acts by enmeshing, entrapping, or entangling any fish; and

(iii) Which is used or intended to be used by being left to drift in, or on the surface of, the water; and

(iv) Which is not used or intended to be used while attached to any point of land or the sea bed irrespective of whether the net is used or intended to be used while attached to any vessel.

While the United States has not defined a "driftnet," it has at 16 U.S.C. § 1802(16) (1976) (amended 1990), defined driftnet fishing:

The term "large-scale driftnet fishing" means a method of fishing in which a gillnet composed of a panel or panels of webbing, or a series of such gillnets, with a total length of one and one-half miles or more is placed in the water and allowed to drift with the currents and winds for the purpose of entangling fish in the webbing. 
catching, taking, or harvesting of fish with the use of a driftnet and in addition any support operations, including searching for or locating fish (including operations of placing, searching for, or recovering fish aggregating devices or associated electronic equipment such as radio beacons), transporting, trans-shipping, or processing any catch, or supplying provisions to driftnet fishing vessels (including the use of aircraft for this purpose). ${ }^{122}$

The definition is very similar to the definition of "fishing" found in the U.S. Tuna Treaty, ${ }^{123}$ which itself seems to be based upon a combination of various definitions of "fishing" found in the national legislation of South Pacific nations and territories and the United States. ${ }^{124}$

\section{Definition of a Fishing Vessel}

The Driftnet Convention defines a fishing vessel as: "any vessel or boat equipped for or engaged in searching for, catching, processing or transporting fish or other marine organisms." 125

The definition of "fishing vessel" used in the Convention includes not only the vessel actually catching the fish, but also other support vessels. This follows the customary practice of States who often include vessels other than fishing vessels in their national legislative definitions of a "fishing" vessel. ${ }^{126}$ This is also a customary practice in the South

122 Driftnet Convention 1989, supra note 12, art. 1(c).

123 The U.S. Tuna Treaty 1987, supra note 96, art. 1.1(c). Article 1.1(c) of the U.S. Tuna Treaty defines "fishing" as:

(i) searching for, catching, taking or harvesting fish;

(ii) attempting to search for, catch, take or harvest fish;

(iii) engaging in any other activity which can reasonably be expected to result in the locating, catching, taking or harvesting of fish;

(iv) placing, searching for or recovering fish aggregating devices or associated electronic equipment such as radio beacons;

(v) any operations at sea directly in support of, or in preparation for any activity described in this paragraph; or

(vi) aircraft use, relating to the activities described in this paragraph except for flights in emergencies involving the health or safety of crew members or the safety of a vessel. Id.

124 See, e.g., Fisheries Act 1952, § 4 (Austl.); Marine Spaces Act 1977, § 2 (Fiji); Fisheries Ordinance 1977, § 2 (Kiribati); Territorial Sea and Exclusive Economic Zone Act 1977, § 2 (N.Z.); Fisheries Act 1972, \& 2 (Solom. Is.); MFCMA, § 3(10) (U.S.).

125 Driftnet Convention 1989, supra note 12, art. 1(e).

126 See Gerald Moore, National Legislation for the Management of Fisheries Under Extended Coastal State Jurisdiction, 11 J. MAR. L. \& COM. 153, 166 (1980). See, e.g., Coastal Fisheries Protection Act 1953, \& 2 (Can.); The Fisheries Act 1977, § 2 (Gam.); Maritime Boundaries Act 1977, § 2 (Guy.); Decree No. 5 of 1979 (Control of Foreign Fishing Vessels Decree), § 2 
Pacific. ${ }^{127}$ By comparison though, a less comprehensive definition was used in the U.S. Tuna Treaty. ${ }^{128}$

Some states also include in their national legislative definition of a fishing vessel, vessels which re-provision or refuel fishing vessels. ${ }^{129}$ However, the definition used in the Driftnet Convention does not clearly include these types of vessels.

Furthermore, the term "fishing vessel" used in the Driftnet Convention includes not only vessels actually engaged in fishing, but also those "equipped" for fishing. A difficulty may arise over what constitutes a vessel "equipped" for fishing. It appears that some vessels have been designed so that they can quickly convert from one gear type to another, perhaps fishing using one gear in one region and then converting to another gear (such as driftnets) for use in another region. ${ }^{130}$ Are these vessels, although not currently equipped for driftnet fishing, to be defined as driftnet fishing vessels? ${ }^{131}$

(Sey.); Fisheries Act 1979, § 28 (Sri Lanka); MFCMA, § 3(11) (U.S.). See also ROBERT W. SMITH, EXClusive ECONOMIC ZONE ClaIMS: AN ANALYSIS AND PRIMARY DOCUMENTS, 61-498 (1986) (containing a compendium of fisheries legislation).

127 See RegIONAL COMPENDIUM OF FISHERIES LEgISLATION (WESTERN PACIFIC REgion), U.N. FAO Legislative Series Study No. 35 (1984) [hereinafter FAO Regional Compendium]. See, e.g., Fisheries Act 1973, § 4 (Austl.); Marine Spaces Act 1977, § 2 (Fiji); Marshall Islands Marine Resources Jurisdiction Act of 1978, § 8402; Marine Resources Act 1978, § 2 (Nauru); Territorial Sea and Exclusive Economic Zone Act 1977, § 2 (Niue); Fisheries Act 1974, § 2 (Papua N.G.); Territorial Sea and Exclusive Economic Zone Act 1977, § 2 (N.Z.); Exclusive Economic Zone Act 1977, § 2 (W. Samoa).

${ }^{128}$ Article 1.1(d) of the U.S. Tuna Treaty provides: "fishing vessel of the United States" or "vessel" means any boat, ship or other craft which is used for, equipped to be used for, or of a type normally used for commercial fishing, which is documented under the laws of the United States." U.S. Tuna Treaty 1987, supra note 96, art. 1.1(d).

129 See 1 FAO REgIONAL COMPENDIUM, supra note 127, at 11, n.36. See also SMITH, supra note 126; Moore, supra note 126, at 166. See, e.g., Marine Boundaries and Jurisdiction Act, 1978-3, § 2 (Barb.); Marine Spaces Act, 1977, § 2 (Fiji); Marine Boundaries Act, 1978, § 2 (Gren.); Maritime Boundaries Act. 1977, \& 2 (Guy.); Territorial Sea and Exclusive Economic Zone Act, 1977, § 2 (N.Z.); Maritime Areas Act, 1984, \& 2 (St. Lucia); Territorial Sea and Exclusive Economic Zone Act. 1978, § 2 (Tonga).

130 This appeared to be the case with many of the vessels operating in the South Pacific. SOUTH PACIFIC FORUM, supra note 1, at 27 . See also FAO 434, supra note 5, at 7, para. 38:

In general, all offshore types of driftnet can be operated from a variety of types of vessel, and switching between gears or target species does not involve major refits. Recently, vessels in the pelagic driftnet fleets have included multi-purpose boats using at least two gear types. A fairly high proportion of vessels, particularly in the fleet of Taiwan (Province of China) are old, converted from other fisheries.

131 There have been suggestions that Russian vessels driftnet fishing in the North Pacific may have used a trawl gear while fishing in the South Pacific (in New Zealand waters), while re- 
Of those nations which have implemented the Driftnet Convention in the South Pacific, no nation has specifically included a definition of a driftnet fishing vessel, although their general fisheries laws do include definitions of fishing vessels. ${ }^{132}$

\section{B. Measures Against Driftnet Fishing Activities}

The measures to be taken by parties against driftnet fishing are found in Articles 2 and 3 of the Driftnet Convention ${ }^{133}$ which form the main operative provisions of the Convention. The measures are further divided into mandatory measures which parties are required to implement and discretionary measures which they are invited to implement. ${ }^{134}$

Articles 2 and $3(1)$ establish the mandatory measures. ${ }^{135}$ They require each party to prohibit their nationals and vessels from engaging in driftnet fishing activities and not to assist or encourage the use of driftnets within the Convention Area. They further require each party, consistent with international law, to restrict driftnet fishing activities within the Convention Area. Article 3(1) also requires parties to prohibit the use of driftnets and trans-shipment of driftnet catches within areas under their fisheries jurisdiction.

Article 3(2) establishes the discretionary measures parties may implement. ${ }^{136}$ Each party may take measures, consistent with international law, to: prohibit the landing of driftnet catches within their territory; prohibit the processing of driftnet catches in facilities under their jurisdiction; prohibit the importation of any fish or fish product which was caught using a driftnet; restrict port access and port servicing facilities to driftnet vessels and prohibit the possession of driftnets onboard any vessel within areas under their fisheries jurisdiction.

Article 3(3) of the Driftnet Convention states that "[n]othing in this Convention shall prevent a Party from taking measures against driftnet fishing activities which are stricter than those required by the Conven-

maining able to change back to driftnet gear.

132 Fisheries Act 1952, $\$ 2$ (Austl.); Marine Resources Act 1989, § 2 (Cook Islands); Territorial Sea and Exclusive Economic Zone Act 1977, § 2 (N.Z.); Tokelau (Territorial Sea and Exclusive Economic Zone) Act 1977, § 2 (N.Z.). The Cook Islands, for example, define a fishing vessel as "any vessel, boat, ship or other craft which is used for, equipped to be used for or of a type that is normally used for fishing or related activities." Marine Resources Act, $\S 2$ (1989) (Cook Islands).

133 Driftnet Convention 1989, supra note 12, arts. $2,3$.

134 Id.

135 Id. arts. 2, 3(1).

136 Id. art. 3(2). 
tion."137

This part of this Article will examine the mandatory measures provided for in Articles 2 and 3(1) and the discretionary measures provided for in Articles 3(2) and 3(3) of the Driftnet Convention. It will, howev$\mathrm{er}$, begin with a discussion of the drafting history of these measures and an analysis of the duties of coastal States regarding the navigation of fishing vessels through their fisheries zones, as the implementation of some of these measures may affect those duties.

\section{Drafting History of the Measures Against Driftnet Fishing}

During the drafting of the Driftnet Convention, there was some discussion and differences of view over which measures should be considered mandatory and which discretionary. ${ }^{138}$

The New Zealand draft of the Driftnet Convention provided for no discretionary measures. ${ }^{139}$ It required parties to take appropriate measures to restrict driftnet fishing operations in the Convention Area, including but not limited to: prohibiting driftnet fishing vessels from using driftnets within areas under its fisheries jurisdiction; prohibiting the trans-shipment of driftnet catches within areas under its jurisdiction; prohibiting the possession of driftnets onboard any fishing vessel within areas under its fisheries jurisdiction; and denying port access and port servicing facilities to driftnet fishing vessels except in cases of distress. ${ }^{140}$ In the Second draft of the Driftnet Convention, based on a New Zealand draft which was revised during the Conference held to commemorate the Forum Fisheries Agency's 10th Anniversary in September 1989, a number of new measures were introduced as well as the distinction established between measures considered mandatory and those considered discretionary. ${ }^{141}$ It is interesting to note that the mandatory measures still included the four mentioned above, while three new discretionary measures were introduced. The new discretionary measures invited parties to prohibit the landing of driftnet catches, the processing of driftnet catches and the importation of fish or fish products caught using driftnets. ${ }^{142}$ In the final version of the Driftnet Convention, the mandatory measures which required parties to prohibit the possession of driftnets onboard fishing vessels and to deny port access to driftnet fish-

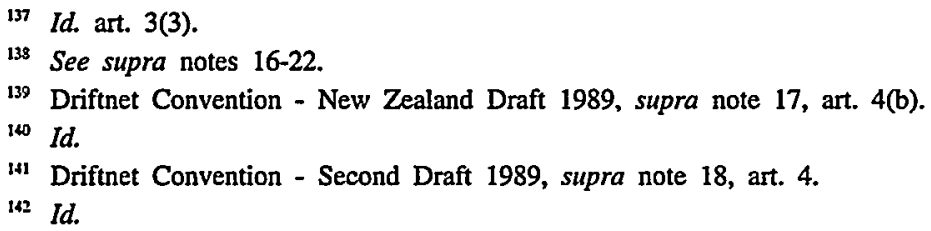


ing vessels now became discretionary measures, while the new discretionary measures introduced in the Second draft remained discretionary. ${ }^{143}$

Only representatives from nations and territories in the South $\mathrm{Pa}-$ cific were present at the negotiations which produced the Second draft of the Driftnet Convention, while representatives from nations such as the United States, the United Kingdom, and France were present at the final negotiations held in Wellington. ${ }^{144}$ Although the negotiations were held in camera it may be surmised, from the differences between the Second draft of the Driftnet Convention and the final version of the Driftnet Convention, that at least some of the representatives from these "metropolitan" nations felt they could not accept the proposed mandatory measures found in the Second draft of the Driftnet Convention. ${ }^{145}$

\section{The LOS Convention Provisions Regarding Fishing Vessels Navigating Through a Fisheries Zone}

Driftnet fishing vessels are known to have navigated and indeed must navigate through the exclusive economic zones (EEZ) of South Pacific nations to reach the high seas fishing grounds near New Zealand. In addition, support vessels or vessels transporting driftnet catches must also navigate through these zones.

Driftnet fishing vessels have been observed in transit through the New Zealand EEZ on route to fishing grounds in the sub-tropical convergence zone and also within the southern part of the Cook Islands' EEZ. ${ }^{146}$

Coastal States within the South Pacific have sought to ensure that driftnet fishing vessels transiting through their exclusive economic zones are not engaged in any fishing activities, while distant water fishing nations have sought to secure freedom of navigation through these zones.

${ }_{143}$ Driftnet Convention 1989, supra note 12, art. 3(2).

144 See supra notes 16-22.

${ }^{145}$ In correspondence with the Australian Ministry of Foreign Affairs and Trade it was stated that Australia regarded the provision requiring States to prohibit the possession of driftnets onboard fishing vessels as being beyond the bounds of what a coastal State was entitled to regulate at international law. (Correspondence on file with the author). This is somewhat paradoxical as Australia has a provision very similar to this in its own existing fisheries legislation. See Fisheries Act 1952, \& 13AB (Austl.). See also infra notes 307-9 and accompanying text.

${ }^{146}$ See South PaCific COMmission, TWENTY-First Regional TeChNiCAl MEETING ON FishERIES, INFORMATION PAPER 4, SAMPLING OF JAPANESE GILLNETTERS IN NOUMEA, JANUARY-FebRUARY 1989, 3 (1989) [hereinafter SPC 4]; Statement Made by the Royal New Zealand Air Force, N.Z. HERALD, June 24, 1989, at 9. 
Of the previously mentioned measures established in the Driftnet Convention, those prohibiting trans-shipment, processing, transport of driftnet catches, and possession of driftnets may potentially infringe upon the freedom of navigation by fishing vessels through the fishery zones of parties to the Convention. Infringement of freedom of navigation is a matter treated seriously by the international community and may have been a reason why some of the proposed measures in the Driftnet Convention became discretionary rather than mandatory.

Before examining these measures in detail, it is important to review the provisions of the LOS Convention which seek to balance the conflicting exclusive rights of coastal States over their adjacent fishery resources and the rights of distant water fishing nations to navigate their fishing vessels through these waters.

Although the LOS Convention establishes coastal State authority over vessels licensed to fish within a State's exclusive economic zone, it is silent regarding coastal State authority over fishing vessels navigating through the zone. ${ }^{147}$ Despite this silence, the LOS Convention does, through the concept of the exclusive economic zone, endow coastal States with an authority broad enough to justify some regulation over fishing vessels navigating through this zone. ${ }^{148}$

In the territorial sea, however, the LOS Convention does establish measures which coastal States may take regarding the passage of fishing vessels.

For the purposes of examining the rights of navigation of fishing vessels through fisheries zones, the LOS Convention provisions may be divided into those relating to: (1) the territorial sea and archipelagic waters; (2) the exclusive economic zone; and (3) the high seas.

\section{a. The Territorial Sea and Archipelagic Waters}

The LOS Convention provides that " $[t]$ he sovereignty of a coastal State extends, beyond its land territory and internal waters and, in the

147 As noted earlier, Article 62(4) of the LOS Convention provides that a coastal State may prescribe laws and regulations relating to the fishing activities of nationals of other States in the exclusive economic zone. Los Convention 1982, supra note 58, art. 62(4). However, it appears clear from reading Article 62 as a whole that these laws and regulations apply only to vessels actually licensed to fish in the zone and not to vessels navigating through the zone. Id. See also William T. Burke, Exclusive Fisheries Zones and Freedom of Navigation, 20 SAN DIEGo L. REV., 595, 602 (1983) [hereinafter Burke I 1983].

148 Burke I 1983, supra note 147, at 621 . Kwiatkowska argues that "the exact scope of permissible control of the coastal state over unlicensed fishing vessels remains controversial and unresolved in the light of both customary law and the LOS Convention." KWIATKOWSKA, supra note 92 , at 216. 
case of an archipelagic State, its archipelagic waters, to an adjacent belt of sea, described as the territorial sea."149 However, the "sovereignty over the territorial sea is exercised subject to [the LOS] Convention and to other rules of international law."150

Vessels "enjoy the right of innocent passage through the territorial sea," 151 but passage involving "any fishing activities"152 or "any other activity not having a direct bearing on passage" 153 will not be considered innocent. ${ }^{154}$

Furthermore, the coastal State "may adopt laws and regulations . . . relating to innocent passage through the territorial sea, in respect of ... (d) the conservation of the living resources of the sea; and (e) the prevention of infringement of the fisheries laws and regulations of the coastal State." 155

However, the coastal State shall "not hamper the innocent passage of foreign ships through the territorial sea"156 and, in particular, any laws or regulations of the coastal State shall not "impose requirements on foreign ships which have the practical effect of denying or impairing the right of innocent passage."157

Finally the coastal State may "take the necessary steps in its territorial sea to prevent passage which is not innocent."158

Vessels also enjoy the right of innocent passage through archipelagic waters and are generally subject to the same provisions regarding innocent passage as they are in the territorial sea. ${ }^{159}$

It is generally accepted that fishing vessels have the right of inno-

149 LOS Convention 1982, supra note 58, art. 2.

150 Id. art. 2(3).

151 Id. art. 17.

152 Id. art. 19(2)(i).

153 Id.

ist Id. arts. 18, 19.

iss Id. art. 21(1)(d)(e). G.P. Smith suggests that "[p]assage by foreign fishing vessels will be considered innocent if they observe coastal State laws and regulations designed to prevent them from fishing in the territorial sea." G.P. SMITH II, RESTRICTING THE CONCEPT OF FREE SEAS MODERN MARITIME LAW RE-Evaluated 135 (1980).

${ }^{136}$ LOS Convention 1982, supra note 58, art. 24(1).

157 Id. art. 24(1)(a).

1ss Id. art. 25(1).

159 Id. art. 52. The right of innocent passage through archipelagic waters is also subject to the right of the archipelagic State to temporarily suspend passage on security grounds and the rights of third States to archipelagic sealanes passage. See id. arts. 52, 53. For a discussion of innocent passage through archipelagic waters, see D.P. O'CONNELL, THE INTERNATIONAL LAW OF THE SEA, 254-58 (I.A. Shearer ed. 1982); ClIVE R. SYMMONS, THE MARITIME ZONES OF ISLANDS IN INTERNATIONAL LAW, DEVELOPMENTS IN INTERNATIONAL LAW, $71-76$ (1979). 
cent passage through the territorial sea or archipelagic waters (where applicable), but they shall not engage in any fishing activities. ${ }^{160}$ The question thus centers on the meaning of the phrase "any fishing activities" used in Article 19(2)(j) of the LOS Convention. ${ }^{161}$ Should a vessel engage in "any fishing activities" its passage will be considered noninnocent. The phrase "any fishing activities," clearly encompasses activities other than actually fishing, but it is unclear what range of activities would be included. However, a coastal State would seem to have a wide measure of discretion over what it considered to be a fishing activity. ${ }^{162}$ Further interpretative assistance may be obtained from the requirements placed on vessels not to engage in activities not having a direct bearing on passage, or activities incidental to normal modes of continuous and expeditious transit. ${ }^{163}$

Coastal States may also, in their territorial sea and archipelagic waters, prescribe laws and regulations to conserve the living resources of the sea or prevent infringement of their fisheries laws. ${ }^{164}$ In determining whether these laws are justified, a test of their reasonableness would be applied, balancing the international needs for passage against the needs of coastal States to protect their sovereignty over fishery resources. ${ }^{165}$ However, the coastal State should be accorded "a fair amount of

160 See Charles B. Selak, Fishing Vessels and the Principle of Innocent Passage, 48 AM. J. INT'L L. 627, 627 (1954); M.S. MCDOUGAL \& W.T. BURKE, THE PUBLIC ORDER OF THE OCEANS - A CONTEMPORARY INTERNATIONAL LAW OF THE SEA 192-96 (1962).

165 LOS Convention 1982, supra note 58, art. 19(2)(i). This part of Article 19(2)(i) was not present in the Informal Single Negotiating Text, U.N. Doc. A/CONF. 62/WP. 8 of May 7, 1975, in Summary Records of Meetings, Documents, 3rd Session: Geneva, March 17- May 9, 1975 (1975) [hereinafter UNCLOS III ISNT], but did appear in the Revised Single Negotiating Text, U.N. Doc. A/CONF.62/WP.8/Rev.1/Parts I, II, III of May 6, 1976 and U.N. Doc. A/CONF.62/WP.9/Rev.2/Part IV of November 23, 1976, in Summary Records of Meetings, Documents, 4th Session: New York, March 15 - May 7, 1976, at 125 (1976) and in Summary Records of Meetings, Documents, 5th Session: New York, August 2 - September 17, 1976 (1977), [hereinafter UNCLOS III RSNT] and was not modified before the final LOS Convention. However, the UNCLOS III ISNT did contain a clause concerning passage by foreign fishing vessels: "[p]assage of foreign fishing vessels shall not be considered innocent if they do not observe such laws and regulations as the coastal State may make and publish in order to prevent these vessels from fishing in the territorial sea."

${ }_{162}$ See also Geneva Convention on the Territorial Sea and the Contiguous Zone, art. 14(5), 516 U.N.T.S. 205 (1958) [hereinafter Geneva Convention on the Territorial Sea 1958]; R.R. Churchill \& A.V. Lowe, The LAW of THE SEA 66-67 (1983); SMTth, supra note 155, at 37.

163 See LOS Convention 1982, supra note 58, art. 19.

${ }^{164}$ Id. art. 21. See the clause concerning passage by foreign fishing vessels in UNCLOS III ISNT, supra note 161 .

16s See SMTrH, supra note 155, at 38. G.P. Smith suggests that the coastal State should not be allowed to act with whimsy or caprice. The interests it seeks to protect must be important and the substance real, and that passage of the vessel in question must present a substantial risk 
discretion in determining the scope of protection necessary." 166

G.P. Smith observes that whether or not, and on what grounds, "coastal state authorities are entitled to arrest foreign ships that merely traverse territorial waters is an unsettled issue."167 The generally accepted view is that, should a vessel act in contravention of Article 19 or any of the laws established by the coastal State regarding its fishery resources, the vessel is no longer "acknowledged to be exercising a right of innocent passage and it becomes fully subject to the laws of the coastal state. It may, accordingly be boarded, searched and arrested."16s

\section{b. Exclusive Economic Zone}

With regard to the exclusive economic zone, the LOS Convention provides that coastal States have "sovereign rights for the purpose of exploring and exploiting, conserving and managing the natural resources, whether living or non-living," 69 but that in exercising these rights and duties, the coastal State shall have "due regard to the rights and duties of other States," 170 which include "the freedoms . . . of navigation ... and other internationally lawful uses of the sea related to these freedoms, such as those related to the operation of ships . . . ."171 However, these rights enjoyed by third States must in turn be exercised with "due regard to the rights and duties of the coastal State and shall comply with the laws and regulations adopted by the coastal State in accordance with the provisions of this Convention and other rules of international law . . .."172

H.B. Robertson observes that it is "evident that the exclusive economic zone of the 1982 Convention is not a formless concept by which a coastal State has resource competence over a broad zone off its coast, but rather is a zone in which the coastal State has a set of precisely defined rights and duties which mesh on an equal plane with a set of reciprocal rights and duties exercised by other States which carry out activities within the zone." 173 The compromise formula arrived at in the Convention seeks to balance the claims of coastal States to "sover-

to or abridgement of that interest.

166 Id.

167 Id. at 42.

163 Id. See also O'Connell, supra note 159, vol. 1, at 273-74.

${ }^{169}$ LOS Convention 1982, supra note 58, art. 56(1)(a).

170 Id. art. $56(2)$.

171 Id. art. 58(1).

172 Id. art. 58(3).

173 Horace B. Robertson, Jr., Navigation in the Exclusive Economic Zone, 24 VA. J. INT'L L. 864,879 (1984). 
eign rights" over their adjacent fishery resources and the claims of other States to freedom of navigation through these zones. ${ }^{174}$ However, as can be expected, there are contrasting views of where the emphasis should lie when seeking to balance these claims in practice. ${ }^{175}$ Some commentators advocate the balance favoring the coastal State, while others insist upon protecting the rights of other States to freedom of navigation. ${ }^{176}$ The leading principle for determining where the balance should lie in any particular situation is that of the "reasonableness" of the competing claims." "Under proper circumstances, coastal State

134 Id. at $870-80$.

175 See KWIATKOWSKA, supra note 92, at 212 (balancing freedom of navigation with the rights of coastal States).

${ }^{176}$ Elliot Richardson offers a view which emphasizes freedom of navigation:

In the group which negotiated this language it was understood that the freedoms in question, both within and beyond 200 miles, must be "qualitatively and quantitatively the same as the traditional high-seas freedoms recognized by international law." They must be qualitatively the same in the sense that the nature and extent of the right is the same as traditional high-seas freedoms. They must be quantitatively the same in the sense that "the included uses of the sea [must] embrace a range no less complete - and allow for future uses no less inclusive - than traditional high-seas freedoms.

Elliot L. Richardson, Law of the Sea: Navigation and other Traditional National Security Considerations, 19 SAN DIEGo L. Rev. 553, 573 (1982). See also Thomas A. Clingan, Freedom of Navigation in a post UNCLOS III Environment, 46 LAW \& CONTEMP. PROBS. 107, 115 (1983); KWIATKOWSKA, supra note 92, at 214; Richardson, supra, at 574; V. F. Tsarev, The Juridical Nature of the Exclusive Economic Zone and the Legal Regime of Navigation for Foreign Vessels Therein, in THE UN CONVENTION ON THE LAW OF THE SEA: IMPACT AND IMPLEMENTATION,

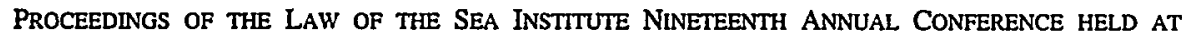
CardifF, Wales, 24-27 July, 1985, at 593 (E.D. Brown \& R.R. Churchill eds., 1987).

The other view interprets the use of the words "sovereign rights" as tilting the balance in favor of the coastal State. E.D. Brown observes that:

[i]t must be said that the balance of principles is weighed heavily in favor of the coastal states. It is a question of sovereign rights exercised with due regard to the rights of other States on the one hand; and on the other hand, of freedoms of navigation, overflight, etc., being enjoyed "subject to the relevant provisions of the present Convention," ... having due regard to the rights of the coastal State and in compliance with the laws and regulations of the coastal State.

E.D. Brown, The Exclusive Economic Zone: Criteria and Machinery for the Resolution of International Conflicts between Users of the EEZ, 4 MARINE POL'Y MGMT. 325, 334 (1977). See also Burke I 1983, supra note 147, at 616-18; W.T. BURKE ET AL., NATIONAL AND INTERNATIONAL LAW ENFORCEMENT IN THE OCEAN 107 (1975); T. Treves, Military Installations, Structures and Devices on the Sea bed, 74 AM. J. INT'L L. 808, 843 (1980).

17 KwIATKOWSKA, supra note 92, at 213-15. It has been observed that this principle will play an increasing role in resolving these types of conflicts over competing uses of the oceans. See O'CONNELL, supra note 159, vol. 1, at 57-58; B. H. Oxman, The Third United Nations Conference on the Law of the Sea: The 1976 New York Sessions, 71 AM. J. INT'L L. 247, 26061 (1977). 
protective measures affecting navigation could be considered reasonable where they are necessary for effective management and enforcement, hold unusual benefit for a particular coastal State or States, and impose slight burdens on navigation." 178 Matters to which regard may be had in considering the reasonableness of any claim by a coastal State to "hamper" navigation would include: whether the measures significantly affected navigation or had only a slight effect; whether the measures added significant time to the voyage or created a hazard for navigation; whether the measures required modification of the vessel (such as carrying transponders); and whether the effect of any measures would deny passage. In addition, the practice of other coastal States in this regard could be significant in justifying any measures taken. ${ }^{179}$

Furthermore, W.T. Burke suggests that where small developing nations, such as those in the South Pacific, ${ }^{180}$ are heavily dependent upon fishery resources, but lack the ability to carry out extensive surveillance and enforcement tasks in their zones, "it is appropriate to allow slight modification of total freedom of movement in order to facilitate effective management. A policy of giving greater weight to coastal ocean resource interests appears justified in these exceptional circumstances where the impacts on navigation are slight and the benefits to the coastal State from improved compliance and enforcement would be unusually large and important." 181

Pursuant to Article 73 of the LOS Convention, coastal States may take measures, including boarding, inspection, arrest, and judicial proceedings, as may be necessary, to ensure compliance with any coastal State laws and regulations regarding the conservation and management of the living resources within their exclusive economic zone. ${ }^{182}$ This authority would appear to extend over fishing vessels navigating through the zone where there was concern held by the coastal State that such vessels were violating its laws and regulations.

Disputes regarding fishing activities within the EEZ are not subject to the dispute settlement procedures established in the LOS Convention. ${ }^{183}$ Although a dispute of this nature could be commenced as a matter concerning freedom of navigation, which would be subject to

178 Burke I 1983, supra note 147, at 615.

179 See id.; Robertson, supra note 173, at 893-95.

180 W.T. Burke mentions the island nations of the Pacific and Indian Oceans and possibly a few West African States as falling into this category. Burke I 1983, supra note 147, at 600 n.14.

181 Burke 1 1983, supra note 147, at 600.

${ }^{182}$ LOS Convention 1982, supra note 58, art. 73.

${ }^{183}$ Id. pt. XV (in particular art. 297(3)). 
these procedures, ${ }^{184}$ a coastal State might refuse to admit to dispute settlement on the grounds that it considered the dispute to be a fisheries matter. ${ }^{185}$

\section{c. High Seas}

With regard to the high seas, the LOS Convention provides that the high seas are open to all States, and all fishing vessels are entitled to freedom of navigation on the high seas, although this freedom is to be exercised under the conditions laid down in the LOS Convention and with due regard for the interests of other States in the exercise of their freedoms. ${ }^{186}$

\section{Mandatory Measures: Articles 2 and 3(1) of the Driftnet Convention}

Articles 2 and 3(1) of the Driftnet Convention establish the mandatory measures which parties to the Convention must implement. ${ }^{187}$ The following section of this article will examine Articles 2 and 3(1) of the Driftnet Convention.

\section{a. Article 2}

Article 2 of the Driftnet Convention provides that: "[e]ach Party undertakes to prohibit its nationals and vessels documented under its laws from engaging in driftnet fishing activities within the Convention Area." 188

It is clear that coastal States may prohibit their nationals and vessels documented under their laws from engaging in driftnet fishing activities within their own fisheries zone. ${ }^{189}$

It is also a well-accepted principle of international law that States

124 Id. art. 297(1)(a). See also KWIATKOWSKA, supra note 92, at 224.

18s Kwiatkowska states that "compulsory settlement might not apply to disputes concerning the freedom of navigation of foreign unlicensed fishing and research vessels." KWIATKOWSKA, supra note 92, at 225 .

125 LOS Convention 1982, supra note 58, art. 87.

187 Driftnet Convention 1989, supra note 12, arts. 2, 3(1). See also supra notes 133-37 and accompanying text.

128 Driftnet Convention 1989, supra note 12, art. 2.

isg This is an accepted principle of customary international law. See William T. Burke, The Law of the Sea Convention Provisions on Conditions of Access to Fisheries Subject to National Jurisdiction, 63 OR. L. REV. 73 (1984); O'CONNELL, supra note 159. 
have extra-territorial jurisdiction over their nationals and those vessels which fly their flag entitling States to prohibit their nationals and vessels from engaging in activities outside their territory. ${ }^{190}$ With regard to Article 2 of the Driftnet Convention, I.V. Shearer observes that:

[t]he obligation of Parties to legislate with respect to their own nationals, and vessels documented under their laws, is well founded in international law on the nationality principle of jurisdiction. It is also the basis of the [LOS Convention], Art. 117 which engages the responsibility of States to legislate with respect to their own nationals to adopt measures for the conservation of the living resources of the high seas. ${ }^{191}$

The phrase "vessels documented under its laws" used in the Driftnet Convention appears to have been taken from an Article in the U.S. Tuna Treaty, ${ }^{192}$ which itself appears to be based upon the term as used in the United States. ${ }^{193}$

Of those nations which have implemented the Driftnet Convention in the South Pacific, Australia ${ }^{194}$ and the Cook Islands ${ }^{195}$ have prohibited their nationals or vessels from driftnet fishing both within their fishery zones and in all areas outside their fisheries zones (which, presumably, includes areas beyond the Convention Area), while New Zealand has followed the requirement in the Convention and only prohibits its nationals and vessels from driftnet fishing within its own fishery zone and in the Driftnet Convention Area. ${ }^{196}$ The Tokelau legislation only prohibits foreign fishing vessels from using or possessing driftnets while within its fishery zone. ${ }^{197}$ It makes no mention of the use or possession of driftnets by Tokelauans. ${ }^{198}$

190 For a discussion of this principle, see IAN BROWNLIE, THE PRINCIPLES OF PUBLIC INTERNATIONAL LAW 296 (1973); D.J. HARRIS, CASES AND MATERIALS ON INTERNATIONAL LAW 21112 (3rd ed. 1983); LOS Convention 1982, supra note 58, arts. 91-94, 97; O'CONNELL, supra note 159, vol. 2, at 733-90; D.P. O'CONNELL, INTERNATIONAL LAW 604-11, 670-92 (2nd ed. 1970) [hereinafter O'CONNELL 1970]; GEORGE SCHWARZENBERGER, INTERNATIONAL LAW 188.89 (1957); Smith, supra note 113, at 147-66.

191 Shearer, supra note 15 , at 237.

192 U.S. Tuna Treaty 1987, supra note 96, art. 1.1(d).

193 The term "documented under the laws of the United States" means "registered, enrolled, or licensed under the laws of the United States." 46 U.S.C. $\$ 801$. See also The Helori, 24 F.2d 710, 711 (W.D. Wash. 1928).

194 Fisheries Management Act, 1991, § 13 (Austl.).

195 Marine Resources Act, 1989, $\& 15$ (Cook Islands).

196 Driftnet Prohibition Act, 1991, § 5 (N.Z.).

197 Tokelau (Exclusive Economic Zone) Fishing Regulations 1988, Amendment No. 1 (SR 1989/268), §§ 3, 13B, 13C (N.Z.).

${ }^{198}$ Id. 
In view of the global moratorium on driftnet fishing recommended by the United Nations, ${ }^{199}$ the approach taken by Australia and the Cook Islands, prohibiting their nationals and vessels from engaging in driftnet fishing entirely, seems a useful one to adopt. Furthermore, taking stricter measures than those required is expressly permitted by the Driftnet Convention. ${ }^{200}$

\section{b. Article 3(1)}

Article 3(1) of the Driftnet Convention is divided into two parts. ${ }^{201}$ Article $3(1)(a)$ obliges parties, generally neither to assist nor encourage the use of driftnets within the Convention Area. Article 3(1)(b) obliges parties to take specific measures, consistent with international law, to restrict driftnet fishing activities within the Convention Area including, but not limited to, prohibiting the use of driftnets within areas under a party's fisheries jurisdiction and prohibiting trans-shipment of driftnet catches within areas under a party's jurisdiction. ${ }^{202}$

\section{(i). Fisheries Jurisdiction/Area Jurisdiction}

There appears to be a deliberate distinction made in the drafting of Article 3(1)(b) between areas under a party's "fisheries jurisdiction" and areas under a party's "jurisdiction." 203 This interpretation is further reenforced by the use of the word "jurisdiction" as opposed to "fisheries jurisdiction" in Article $3(2)(b)$ - relating to the prohibition of processing $^{204}$ and use of the word territory in Article 3(2)(a) - relating to the landing of catches. ${ }^{205}$

The meaning of the word territory appears to include both land territory and ports. However, it is difficult to discern the precise meaning of the word "jurisdiction" and the term "fisheries jurisdiction." A possible interpretation is that the term "fisheries jurisdiction" would include internal waters, archipelagic waters (if applicable), the territorial sea, and the exclusive economic zone (or fisheries zone).

One interpretation of the word "jurisdiction" is that it includes areas

159 UNGA Resolution 44/225, supra note 13.

200 Driftnet Convention 1989, supra note 12, art. 3(3).

201 Id. app. 2, art. 3(1).

202 Id. art. 3(1)(b).

203 See Shearer, supra note 15, at 251-52.

20 Although here the word jurisdiction is used in conjunction with the word "facilities," suggesting facilities on land. Driftnet Convention 1989, supra note 12, art. 3(2)(b).

${ }^{203}$ Id. art. 3(2)(a). 
under a party's fisheries jurisdiction as well as ports and roadsteads. ${ }^{206}$ In addition, the word "jurisdiction" may also be referring to a State's extra-territorial jurisdiction over nationals and vessels. ${ }^{207}$ This would be particularly relevant to Article $3(2)(\mathrm{b})$, where parties are invited to prohibit the processing of driftnet catches in facilities under their jurisdiction which might include vessels flying the flag of that party. ${ }^{208}$

An alternative interpretation is that the word "jurisdiction" does not encompass the fisheries jurisdiction of a party, but refers only to areas within a party's land territory as well as ports.

Despite the clear distinction made in the drafting, doubt has been raised as to whether there is in fact a deliberate distinction between these words or whether it is an oversight. ${ }^{209}$

(ii). Mandatory Obligations of Article 3(1)

The following section of this article will examine the four sets of mandatory obligations contained in Article 3(1): (a) not to assist or encourage the use of driftnets within the Convention Area; (b) to take measures, consistent with international law, to restrict driftnet fishing activities within the Convention Area; (c) to prohibit the use of driftnets within areas under a party's fisheries jurisdiction; and (d) to prohibit the trans-shipment of driftnet catches within areas under a party's jurisdiction.

\section{(a). Not to Assist or Encourage the Use of Driftnets}

Article $3(1)(a)$ is a general and all-encompassing obligation. ${ }^{210}$ It acts as a "umbrella" under which are found the more specific obligations contained in Article 3(1)(b). ${ }^{211}$ A similar phrase is also used in the SPNFZ Treaty 1985 and the use of the phrase in the Driftnet Con-

206 I.A. Shearer argues, with regard to trans-shipment, that the word "jurisdiction" may also encompass the contiguous zone. Shearer suggests that a coastal State may be able to prohibit trans-shipment as infringing its customs laws. However, it is clear that the contiguous zone does not relate to fisheries jurisdiction. See Shearer, supra note 15, at 253; W.E. MASTERTON, JURISDiction in Marginal SEAS (1929); P.C. Jessup, THE LAW OF TERritorial Waters and MarITIME JURISDICTION: THE NATURE AND EXTENT OF CIVIL AND CRIMINAL JURISDICTION IN MARGINAL SEAS (1927); Shigeru Oda, The Concept of the Contiguous Zone, 11 INT'L \& COMP. L.Q. 131 (1962); A.V. Lowe, The Development of the Concept of the Contiguous Zone 52 BRIISH Y.B. INT'L L. $109^{\circ}$ (1982).

207 See supra note 190.

208 Driftnet Convention 1989, supra note 12, art. 3(2)(b).

209 Correspondence between I.A. Shearer and the author (Oct. 17, 1991) (on file with the author).

210 Driftnet Convention 1989, supra note 12, art. 3(1)(a).

211 Id. art. 3(1)(b). 
vention may have had its origins there. ${ }^{212}$ Article $3(1)$ (a) requires parties to not assist nor encourage the use of driftnets within the Convention Area. The Article would appear to include not only physical assistance or encouragement, but also that of a political or economic nature.

\section{(b). Restrict Driftnet Fishing Activities}

The first part of Article 3(1)(b) of the Driftnet Convention requires that each Party undertake "to take measures consistent with international law to restrict driftnet fishing activities within the Convention $\mathrm{Ar}$ ea...."213

This obligation, to restrict driftnet fishing activities, extends to the entire Convention Area which includes, not only the fisheries waters of the parties, but also those high seas areas within the Convention Area and relates to nationals, national fishing vessels, and foreign fishing vessels. Note, however, that the word "restrict" has been used here rather than the word "prohibit," thus placing less of an obligation on the parties.

The Driftnet Convention lists a wide range of activities as "driftnet fishing activities" including: the actual or attempted catching, taking, or harvesting of fish with the use of a driftnet; any support operations such as searching for or locating fish (including operations of placing, searching for, or recovering fish-aggregating devices or associated electronic equipment such as radio beacons); transporting, trans-shipping, or processing any catch; or supplying provisions to driftnet vessels (including the use of aircraft). ${ }^{214}$

The following sub-section of this Article will examine the provisions relating to the actual or attempted catching, taking, or harvesting of fish; searching for or locating fish; and fishery-support operations (including refueling and re-provisioning). With regard to transporting, transshipping, or processing any catch, these matters will be discussed later.

\section{Harvesting Fish}

As previously mentioned, coastal States are clearly able to restrict (and in fact prohibit, should they desire) the actual or attempted catching, taking, or harvesting of fish within their fishery zones. ${ }^{215}$ Coastal States may also restrict or prohibit their nationals and national vessels from engaging in these activities outside of their fishery zones in accor-

\footnotetext{
212 See SPNFZ Treaty 1985, supra note 11, arts. 3(c), 6(b), 7(1)(c).

213 Driftnet Convention 1989, supra note 12, art. 3(1)(b).

214 Id. art. 1(c).

215 See supra note 189 and accompanying text.
} 
dance with the principle of extra-territorial jurisdiction. ${ }^{216}$ Clearly, however, coastal States have no exclusive jurisdiction over the harvesting of fish by foreign fishing vessels on the high seas areas within the Convention Area. ${ }^{217}$

\section{Searching/Locating Fish}

Activities such as searching for or locating fish (including operations of placing, searching for, or recovering fish-aggregating devices or associated electronic equipment such as radio beacons) are closely associated with fishing itself and may properly be defined as fishing activities. ${ }^{218}$

It is clear that international law provides for coastal States to regulate fishing and its associated activities undertaken by its own nationals or vessels and by licensed foreign fishing vessels within areas under its fisheries jurisdiction. ${ }^{219}$ Coastal States also have jurisdiction to regulate or prohibit their nationals and vessels from carrying out these activities outside their fishery zones under the principle of extra-territorial jurisdiction. ${ }^{220}$

Furthermore, it is the customary practice of many coastal States to prohibit or restrict foreign vessels from searching for or locating fish within their exclusive economic zone unless licensed. ${ }^{221}$ However,

216 See supra note 190.

217 Coastal States have shared jurisdiction over straddling stocks and highly migratory species with States fishing for these species on the high seas. See LOS Convention, supra note 58, arts. 63(2), 64. See also William T. Burke, Highly Migratory Species in the New Law of the Sea 14 OCEAN DEV. \& INT'L L. 273 (1984) [hereinafter Burke 1984]; William T. Burke, Fishing in the Bering Sea Donut: Straddling Stocks and the New International Law of Fisheries 16 ECOLOGY L. Q. 285 (1989) [hereinafter Burke 1989]; DAHMANI, supra note 92, at 61; FAO Leg. Study 47, supra note 77; KWIATKOWSKA, supra note 92.

218 FAO REGIONAL COMPENDIUM, supra note 127 , at 11 n.37, n.38.

So far as the definition of the fishing activity itself is concerned, the recent tendency seems to be to characterize the placing or retrieval of fish aggregating devices as fishing, in view of the important role that these devices now play in new tuna fishing techniques ... Considerable discussion has taken place in the [South Pacific] region as to whether or not to include searching for fish as part of the act of fishing. The definition of fishing in the New Zealand Fisheries Act would appear to cover searching for fish by including in the definition 'any operation in support of or in preparation for Id. any activities described in this definition ...."

219 See supra note 189. See also LOS Convention 1982, supra note 58, art. 62; Shearer. supra note 15, at 252 .

20 See HARRIS, supra note 190.

221 See Moore, supra note 126, at 164-69; 1 FAO REGIONAL COMPENDIUM, supra note 127. at 11-14. For examples of legislation see: Coastal Fisheries Protection Act 1953, (as amended) § 
coastal States do not have exclusive jurisdiction over these activities if undertaken by foreign fishing vessels on the high seas within the Convention Area.

Of those nations which have implemented the Driftnet Convention in the South Pacific, Australia, the Cook Islands, and New Zealand have prohibited their nationals and vessels, and foreign fishing vessels from engaging in fishing activities associated with driftnet fishing within their fishery zones. ${ }^{222}$ However, Australia ${ }^{223}$ and the Cook Islands ${ }^{224}$ also prohibit their nationals or vessels from engaging in fishing activities associated with driftnet fishing in all areas outside their fisheries zones, while New Zealand has followed the requirement in the Driftnet Convention and only prohibited its nationals and vessels from engaging in driftnet fishing activities within the Convention Area. ${ }^{225}$ The Tokelau driftnet legislation does not address these activities.

\section{Refueling/Re-provisioning}

The refueling and re-provisioning of driftnet vessels may occur through support vessels visiting the ports of a coastal State to collect provisions to then take back out to sea (this activity will be examined later when dealing with port access), or may occur at sea independent of access to a coastal State's ports. Here the question is whether such refueling or re-provisioning can be prohibited or restricted within waters under a coastal State's fisheries jurisdiction or on the high seas.

It is accepted at international law that coastal States may prohibit their nationals and vessels which fly their flag from engaging in these activities. ${ }^{226}$

Foreign vessels engaged in refueling and re-provisioning fishing vessels are considered to be engaged in "fishing activities." A coastal State may prohibit foreign vessels from engaging in these activities in its internal waters, archipelagic waters, territorial sea, and exclusive economic zone.

Furthermore, it is the customary practice of many coastal States to prohibit or restrict foreign vessels from refueling or re-provisioning other

3(2)(a) and (d) (Can.); The Fisheries Act 1977, § 20(2)(b) (Gam.); Fisheries Ordinance 1977, (as amended), $\S 5$ (Kiribati); Fisheries Act 1972, $\S 7$ (b) (Solom. Is.); Tuvalu Fisheries Ordinance 1978, \& 5; The Fisheries Act, 1982, § 4 (Vanuatu).

22 Fisheries Management Act, 1991, \& 13 (Austl.); Marine Resources Act 1989, § 15 (Cook Islands); Driftnet Prohibition Act, 1991, § 4 (N.Z.).

23 Fisheries Management Act, 1991, §§ 13(2)-13(4) (Austl.).

24 Marine Resources Act, 1989, § 15 (Cook Islands).

223 Driftnet Prohibition Act, 1991, \& 5 (N.Z.).

226 See HARRIS, supra note 190. 
fishing vessels within their exclusive economic zone, ${ }^{227}$ although an exception should be afforded to vessels which, through exhaustion of fuel or provisions, are in distress. ${ }^{228}$ However, coastal States do not have exclusive jurisdiction over these activities if undertaken by foreign vessels on the high seas.

Of those nations which have implemented the Driftnet Convention in the South Pacific, Australia, the Cook Islands, and New Zealand prohibit their nationals, vessels, and any other person from providing food, fuel, or other supplies to any vessel equipped for or engaged in driftnet fishing within waters under their fisheries jurisdiction. ${ }^{229}$ The New Zealand legislation has been drafted very precisely ${ }^{230}$ and includes an exception for "the supply of such food, fuel, and other goods and services as is necessary to enable a vessel to proceed safely and directly to a port outside New Zealand."231 Australia ${ }^{232}$ and the Cook Islands ${ }^{233}$ also prohibit their nationals or vessels from providing these services in all areas outside their fisheries zones, while New Zealand only prohibits this within the Convention Area. ${ }^{234}$ The Tokelau driftnet legislation does not address these activities. ${ }^{235}$

227 FAO REgIONAL COMPENDIUM, supra note 127, at 11 n.36. Many coastal States provide explicitly for the prohibition of unlicensed operations within their fishery zones to refuel or reprovision other vessels. See, e.g., Fisheries (Regulation of Foreign Fishing Boats) Act, 1979, §§ 4, 28 (Sri Lanka):

4. Subject to the provisions of section 12, no foreign fishing boat shall be used for fishing or related activities in Sri Lanka waters except under the authority of a permit issued under section 6 .

28. "related activities" in relation to fishing means -

(c) refueling or supplying fishing boats or performing other activities in support of, or ancillary to, fishing operations.

See also Coastal Fisheries Protection Act 1953 (as amended), § 3(2)(a) and (d) (Can.); Fisheries Ordinance 1977 (as amended), $\S$ 5(d) (Kiribati); Territorial Sea and Exclusive Economic Zone Act, 1977, \& 14 (N.Z.); Fisheries Act 1972, \& 7(d) (Solom. Is.); Tuvalu Fisheries Ordinance 1978, § 5(d); The Fisheries Act. 1982, $\S 82$ and 4 (Vanuatu); Fishery Conservation and Management Act 1976, Public Law 94-265, $\S 201$ and 3(10) (U.S.).

${ }^{228}$ See The Alliance, U.N. Rep., Vol. IX, 140 (1903). This case involved a vessel seeking entry to a port because of exhaustion of fuel. See also O'CONNELI, supra note 159, vol. 2, at 856-58.

29 Fisheries Management Act, 1991, § 13 (Austl.); Marine Resources Act 1989, § 15 (Cook Islands); Driftnet Prohibition Act, 1991, § 11 (N.Z.).

230 Driftnet Prohibition Act, 1991, § 11 (N.Z.).

231 Id. § 11(5).

232 Fisheries Management Act, 1991, §§ 13(2)-13(4) (Austl.).

233 Marine Resources Act, 1989, § 15 (Cook Islands).

234 Driftnet Prohibition Act, 1991, \& 11 (N.Z.).

235 Tokelau (Exclusive Economic Zone) Fishing Regulations 1988, Amendment No. 1, (SR 1989/268) (N.Z.). 


\section{(c). The Use of Driftnets Within Areas Under a Party's Fisheries} Jurisdiction

The term "use of driftnets" employed in Article 3(1)(b) may be interpreted variously. ${ }^{236}$ The word "use" can be interpreted narrowly to mean only those activities involved in actually deploying driftnets and closely associated activities, or it could be interpreted widely to include almost any fishing or associated activity where driftnets are the gear type employed. It would appear that a narrow interpretation is more appropriate. $^{237}$

The "use of driftnets" would certainly include setting and hauling in of driftnet and the actual or attempted catching, taking, or harvesting of fish with a driftnet. The term may also include support operations, such as searching for or locating fish. Taking a narrow interpretation, the term would not extend, for example, to trans-shipping or transporting driftnet catches.

It is clear that international law provides for coastal States to regulate fishing and the type of fishing gear used within areas under their fisheries jurisdiction. ${ }^{238}$ This entitles coastal States to prohibit the use of a specific gear type, such as driftnets and any associated fishing activities by any of its nationals or vessels or licensed foreign fishing vessels.

Of those nations which have implemented the Driftnet Convention in the South Pacific, Australia, the Cook Islands, and New Zealand have prohibited their nationals, national fishing vessels, and foreign fishing vessels from engaging in any "driftnet fishing activities" within their fishery zones, rather than prohibiting the "use of driftnets." however, has made it a general condition of licenses granted to foreign fishing vessels that they do not "use a driftnet" for fishing while in the Tokelau exclusive economic zone. ${ }^{240}$

226 Driftnet Convention 1989, supra note 12, art. 3(1)(b)(i).

237 The reason for taking a narrow interpretation is to avoid including within the word "use" many of the activities which are discretionary, such as possessing driftnets. However, a difficulty with taking a narrow interpretation of the word "use" in this context is that the word "use" is also employed in Article 3(1)(a) which seems to require a wide interpretation of that word.

${ }^{233}$ See Shearer, supra note 15, at 252. See also supra note 189.

239 Fisheries Management Act, 1991, § 13 (Austl); Marine Resources Act, 1989, § 15 (Cook Islands); Driftnet Prohibition Act, 1991, $\S 8$ and 5 (N.Z.).

${ }^{240}$ Tokelau (Exclusive Economic Zone) Fishing Regulations 1988, Amendment No. 1, (SR 1989/268), \& 3 (N.Z.). 


\section{(d). Trans-shipment of Driftnet Catches}

The South Pacific nations and territories decided to prohibit transshipment of driftnet catches through their ports at the first informal consultation held on driftnet fishing in $1988 .{ }^{241}$

Trans-shipment is not defined in the Driftnet Convention, but is generally considered, for the purposes of fisheries management, to be the transfer for further transportation of fish or fish products from one vessel to another vessel or facility. ${ }^{242}$ In this respect, it may be considered a fishing activity. ${ }^{243}$

Article 3(1)(b)(ii) obliges parties to prohibit the transhipment of driftnet catches within areas under their "jurisdiction."244. As previously mentioned, this would appear to include areas under a party's fisheries jurisdiction as well as their ports and territory. ${ }^{245}$

It is accepted that a State may prohibit trans-shipment of fish or fish products in its territory, ports, internal waters, archipelagic waters, and territorial sea. ${ }^{246}$ I.A. Shearer has argued that in the contiguous zone the coastal State could prohibit trans-shipment as it would be related to the coastal State's customs jurisdiction. ${ }^{247}$ In the exclusive eco-

241 See FFA First Consultation, supra note 6.

242 The Cook Islands legislation defines "transshipping" as "transferring any fish or fish products to or from any vessel." Marine Resources Act 1989, \& 2 (Cook Islands).

${ }^{243}$ Some States define fishing as "fishing" and "related activities." Very often the definition of "related activities" includes trans-shipping. See, e.g., Marine Resources Act 1989, $\S 2$ (Cook Islands); Fisheries (Regulation of Foreign Fishing Boats) Act, 1979, $\S 4$ and 28 (Sri Lanka); Marine Resources Act 1978, §§ 2 and 4 (Nauru); Fisheries Act, 1982, § 2 and 4(1) (Vanuatu).

Many States also define "fishing" to include any operation at sea in connection with actual fishing, which presumably would include trans-shipping at sea. See, e.g., Marine Boundaries and Jurisdiction Act, 1978, § 2 (Barb.); Marine Spaces Act, 1977, § 2 (Fiji); Marine Boundaries Act, 1978, § 2 (Gren.); Maritime Boundaries Act, 1977, § 2 (Guy.); Territorial Sea and Exclusive Economic Zone Act, 1977, § 2 (N.Z.); Tokelau (Territorial Sea and Exclusive Economic Zone) Act 1977, $\& 2$ (N.Z.); Territorial Sea and Exclusive Economic Zone Act 1977, $\$ 2$ (Tonga).

244 Driftnet Convention 1989, supra note 12, art. 3(1)(b)(ii).

${ }^{245}$ See supra notes 203-9 and accompanying main text.

245 It seems clear that transhipping would be considered a "fishing activity" and, if carried out in the territorial sea, would be a breach of innocent passage under Article 19 and in particular Article 19(2)(i) of the LOS Convention. LOS Convention 1982, supra note 58, art. 19. In addition, under Article 21 of the LOS Convention, a coastal State may adopt laws and regulations in respect of the conservation of the living resources of the sea and the prevention of infringement of the fisheries laws and regulations of the coastal State, which would also permit a coastal State to prohibit trans-shipment in its territorial sea and archipelagic waters. Id. art. 21.

I.A. Shearer argues that "in the territorial sea the necessary stopping would deprive the voyage of its character as innocent passage ... [The coastal State] could certainly legislate to prohibit such activities in its ports." Shearer, supra note 15, at 253.

${ }^{247}$ Shearer, supra note 15 , at 253 . For a discussion of the concept of the contiguous zone, 
nomic zone, however, both I.A. Shearer and C. Mizukami have argued that a prohibition on trans-shipment is "problematic" in terms of international law. ${ }^{248}$

I.A. Shearer has stated that: "[i]n its EEZ . . . there seems no warrant in international law for such a prohibition. Transshipment is not an activity mentioned in [the LOS Convention], Article 62(4) as within the power of law or regulation-making of a coastal State in its EEZ, even though that list of powers is preceded by the familiarly expansive phrase 'inter alia." "249

However, as previously mentioned and with respect to I.A. Shearer, Article 62(4) provides coastal States with authority over vessels whose purpose is licensed fishing in the EEZ rather than navigation. ${ }^{250}$ In addition, several commentators have stated, with regard to Article 62(4), that the list of regulations and conditions is meant to be illustrative, rather than exhaustive, of the regulatory powers of the coastal State over vessels licensed to fish within the zone. ${ }^{251}$

The trans-shipment of catches does constitute an activity closely associated with fishing and thus is able to be prohibited by the coastal State in accordance with its general conservation and management authority over the living resources of the exclusive economic zone. Coastal States would be wary of any fishing vessel trans-shipping its catch to another vessel within its fishery zone. The catch may have been taken

see MASTERTON, supra note 206; JeSSUP, supra note 206; Oda, supra note 206; Lowe, supra note 206. It is clear that fishing activities are not able to be regulated by a coastal State under the regime of the contiguous zone, although a prohibition on trans-shipment in the contiguous zone might be entertained if a coastal State considers this necessary to prevent infringement of its customs laws and regulations within its territory or territorial sea.

248 See Mizukami, supra note 15, at 120; Shearer, supra note 15, at 253.

Mizukami has stated that:

[a]mong the regulations in this convention, some of the prohibitions are problematic in terms of international law. For example, the prohibition of trans-shipment of driftnet catches within areas under its jurisdiction may be contrary to the freedom of navigation on the high seas or Article 58(1) of the United Nations Convention on the Law of the Sea, which guarantees freedom of navigation, subject to the relevant provisions of the convention.

Mizukami, supra note 15 , at 120.

249 Shearer, supra note 15 , at 253.

250 See supra note 189.

251 See DAVID ATTARD, THE EXClusive ECONOMIC ZONE IN INTERNATIONAL LAW 172 (1987); William T. Burke, Unifed States Fishery Management, 76 AM. J. INT'L L. 24, 38 n.42 (1982) (however, it is unclear whether Burke is referring to Article 62(3) or 62(4) or both here); DahmanI, supra note 92, at 82; W. C. EXTAVOUR, THE EXClusive ECONOMIC ZONE - A STUDY OF THE EVOLUTION AND PROGRESSIVE DEVELOPMENT OF THE INTERNATIONAL LAW OF THE SEA 194 (1979) (Geneva: Institut Universitaire de Hautes Études Internationales); Moore, supra note 126, at 163 . 
inside the zone and through trans-shipment be in the process of transport out of the zone without record. A prohibition of trans-shipment within a coastal State's fisheries zone will not affect legitimate navigation through the zone. If the fish are being caught on the high seas, it would be usual to trans-ship in that area or in a port if trans-shipment was to occur at all.

Furthermore, it is the customary practice of many coastal States to prohibit or restrict the trans-shipment of catches within their fisheries zones between vessels not licensed to fish or even between a vessel licensed to fish and another which is unlicensed. ${ }^{252}$ This practice of coastal States, taken under the general authority afforded to them by the LOS Convention, appears to be attaining the quality of customary international law.

Of those nations which have implemented the Driftnet Convention in the South Pacific, Australia, the Cook Islands, New Zealand, and Tokelau prohibit the trans-shipment of driftnet catches inside waters under their fisheries jurisdiction. ${ }^{253}$ However, Australiaa ${ }^{254}$ and the Cook Islands, ${ }^{255}$ because of the way their legislation has been drafted, also prohibit their nationals or national vessels from trans-shipping any driftnet catch in all areas outside their fisheries zones, while New Zealand only prohibits its nationals and national vessels from trans-shipping driftnet catches inside the Convention Area. ${ }^{256}$ The Tokelau legislation does not apply to its own nationals. 257

252 Coastal States often explicitly prohibit trans-shipment within their exclusive economic zone. See, e.g., Exclusive Economic Zone (Foreign Fishing Craft) Regulations 1978 (SR 1978/63), § 34 (N.Z.):

34. Trans-shipment of catch - (1) No fish shall be trans-shipped from a foreign fishing craft in New Zealand fisheries waters to any other craft, except at a place and time authorised for the purpose by the Director-General, and in accordance with such conditions (if any) as he may specify.

See also Fisheries Act 1952, § 13(1)(d) (Austl.); Coastal Fisheries Protection Act 1953, § 3(2)(b) (Can.); Marine Spaces (Foreign Fishing Vessels) Regulations 1979, § 31 (Fiji); The Fisheries Act 1977, § 20(2)(b) (Gam.); Fisheries Ordinance 1977, § 5(1)(c) (Kiribati); Fisheries Act 1974, § 15 (Papua N.G.); Fisheries Act 1972, 7(c) (Solom. Is.); Fisheries Ordinance (CAP 45) Fisheries (Foreign Fishing Vessel) Regulations 1982, § 15 (Tuvalu).

${ }^{253}$ Fisheries Management Act, 1991, § 13 (Austl.); Marine Resources Act 1989, § 15 (Cook Islands); Driftnet Prohibition Act, 1991, \& 7 (N.Z.); Tokelau (Exclusive Economic Zone) Fishing Regulations 1988, Amendment No. 1, (SR 1989/268), \& 13A (N.Z.).

254 Fisheries Management Act, 1991, \$§ 13(2)-13(4) (Austl.).

2ss Marine Resources Act, 1989, § 15 (Cook Islands).

256 Driftnet Prohibition Act, 1991, \& 7 (N.Z.).

257 Tokelau (Exclusive Economic Zone) Fishing Regulations 1988, Amendment No. 1, (SR 1989/268) (N.Z.). 
4. Discretionary Measures: Articles 3(2) and 3(3)

Article $3(2)$ and $3(3)$ of the Driftnet Convention establishes the discretionary measures parties may implement. ${ }^{258}$

Under Article 3(2) each party is invited to take measures, consistent with international law, to prohibit the landing of driftnet catches within their territory, prohibit the processing of driftnet catches in facilities under their jurisdiction, prohibit the importation of any fish or fish product which was caught using a driftnet, restrict port access and port servicing facilities to driftnet vessels and prohibit the possession of driftnets on board any vessel within areas under their fisheries jurisdiction.

Article 3(3) provides that nothing in the Convention shall prevent a party from taking measures against driftnet fishing activities which are stricter than those required by the Convention.

The following section of this Article will examine the measures contained in Articles 3(2) and 3(3), but in a slightly altered order. It will begin with an examination of (a) the landing of driftnet catches and (b) the processing of driftnet catches. This will then be followed by an examination of two measures: (c) the transporting of driftnet catches and (d) the possession of a driftnet, both of which may, if implemented strictly, be inconsistent with the rights to navigation through areas under the fisheries jurisdiction of a party. This will then be followed by an examination of the measures inviting parties to (e) restrict port access, (f) prohibit the importation of fish caught using driftnets and (g) take measures which are stricter than those required by the Convention.

\section{a. Landing of Driftnet Catches}

The South Pacific nations and territories decided to embargo the landing of driftnet-caught albacore tuna in their ports and canneries at the first informal consultation on driftnet fishing, held in $1988 .{ }^{259}$ Article $3(2)$ (a) of the Driftnet Convention affirms that decision and invites parties to "prohibit the landing of driftnet catches within [their] territory."260

Coastal States have sovereign jurisdiction within their territory and there seems no doubt that they may prohibit the landing of driftnet catches. The use of the word "territory" would appear to include ports.

FFA First Consultation, supra note 6, at 5.

260 Driftnet Convention 1989, supra note 12, art. 3(2)(a). 
With regard to State practice, many coastal States require that vessels licensed to fish within their fishery zones actually land their catch in the coastal States' ports ${ }^{261}$ while others prohibit the landing of catches taken outside their zone in their ports. ${ }^{262}$

Of those nations which have implemented the Driftnet Convention in the South Pacific, only New Zealand explicitly prohibits the landing of driftnet catches in its territory. ${ }^{263}$ However, the general licensing provisions of the Australian and Cook Islands fisheries legislation require that a vessel hold a license before landing any catch taken outside their fishery zones and presumably a license to land driftnet-caught fish would be denied. ${ }^{264}$ In addition, the New Zealand legislation does not specify that the prohibition on landing of driftnet-caught fish relates only to fish caught in the Convention Area and, therefore, could apply to the landing of driftnet-caught fish from anywhere. ${ }^{265}$

Article 3(2)(a) is clear in its intention and it is difficult to imagine any difficulties with regard to its implementation. It seems unfortunate that it is not a mandatory requirement under the Driftnet Convention, rather than being a discretionary one.

\section{b. Processing of Driftnet Catches}

Article $3(2)$ (b) of the Driftnet Convention provides that a party may "prohibit the processing of driftnet catches in facilities under its jurisdiction."266

Although the processing of driftnet catches is included specifically within Article 3(2)(b), it also appears within the definition of "driftnet

261 See, e.g., Marine Boundaries and Jurisdiction Act 1978, § 12 (Barb.); Marine Spaces Act, 1977, § 14 (Fiji); Decree Law No. 921, Art. 4 (Hond.); Presidential Proclamation, February 1979, Schedule, $\S 2$ (Kenya); Territorial Sea and Exclusive Economic Zone Act, 1977, § 15 (N.Z.).

Article 62(4)(h) of the LOS Convention specifically lists "the landing of all or any part of the catch by such vessels in the ports of the coastal State" as one of the laws and regulations which a coastal State may establish. LOS Convention 1982, supra note 58, art. 62(4)(h). Although the provision appears to be intended more for coastal States to require the landing of catches, it is reasonable to infer support from this Article for the proposition that coastal States are entitled to prevent any landing of catches.

262 See, e.g., Coastal Fisheries Protection Act 1953, § 3(2)(b) (Can.); The Fisheries Act 1977. $\S 20$ (2)(b) (Gam.); Federal Act on Fisheries Development, Diario Oficial, No. 20, 1972, $\S$ 78(XX) (Mex.); Fisheries Ordinance 1977, (as amended), $\S 5$ (Kiribati); Fisheries Act 1972, § 7 (Solom. Is.); Tuvalu Fisheries Ordinance 1978, § 5.

263 Driftnet Prohibition Act, 1991, § 8 (N.Z.).

264 Fisheries Act 1952, § 13BA(1) (Austl.); Marine Resources Act 1989, § 12 (Cook Islands).

${ }^{265}$ Driftnet Prohibition Act, 1991, \& 8 (N.Z.) (although there were no other driftnet fishing activities occurring near New Zealand).

${ }^{266}$ Driftnet Convention 1989, supra note 12, art. 3(2)(b). 
fishing activities" included in Article 1(c) and thus also comes within the scope of Article 3(1)(b) which requires parties (being a mandatory requirement) to take measures to restrict driftnet fishing activities. ${ }^{267}$

The term "processing of driftnet catches" is not defined in the Convention, but is generally considered to be the operation of selecting fish from a catch, retaining the fish whole or gutting, filleting, or otherwise manufacturing a product from the fish, packaging, freezing, and discarding any waste. ${ }^{268}$ The processing of catches is generally considered to be a fishing activity. Although processing usually takes place on land, it is sometimes undertaken at sea, either aboard the fishing vessel itself or aboard a factory vessel after trans-shipment.

Article 3(2)(b) appears to be directed primarily at prohibiting the processing of driftnet catches in facilities on land or in ports although the term "facilities under its jurisdiction" could include facilities aboard a party's own vessels. ${ }^{269}$

It is accepted that a State may prohibit fishing activities (which would include the processing of catches) within its land territory and its ports, internal waters, archipelagic waters, and territorial sea. It might also be argued that "in the contiguous zone the control could be argued to be related to the coastal State's customs jurisdiction."270

With regard to the exclusive economic zone, a question arises where a vessel in transit through the exclusive economic zone engages in processing a catch taken outside the zone. In these circumstances, the rights of the coastal State to regulate fishing must be weighed against the rights to freedom of navigation. It would seem that a prohibition on the processing of a catch while a vessel is navigating through the EEZ will not hamper navigation, but will provide some security for the coastal State that fish is not being caught in the EEZ and then processed into another product before being able to be identified.

It is the practice of some coastal States to prohibit or restrict the processing of fish catches by unlicensed foreign vessels within their exclusive economic zone. ${ }^{271}$

207 Id. arts. 1(c), 3(1)(b). See supra note 214 and accompanying text.

${ }^{26 s}$ See, e.g., the definition in the Fisheries Act 1977, $\$ 2$ (Gam.) ("processing" in relation to fish includes cleaning, filleting, icing, freezing, canning, salting, smoking, cooking, pickling, drying, or othervise preserving or preparing fish by any method).

269 See supra note 189.

270 Shearer, supra note 15 , at 253-54. For discussion of the concept of the contiguous zone, see supra note 206.

271 See, e.g., Fisheries Act 1952, § 13B (Austl.); Marine Spaces Act, 1977, §§ 16, 2 (Fiji); Marine Resources Act 1978, §§ 2, 4 (Nauru); Territorial Sea and Exclusive Economic Zone Act 1977, §§ 2, 14 (N.Z.); Fisheries Act 1974, § 15 (Papua N.G.); Fisheries (Regulation of Foreign 
Of those nations which have implemented the Driftnet Convention in the South Pacific, only New Zealand explicitly prohibits the processing of driftnet catches, but limits this to processing catches within its land territory. ${ }^{272}$ However, Australia, the Cook Islands, and New Zealand all prohibit their nationals and national vessels from engaging in "driftnet fishing activities" within, and beyond their fishery zones, which appears to include processing any driftnet catches. ${ }^{273}$ In addition, all three nations prohibit any person (which would include the masters of foreign fishing vessels) from engaging in driftnet fishing activities within their fishery zones, which therefore includes a prohibition on any person processing driftnet catches within these zones. ${ }^{274}$ The Tokelau legislation does not address the issue of processing of driftnet catches.

\section{c. Transporting any Driftnet Catch}

Article 3(1)(b) of the Driftnet Convention, as previously mentioned, requires that each party "take measures consistent with international law to restrict driftnet fishing activities within the Convention Area."275 The Convention lists a wide range of activities as "driftnet fishing activities" including "transporting . . a any driftnet catch . . ."276 Consequently, there is a requirement that each party take measures, consistent with international law, to restrict transporting of any driftnet catch within the Convention Area.

It is accepted as international law that a State may prohibit the transport of catches of fish through areas under its sovereignty, such as its land territory, its ports, and internal waters. ${ }^{277}$ However, where a vessel transporting a driftnet catch is merely in transit through a coastal State's territorial seas, archipelagic waters, or exclusive economic zone, it is also clear that the coastal State cannot prohibit the navigation of that vessel. ${ }^{278}$ The transport of fish caught with driftnets through these waters would be an exercise of freedom of navigation unless the trans-

Fishing Boats) Act, 1979, $\S \S 4,28$ (Sri Lanka); Territorial Sea and Exclusive Economic Zone Act, 1978, §§ 2, 13 (Tonga).

272 Driftnet Prohibition Act, 1991, § 9 (N.Z.).

273 Fisheries Management Act, 1991, § 13 (Austl.); Marine Resources Act 1989, § 15 (Cook Islands); Driftnet Prohibition Act 1991, \$§ 3, 4, 5 (N.Z.). New Zealand's prohibition applies to New Zealand fisheries waters and to the Convention Area, but not beyond that. Id. $\S \S 4,5$.

274 Fisheries Management Act, 1991, § 13 (Austl.); Marine Resources Act 1989, \& 15 (Cook Islands); Driftnet Prohibition Act 1991, § 3, 4 (N.Z.).

${ }_{n \text { s }}$ Driftnet Convention 1989, supra note 12, art. 3(1)(b).

276 Id. art. 1(c).

277 See supra note 189.

278 See supra notes $146-86$. 
port of the catch involved any procedure or activity which could be described as a fishing activity.

Although it is the practice of many coastal States to provide within their national legislation for a prohibition or restriction on foreign fishing vessels transporting fish catches within the exclusive economic zone, unless authorized to do so, ${ }^{279}$ a careful examination of this legislation indicates that the prohibitions and restrictions are directed at the transporting of fish actually caught within the exclusive economic zone. ${ }^{280}$

However, coastal States, seeking to ensure that fish being transported through their fishery zone were actually caught outside the zone, have authority to board and inspect vessels in their zone and if it is reasonable to believe that the fish have been caught within the zone, or that the vessel has engaged in any fishing activities while in the zone, to arrest it. ${ }^{28 I}$ However, if, upon inspection, it is clear that the fish were caught outside the zone and that the vessel is only navigating through the zone, it must be left to continue on its way. ${ }^{282}$

Australia, the Cook Islands, and New Zealand include in their definition of driftnet fishing activities "transportation" of any driftnet catch. ${ }^{283}$ These three nations thus prohibit their nationals and vessels from engaging in any driftnet fishing activities within their fishery zones and beyond, which includes transporting any driftnet catch. ${ }^{284}$ In addition, all three prohibit any person (which would include the master of a foreign vessel) from engaging in driftnet fishing activities within their fishery zones, which includes transporting any driftnet catches. ${ }^{285}$

279 See, e.g., Fisheries Act 1952, § 13B (Austl.); Marine Resources Act 1978, $\S \S 2,4$ (Nauru); Territorial Sea and Exclusive Economic Zone Act 1977, §§ 2, 14 (N.Z.); Fisheries Act 1974, § 15 (Papua N.G.); Fisheries (Regulation of Foreign Fishing Boats) Act, 1979, §§ 4, 28 (Sri Lanka); Territorial Sea and Exclusive Economic Zone Act, 1978, §§ 2, 13 (Tonga).

250 See, e.g., Territorial Sea and Exclusive Economic Zone Act, No. 28, 1977, §§ 2, 14 (N.Z.):

14. Prohibition of operation of unauthorised foreign fishing craft in zone -

No foreign fishing craft shall be used for fishing within the exclusive economic zone except in accordance with a license issued by the Minister under section 15 of this Act in respect of that fishing craft.

2. "Fishing" means .... (inter alia) any activity involving the ... transportation ... of any fish; ....

${ }^{281}$ LOS Convention 1982, supra note 58, art. 73.

282 See supra notes $146-86$.

283 Fisheries Management Act, 1991, § 13(5) (Austl.); Marine Resources Act 1989, § 2 (Cook Islands); Driftnet Prohibition Act, 1991, \& 3 (N.Z.).

${ }_{224}$ Fisheries Management Act, 1991, § 13 (Austl.); Marine Resources Act 1989, § 15 (Cook Islands); Driftnet Prohibition Act 1991, $\S \$ 3,4,5$ (N.Z.). New Zealand's prohibition applies to New Zealand fisheries waters and to the Convention Area, but not beyond that. Id.

${ }^{285}$ Fisheries Management Act, 1991, § 13 (Austl.); Marine Resources Act 1989, § 15 (Cook 
Tokelau does not restrict this activity. ${ }^{286}$

A strict interpretation of this legislation would appear to infringe the rights of other States to freedom of navigation through the fishery zones of Australia, the Cook Islands, and New Zealand. ${ }^{287}$ As mentioned previously, however, this restriction may only be intended to be applied if the catch was also taken within the fishery zones of these parties. ${ }^{288}$

In addition, New Zealand also explicitly prohibits its nationals and vessels from transporting any driftnet catch in the Convention Area and also explicitly prohibits any person or vessel from transporting any driftnet catch within New Zealand fisheries waters. ${ }^{289}$ However, the New Zealand legislation also provides for a defense if the defendant did not know the catch was taken with driftnets, or if the fish was preserved in containers in another country. ${ }^{290}$ This defense, however, does not appear to apply to a foreign fishing vessel which is transporting its catch, taken on the high seas, through New Zealand's fishery zone to another country. ${ }^{291}$ Enforcement of this provision, in this situation, would appear to be contrary to international law.

\section{d. Possession of a Driftnet}

Article 3(2)(e) of the Driftnet Convention invites parties to take measures, consistent with international law, to "prohibit the possession of driftnets onboard any fishing vessel within areas under its fisheries jurisdiction. ${ }^{~} 292$ A question arises over whether implementation of this Article is consistent with the principle of freedom of navigation.

What is the effect of this Article should a driftnet fishing vessel, in

Islands); Driftnet Prohibition Act 1991, § 3, 4 (N.Z.).

${ }^{286}$ Tokelau (Exclusive Economic Zone) Fishing Regulations 1988, Amendment No. 1, (SR 1989/268) (N.Z.).

287 The Cook Island's legislation provides a defense. Unlicensed fishing vessels are permitted to enter Cook Islands fishery waters if it is for a purpose recognized by international law (such as transporting a catch of fish). The Australian Fisheries Act 1952 also provides a defense where the vessel is in transit. See Marine Resources Act 1989, §§ 12, 58 (Cook Islands); Fisheries Act 1952, § 13AB (Austl.).

283 See supra note 283.

289 Driftnet Prohibition Act, 1991, \& 7 (N.Z.).

250 Id. $\& 28$.

291 Id.

292 In the second draft of the Driftnet Convention, the mandatory measures extended to prohibiting the possession of driftnets onboard any fishing vessel within areas under a party's fisheries jurisdiction. See Driftnet Convention - Second Draft 1989, supra note 18, art. 4. See also supra notes $18,151$. 
"possession of driftnets," pass from an area of high seas into the exclusive economic zone of a party on its way to another area of high seas? Could a party prohibit the possession of the driftnet while the vessel was navigating through areas under the coastal State's fisheries jurisdiction?

Is this Article to apply only to national vessels? The Article states that the prohibition of the possession of driftnets is onboard "any fishing vessel," indicating that it should also apply to foreign fishing vessels. ${ }^{293}$

It is interesting to note that the United States, the United Kingdom, and France, which are all States having strong interests in securing freedom of navigation, have signed this Convention, presumably understanding the significance of this Article. However, they may have also been influential in shifting this Article from the mandatory list of measures in the second draft of the Driftnet Convention to the discretionary list in the final version of the Driftnet Convention. ${ }^{294}$

The issue of "possession of a driftnet" was also raised at the meeting held in June 1989. The French Polynesian delegate to that meeting urged "all concerned nations to go beyond the measures already taken and to ban not only the use, but also the possession of driftnets in all boats passing through the EEZ's."295 I.A. Shearer has this to say with regard to this provision:

[d]oubts can be raised against the validity of the Convention's optional prohibition against "the possession of drift nets on board any fishing vessel within areas under [a Party's] fisheries jurisdiction," at least in so far as it might be applied in the enforcing State's EEZ. The [LOS Convention], Article 62(4)(c) empowers a coastal State to prescribe the use in its EEZ of types of gear, but it is not at all clear, on the basis of the wording employed, that mere possession of certain types of gear, properly stowed, could be prohibited. The doubts deepen where a State might seek to enforce such a prohibition against a foreign fishing vessel exercising its rights of archipelagic sea lanes passage or transit passage through straits. One can only assume, or at least hope, that in applying the measures indicated by the Convention "consistent with international law," the Parties would not attempt to apply them to ves-

293 Initially the New Zealand ban on the possession of driftnets was to apply only to New Zealand vessels. Press Statement, Ministers of Environment, External Relations and Trade, Fisheries, Foreign Affairs, Defence, and Conservation (May 24, 1989). However, this was almost immediately extended to cover foreign fishing vessels. See New Zealand Regulations on driftnet fishing, supra notes 64-65 and accompanying text.

294 See supra note 145.

$20 s$ Statement of French Polynesia, 1989 First Meeting, supra note 6. 
sels exercising the rights of archipelagic sea lanes passage or transit passage through straits, which seem completely contrary to both the Law of the Sea Convention and customary international law. ${ }^{296}$

Article 3(2)(e) invites parties to prohibit the possession of driftnets onboard any fishing vessel "within areas under its fisheries jurisdiction." 297 These areas would include internal waters, the territorial sea, archipelagic waters, and the exclusive economic zone (or fishery zone). Within each of these areas there also exist different rules relating to rights of passage.

Within its internal waters, a coastal State would be entitled by international law to prohibit the passage of vessels (whether they were in possession of driftnets or not). ${ }^{298}$

In the territorial sea and archipelagic waters, the regime of innocent passage applies. ${ }^{29}$ The mere possession of a driftnet does not, in this author's opinion, have the requisite quality to be defined as a fishing activity. Any law or regulation passed by a coastal State under Article 21 of the LOS Convention which prohibited mere possession of a driftnet would go beyond the authority afforded to coastal States in this Article. ${ }^{300}$ Furthermore, such a requirement would impose on foreign fishing vessels a condition which would have the practical effect of denying, impairing, or hampering the right of innocent passage and thus would be contrary to Article 24 of the LOS Convention. ${ }^{301}$ However, it would appear that under Article 21, a coastal State could require foreign fishing vessels passing through the territorial sea to stow their fishing gear in a manner which would not enable it to be used. ${ }^{302}$

Within the exclusive economic zone, coastal States have sovereign rights over the living resources, including the right to prevent foreign fishing vessels navigating through the zone from fishing. ${ }^{303}$ However, this right must be balanced against the rights of foreign fishing vessels to navigate through the EEZ or fishery zone. In determining where the

206 Shearer, supra note 15 , at $253-54$.

397 Driftnet Convention 1989, supra note 12, art. 3(2)(e).

${ }^{298}$ Except in a situation where the establishment of straight baselines have enclosed previously unenclosed waters. Here the regime of innocent passage applies. See LOS Convention 1982. supra note 58 , art. 8.

299 See id. pt. II, § 3(A).

300 Id. art. 21.

301 Id. art. 24.

302 Id. art. 21. See also Article 42, which provides that States bordering straits used for international navigation may require foreign fishing vessels passing through the strait to stow their fishing gear. Id. art 42.

${ }^{303}$ See supra notes $169-85$ and accompanying text. 
balance should lie, the purpose, effect, and reasonableness of the measures taken must be assessed. In addition, the special situation of States such as the small island nations and territories of the South Pacific may be taken into account. ${ }^{304}$

In this author's opinion, should a foreign fishing vessel, in possession of driftnets, but with gear properly stowed simply pass directly through a fishery zone, the balance must fall in favor of navigation by that vessel. Any laws or regulations which hampered or denied passage of the vessel simply because it possessed a driftnet would, therefore, be contrary to international law.

Although not expressly permitted by the LOS Convention, it has become the customary practice of coastal States to require fishing vessels in transit through their fishery zones to stow their fishing gear so that it cannot be used. ${ }^{305}$ The extent of State practice is this regard would suggest that this requirement has attained the quality of customary international law. ${ }^{306}$

A legislative mechanism used in Australia may indicate how Article 3(2)(e) was intended to be implemented and enforced. ${ }^{307}$ In Australia a

304 See the arguments of William T. Burke, supra notes 180-81 and accompanying text.

3os The requirement of passing foreign fishing vessels to stow their gear is being encouraged in national legislation throughout the South Pacific:

Almost all of the countries of the region now include provisions in their national legislation requiring foreign fishing vessels not authorized to fish to stow their fishing gear while in the fisheries waters .... Most countries that have recently revised their legislation now follow the model provisions agreed upon in the Suva harmonisation workshop, which specify the general criteria that the gear should not be readily available for use for fishing.

1 FAO REgIONAL COMPENDIUM, supra note 127, at 25. See Fisheries Act 1952, § 13AB (Austl.); Coastal Fisheries Protection Regulations - 1976 (SOR/76-803), \& 15 (Can.); Marine Resources Act 1989, § 12(4) (Cook Islands); Marine Spaces (Foreign Fishing Vessel) Regulations 1979, § 30 (Fiji); The Fisheries Act 1977, § 20 (Gam.); Fisheries Ordinance 1977, § 5(6) (Kiribati); Exclusive Economic Zone (Foreign Fishing Craft) Regulations 1978 (SR 1978/63), § 32 (N.Z.); Fisheries Act 1974, § 15 (Papua N.G.); Control of Foreign Fishing Vessels Decree, 1979, \& 4 (Sey.); Fisheries Act 1972, \& 7 (Solom. Is.); Fisheries (Regulation of Foreign Fishing Boats) Act, 1979, \& 5 (Sri Lanka); Tuvalu Fisheries Ordinance, 1978, § 5(6); Fisheries Act. 1982, § 5 (Vanuatu); Fishery Limits Act 1976, \& 2(4) (U.K.).

306 FAO REgIONAL COMPENDIUM, supra note 127, at 32; Moore, supra note 126, at 176 n.107; Shearer, supra note 15 , at 253-54. This is a requirement for transit passage through straits. See LOS Convention 1982, supra note 58, art. 42(1)(c).

307 Fisheries Act 1952, \& 13AB (Austl.):

(1) A person shall not, in the Australian fishing zone, have in his possession or in his charge a foreign boat equipped with nets, traps or other equipment for taking, catching or capturing fish.

(1A) A person who contravenes sub-section (1) is guilty of an offence ... (3) It is a defence to a prosecution for an offence against sub-section (1) if a person charged satisfies the court that, at the time of the alleged offence - 
presumption is established whereby it is an offense to possess on board a fishing vessel fishing gear while the vessel is within the Australian fishery zone. ${ }^{303}$ The presumption, however, may be rebutted if the fishing gear is securely stowed and the vessel is shown to be only transiting the zone. ${ }^{309}$

Of the nations which have implemented the Driftnet Convention in the South Pacific, only New Zealand and Tokelau have prohibited vessels from possessing driftnets. ${ }^{310}$ While the Cook Islands legislation does not prohibit the possession of driftnets, it does require proper stowage of fishing gear for vessels not licensed to fish within its zone. ${ }^{311}$ Australia does not intend to legislate specifically to prohibit the possession of driftnets, but the legislation just mentioned will continue to apply. ${ }^{312}$

Section 6 of the New Zealand Driftnet Prohibition Act states categorically: No vessel in New Zealand fisheries waters shall have onboard any driftnet.

However, there is also a clear defense provided in section 28 . If the defendant "satisfies the Court that the vessel was not otherwise equipped to take fish or marine life with the use of a driftnet" then the defendant is excused. ${ }^{313}$ However, this defense is not entirely clear in its intent. Must the defendant merely satisfy the Court that the gear was stowed or secured so that it was unable to be used while the vessel was in the EEZ or is the requirement greater than that? The burden of proving the defense is on the defendant and prior to satisfying the Court of his or

(a) the nets, traps or other equipment for taking, catching or capturing fish were stowed and secured; and

(b) the boat was travelling through the Australian fishing zone ... (iii) from a point outside the Australian fishing zone to another point outside the Australian fishing zone by the shortest practicable route ...."

300 Id.

309 Id.

310 Driftnet Prohibition Act, 1991, § 6 (N.Z.); Tokelau (Exclusive Economic Zone) Fishing Regulations 1988, Amendment No. 1, (SR 1989/268), §§ 3, 13B, 13C (N.Z:).

311 The Cook Islands Marine Resources Act 1989 requires: "[a]ll fishing gear onboard any foreign fishing vessel in any place in the fisheries waters where it is not permitted to fish shall be stowed in such manner as it shall not be readily available for fishing or as may be prescribed." Marine Resources Act 1989, § 12(4) (Cook Islands).

312 Correspondence between the Australian Department of Foreign Affairs and Trade and the author (Dec. 4, 1991) (on file with the Australian Department of Foreign Affairs and Trade, Sea Law and Ocean Policy 736/13/5/6).

313 Driftnet Prohibition Act, 1991, \& 28 (N.Z.). 
her innocence, presumably the defendant would have been arrested and the vessel, fish, and gear seized. This in itself would entail a severe infringement of the right to freedom of navigation and there would have to be clear evidence that the defendant was or had been fishing inside the EEZ before an arrest on grounds of mere possession of a driftnet was made.

The Tokelau legislation makes no provision for a defense and simply states that "[n]o foreign fishing craft in the exclusive economic zone [or the territorial sea] shall have any driftnet onboard that craft." ${ }^{314} \mathrm{Al}-$ though this legislation may be interpreted as a licensing condition for foreign fishing vessels fishing in the Tokelau fishery zone, other provisions of the Tokelau legislation vitiate this interpretation. ${ }^{315}$ It would appear that if this legislation were enforced it would be infringing rights of freedom of navigation.

\section{e. Restricting Port Access}

The driftnet fishing vessels operating in the South Pacific had their home ports in the North Pacific and one way in which their activities in the South Pacific could be curtailed, or at least made very difficult, was to restrict or prohibit their access to ports and port-servicing facilities throughout the region, not only for landing their catches, but also for reprovisioning and refueling.

This action was one agreed upon by the nations and territories of the South Pacific very quickly after the driftnet fishing issue arose. ${ }^{316}$ However, the ability of driftnet fishing vessels to trans-ship their catch, be re-provisioned, and refueled at sea required the nations and territories of the South Pacific to extend the prohibition to factory ships (those vessels to which catches are trans-shipped at sea which then process or land the catches) and support vessels (those vessels which re-provision and refuel fishing vessels at sea). ${ }^{317}$

An incident which occurred in New Zealand at the end of January 1990 involving the refuelling vessel "We Carrier" highlighted the diffi-

314 Tokelau (Exclusive Economic Zone) Fishing Regulations 1988, Amendment No. 1, (SR 1989/268), § 13B and 13C (N.Z.).

315 Section 3 of the Tokelau legislation actually makes it a condition of licenses that "no driftnet may be onboard the craft while the craft is within the exclusive economic zone." Tokelau (Exclusive Economic Zone) Fishing Regulations 1988, Amendment No. 1, (SR 1989/268), § 3 (N.Z.).

315 FFA First Consultation, supra note 6, at 5.

317 Judith Swan, High Seas Southern Albacore Driftnet Fishery, 142 (paper prepared for the British Columbia Driftnet Conference, July 17-19, 1989 - on file with the South Pacific Forum Fisheries Agency). 
culty of clearly identifying these support vessels and obtaining evidence of their activities. ${ }^{318}$ It is an indisputable fact that driftnet fishing vessels were refuelled and re-provisioned at sea making the denial of port access to these types of support vessels very important. ${ }^{319}$

Article $3(2)(d)$ of the Driftnet Convention deals with port access. It invites parties to, consistent with international law, "restrict port access and port servicing facilities for driftnet fishing vessels." 320

There are two parts to Article 3(2)(d). Parties may restrict either port access and/or port servicing facilities. Restricting the use of port servicing facilities would no doubt deter driftnet vessels from entering ports and would overcome any policy difficulties a coastal State may have over actually closing its ports to foreign vessels. ${ }^{321}$ Article 3(2)(d) requires access of any "driftnet fishing vessel" to be restricted, but the term "driftnet fishing vessel" is not defined in the Convention. Although the term "fishing vessel" is defined, ${ }^{322}$ it does not clearly include reprovisioning or other support vessels. ${ }^{323}$ Although it is unfortunate that the Convention does not clearly restrict port access or port servicing facilities to re-provisioning and refuelling support vessels, a wide inter-

318 See Press Release, New Zealand Prime Minister, (January 30, 1990); Hampton et al., supra note 4; TME, March 19, 1990, at 42-43 (International Edition).

319 Press Release, supra note 318.

320 Driftnet Convention 1989, supra note 12 , art. 3(2)(d). It is interesting to note that the second draft of the Driftnet Convention had mandatory provisions relating to port access and servicing. It required parties to "deny" access, whereas the Driftnet Convention itself only requires parties to "restrict" access. The New Zealand draft of the Driftnet Convention includes an exception permitting port access where a vessel is in distress. The Driftnet Convention - New Zealand Draft requires parties to: "[deny] port access and port servicing facilities to driftnet fishing vessels except in cases of distress." This exception, for vessels in distress, has not been explicitly included in the final version of the Driftnet Convention, but perhaps the term "restrict" is used here to allow for this exception. See supra notes 17, 18, infra notes 341-42 and accompanying text.

${ }^{321}$ During the initial stages of the driftnet issue, the New Zealand Govemment had wanted to maintain an "open port" position and had not wanted to close its ports to driftnet fishing vessels. During the Second Informal Consultation, held in March 1989, it was noted that the New Zealand delegate stated that "New Zealand has an open port policy." See FFA Second Consultation. supra note 6.

322 Driftnet Convention 1989, supra note 12, art. 1(e). See supra notes 125-32 and accompanying text.

323 However, despite this difficulty, other articles of the Driftnet Convention offer a basis for parties to restrict the access of re-provisioning and other support vessels. Article 3(1)(b) requires parties to take measures to restrict driftnet fishing activities, while Article 3(3) allows parties to take measures against driftnet fishing activities which are stricter than those required by the Convention. The term "driftnet fishing activities" includes "cooperation in the provision of food, fuel and other supplies for vessels equipped for or engaged in driftnet fishing." Driftnet Convention 1989, supra note 12 , arts. $3(1)(\mathrm{b}), 1$ (c)(vi). 
pretation of the term "driftnet fishing vessel" would include these types of vessels. ${ }^{324}$

A review of international opinion would suggest that nations are able to restrict or prohibit vessels from entering ports. ${ }^{325}$ In addition, nations are considered able to deny port servicing facilities. ${ }^{326} \mathrm{Howev}-$ er, coastal States should give sufficient notice of the fact of closure to other nations who may be affected. ${ }^{327}$

State practice in recent centuries affords no indication that states may demand access to ports of other states as a matter of right. Claims to deny access to merchant vessels do not occur with great frequency in peacetime, but when they are made, as they still sometimes are, they are very seldom even controverted by an opposing claim to entry as a right conferred by international law. ${ }^{328}$

However, this customary right to restrict or prohibit vessels is subject to any treaty obligations entered into by the various parties and the duty upon nations to admit into their ports vessels in distress. ${ }^{329}$

The Convention on the Regime of Maritime Ports and annexed Statute on the International Regime of Maritime Ports ${ }^{330}$ is a multilateral treaty providing for access of foreign vessels to maritime ports. ${ }^{331}$

324 Perhaps a better way to have drafted Article 3(2)(d) to include this restriction, would have been to state that each Party may also take measures consistent with international law to: "(d) restrict port access and port servicing facilities to vessels engaged in or likely to be engaged in any driftnet fishing activities."

32s See A.V. Lowe, The Right of Entry into Maritime Ports in International Law, 14 SAN DiEgo L. Rev. 597 (1977); BROWNLIE, supra note 190, at 276; MCDOUgal \& BURKE, supra note 160, at 103-14 (particularly at 107 n.48); O'CoNNELL, supra note 159, vol. 2, at 847-49.

However, there are also those who believe ports must be open. For a review of these authors and arguments, see Lowe, supra note 325 , at 597 . In particular, see C. JOHN COLOMBOS, INTERNATIONAL LAW OF THE SEA 175-77 (6th ed. 1967).

326 See Lowe, supra note 325 , at 616 . Lowe states that there are a number of cases where vessels are permitted to enter ports, but are then denied the use of port facilities. In most cases, in which the use of facilities was denied, the denial was based on security grounds or solely on political considerations. Id.

37 Id. at 608.

328 MCDOUGAL \& BURKE, supra note 160, at 105-6.

329 See Lowe, supra note 325 , at 610; MCDOUGAL \& BURKE, supra note 160 , at 110,110 n.59.

330 Statute on the Intemational Regime of Maritime Ports, annexed to the Convention on the Regime of Maritime Ports, Dec. 9, 1923, 28 L.N.T.S 115 [hereinafter Regime of Maritime Ports]. 331 Id. art 2:

Subject to the principle of reciprocity and to the reservation set out in the first paragraph of Article 8, every Contracting State undertakes to grant the vessels of every other Contracting State equality of treatment with its own vessels, or those of any other State whatsoever, in the maritime ports situat- 
Australia, Fiji, New Zealand, France, and Japan are all parties to this Convention. ${ }^{332}$

Although the Convention has been relied upon as support for a rule of international law that the ports of a State must be open to foreign ships, ${ }^{333}$ a more accurate description of the Convention is that it "aims at eliminating discrimination in respect of access to ports, rather than to proclaim a universal and abstract right of access." ${ }^{334}$ Article 2 of the Convention provides that "every Contracting State undertakes to grant the vessels of every other Contracting State equality of treatment with its own vessels ... as regards freedom of access to [its] port[s]."335 However, this Convention states that it explicitly does not "in any way apply to fishing vessels or to their catches." ${ }^{336}$

Provision for access to ports is also commonly made in bilateral agreements between States, in particular in treaties of friendship, commerce, and navigation, ${ }^{337}$ but "these agreements do not necessarily im-

ed under its sovereignty or authority, as regards freedom of access to the port, the use of the port, and the full enjoyment of the benefits as regards navigation and commercial operations which it affords to vessels, their cargoes and passengers.

332 Australia, Fiji, New Zealand, France, and Japan became Parties to this Convention on June 29, 1925, March 15, 1972, April 1, 1925, August 2, 1932, and September 30, 1926, respectively.

${ }^{333}$ The Convention was relied upon primarily by the Arbitrator in Saudi Arabia v. Aramco, who stated that: "[a]ccording to a great principle of public international law, the ports of every state must be open to foreign merchant vessels and can only be closed when the vital interests of the State so require." Saudi Arabia v. Aramco 27 I.L.R. 117, 212 (1963).

344 O'CONNELL, supra note 159, vol. 2, at 848. See also Lowe, supra note 325, at 604-6.

335 Regime of Maritime Ports, supra note 330, art. 2.

${ }^{336}$ Id. art. 14. However, a question again arises as to whether support vessels are included within the term "fishing vessel" used in this Convention or whether the term "fishing vessel" applies only to those vessels which catch fish. In the author's opinion, the term applies to fishing vessels, factory ships, vessels landing catches, and other support or re-provisioning vessels. This relies on a broad view of the Regime of Maritime Ports Convention, which, in the author's opinion, is designed to enhance commercial interaction and not fishing activities.

337 See, e.g., Treaty of Friendship, Commerce and Navigation between the United States of America and the Federal Republic of Germany, Oct. 29, 1954, 273 U.N.T.S. 3 thereinafter Treaty of Friendship US/Germany 1954]. Article 5 of that Agreement states that "[t]he provisions of the present Article shall not apply to fishing vessels." See also Herman Walker, Jr., Modern Treaties of Friendship, Commerce and Navigation, 42 MINN. L. Rev. 805 (1958).

Although somewhat different, see also Agreement on Trade and Economic and Technical Cooperation, Apr. 20, 1976, N.Z.-Korea, N.Z.T.S. 1976, No. 10 thereinafter Agreement on Trade NZ/Korea 1976]:

1. Each Government agrees that the nationality of merchant vessels registered in the territory of the other Government shall be recognized, when such vessels are in its ports, upon presentation of documents and certificates is- 
pose restrictions on coastal [State] competence to refuse access to ports. ${ }^{\text {"338 }}$ In addition, it is common to exclude fishing vessels and the landing of their catches from the provisions of these agreements. ${ }^{339}$

Some coastal nations explicitly deny port access to fishing vessels unless they are authorized to enter their ports. ${ }^{340}$ However, nations are required, on humanitarian grounds, to admit entry of vessels in distress. ${ }^{341}$ The use of the word "restrict" instead of "prohibit" in Article $3(2)(d)$ of the Driftnet Convention suggests that an exception for vessels in distress is provided for. ${ }^{342}$

Thus it would appear that fishing vessels may be prohibited from entering ports, or if permitted to enter, may be denied the ability to land their catches or access port servicing facilities. This would also apply to vessels used to refuel or re-provision other fishing vessels.

Neither Australia, the Cook Islands, nor Tokelau explicitly prohibit or restrict port access or port servicing facilities to driftnet fishing vessels or support vessels in their legislation implementing the Driftnet Convention. ${ }^{343}$ By contrast, the New Zealand legislation does prohibit driftnet fishing vessels and support vessels from entering the ports of New Zealand. ${ }^{34}$

sued by the competent authorities in conformity with the legislation in force in the other country, and that such vessels, together with their masters, crew and cargoes, shall be accorded treatment in the use of ports and of their facilities equal to that accorded to merchant vessels registered in any other foreign country.

2. The provisions of this Article will not apply to coastal shipping, pilotage, towing and similar services, and, without the prior approval of the other Government, the off-loading or transhipment of catches by the fishing vessels of either country.

339 MCDOUGAL \& BURKE, supra note 160 , at 109.

339 Id. at 110 n.59. See supra notes 336, 337.

340 See, e.g., Fisheries Act 1952, § 13BA (Austl.).

341 See supra note 329.

$3+2$ See also supra note 17.

3.13 Fisheries Management Act, 1991, § 13 (Austl.); Marine Resources Act, 1989 (Cook Islands): Tokelau (Exclusive Economic Zone) Fishing Regulations 1988, Amendment No. 1, (SR 1989/268) (N.Z.). However, the general fisheries legislation of these nations and territories would seem to require a fishing vessel to be licensed before entering their ports. Fisheries Act 1952, § 13BA (Austl.); Marine Resources Act, 1989, § 12 (Cook Islands); Tokelau Territorial Sea and Exclusive Economic Zone Act 1977, § 6 (N.Z.).

34 Driftnet Prohibition Act, 1991, $\S \S 10,12$ (N.Z.). Section 10 states that no foreign vessel shall enter the internal waters of New Zealand that has "onboard any driftnet, or is otherwise equipped for driftnet fishing" or has "within the preceding 3 months been engaged in driftnet fishing (whether within or outside New Zealand fisheries waters or the Convention Area)." Id. $\S$ 10. 


\section{f. Importation of Fish Caught Using a Driftnet}

Article $3(2)(c)$ of the Driftnet Convention invites parties to: "prohibit the importation of any fish or fish product, whether processed or not, which was caught using a driftnet."

One of the main difficulties for parties implementing this provision will be proving whether or not a fish or fish product, particularly once it has been processed, was caught with a driftnet.

When considering a prohibition on the importation of fish caught by driftnets, the Papua New Guinea Law Reform Commission felt there was no guarantee and no simple way of determining that fish canned in other countries (for example, Singapore or Korea) and labelled "driftnet free," had not in fact been caught with driftnets. ${ }^{345}$ Although the Commission considered it possible to implement a prohibition and then place the onus upon the importer to prove the fish were not caught with driftnets, the prohibition would have been largely unenforceable. ${ }^{346}$ The New Zealand Government, while actively supporting other measures taken to prohibit driftnet fishing, also felt that a prohibition on the importation of fish caught with driftnets or requiring labelling of canned

The second part of section 10 appears to prohibit the entry of a vessel which in the recent past has been engaged in driftnet fishing, but which is currently not so engaged or equipped. However, it is unclear why the time limit of 3 months is used (although the intention may be to prohibit entry of those vessels engaged in the North Pacific driftnet fishery). It may prove very difficult to discern whether a vessel has in fact been driftnet fishing within the preceding 3 months unless it had been detected through surveillance or some record kept of its activities. Some kind of international information sharing between differing surveillance and enforcement authorities seems essential if this type of restriction is to be imposed.

Section 10 also prohibits entry to any vessel which has been driftnet fishing "whether within or outside New Zealand fisheries waters or the Convention Area." This presumably includes all other oceans and seas. (It may have been drafted in this fashion to specifically include driftnet fishing vessels operating in the North Pacific or perhaps Indian Oceans). Again enforcement of this requirement will be difficult.

Section 12 of the New Zealand legislation grants power to the Director-General of Fisheries to direct any vessel not to enter the internal waters of New Zealand or, if it has entered the internal waters of New Zealand, to leave those waters, where the Director-General has reasonable grounds to believe that it "[h]as onboard any driftnet, or is otherwise equipped for driftnet fishing" or "[h]as within the preceding 3 months been engaged in driftnet fishing (whether within or outside New Zealand fisheries waters or the Convention Area)" or that the vessel "is to be used to supply any food, fuel, or other goods or services acquired or to be acquired in New Zealand to any vessel engaged or to be engaged in driftnet fishing in New Zealand fisheries waters or the Convention Area." Id. § 12. However vessels may enter or remain in New Zealand ports for purposes of obtaining food, fuel, and other goods and services necessary to enable them to proceed safely and directly to a port outside New Zealand.

345 STEWART, supra note 119 , at 15.

345 Id. 
fish as "driftnet free" would be unenforceable and declined to pass legislation in this respect. ${ }^{347}$ The Papua New Guinea Law Reform Commission also observed that Papua New Guinea depended upon canned fish and any prohibition, particularly of canned fish products from Japan and Taiwan which were considered cheaper and of better quality than canned fish products from other sources, would be publicly unpopul$\operatorname{ar}^{348}$ This same sentiment is likely to be shared by other South Pacific island nations and territories.

Although Article 3(2)(c) invites all parties to prohibit the import of driftnet-caught fish, it seems directed more at those nations with large populations, such as the United States and the United Kingdom. This measure, if implemented in these nations would have serious consequences for the marketability of driftnet-caught fish.

The main difficulty with this Article is that it might be inconsistent with the General Agreement on Tariffs and Trade (GATT) ${ }^{349}$ and any action taken under it similarly inconsistent.

In the dispute between Mexico and the United States, a GATT Panel addressed the issue of whether a party to GATT could prohibit the importation of fish or a fish product which was caught in a manner inconsistent with the internal laws of one of the parties. ${ }^{350}$

The dispute involved the application of the United States Marine Mammal Protection Act (MMPA) which requires the United States Government to prohibit the importation of yellowfin tuna products caught in the eastern tropical Pacific (ETP) unless the vessels' country of registry proves to the United States Government that it has in place a regulatory regime for avoiding the incidental capture of dolphins comparable to the regime held by of the United States. ${ }^{351}$ The MMPA also requires the

377 Correspondence between the author and the New Zealand Ministers of Customs and Consumer Affairs (Nov. 12, 1989 \& Nov. 16, 1989) (on file with the author). New Zealand is also a vociferous supporter of free trade and its position on free trade may also have some bearing on the position taken with regard to prohibiting the importation of fish caught with driftnets.

34 STEWART, supra note 119 , at 15 . 94.

39 General Agreement on Tariffs and Trade, opened for signature Oct. 30, 1947, 55 U.N.T.S.

350 General Agreement on Tariffs and Trade: Dispute Settlement Panel Report on United States Restrictions on Imports of Tuna, August 16, 1990, DS21/R, reprinted in 30 I.L.M. 1594 [hereinafter GATT Panel Report]. See also Ted L. McDorman, The GATT Consistency of U.S. Fish Import Embargoes to Stop Driftnet Fishing, 24 GEO. WASH. J. INT'L L. 477 (1991).

331 Marine Mammal Protection Act, P.L. 92-522, 86 Stat. 1027 (1972), as amended, notably by P.L. 100-711, 102 Stat. 4755 (1988) and most recently by P.L. 101-627 at 104 Stat. 4467 (1990); codified in part at 16 U.S.C. 136lff (U.S.). The United States Govemment had initiated the procedures under the MMPA prohibiting the importation of Mexican tuna caught in the ETP as well as any of this tuna being imported through "intermediary nations," but the Pelly Amend- 
prohibition of importation from "intermediary nations" and triggers section 8 of the Fishermen's Protective Act (Pelly Amendment). ${ }^{352}$

The same Panel Report also addressed the question of whether the United States Dolphin Protection Consumer Information Act (DPCIA) was consistent with the GATT. ${ }^{353}$ The DPCIA provides that when a tuna product exported from or offered for sale in the United States bears the optional label "Dolphin Safe" or any similar label indicating it was fished in a manner not harmful to dolphins, the product must not contain tuna harvested by using driftnets or harvested in the ETP by methods which intentionally encircle dolphins. The use of the label "Dolphin Safe" is not a mandatory requirement, but is voluntary. ${ }^{354}$

Mexico argued in the first instance that the measures imposed by the United States which prohibited imports of yellowfin tuna and yellowfin tuna products from Mexico were quantitative restrictions on importation in breach of Article XI of the GATT, ${ }^{355}$ while the United States argued that these measures were internal regulations enforced at the time or point of importation under Article III:4 and the Note Ad Article $\mathrm{III}^{356}$ of the GATT and that these Articles permitted the prohi-

ment had not been triggered. GATT Panel Report, supra note 350, at 38. See also McDorman, supra note 350 , at 500-1.

352 GATT Panel Report, supra note 350, at 38.

353 Dolphin Protection Consumer Information Act - Section 901, Public Law 101-627, 104 Stat. 4465-67, enacted November 28, 1990, codified in part at 16 U.S.C. 1685. See also GATT Panel Report, supra note 350, at 7.

334 Dolphin Protection Consumer Information Act, § 901, 104 Stat. 4465-67.

355 The relevant part of Article XI reads: "No prohibitions or restrictions . . . whether made effective through quotas, import or export licenses or other measures, shall be instituted or maintained by any contracting party on the importation of any product of the territory of any other contracting party ...." See GATT Panel Report, supra note 350, at 42. See also K.W. DAM. THE GATT: LAW AND INTERNATIONAL ECONOMIC ORGANISATION (1970); McDorman, supra note 350 , at 511-13.

356 The relevant text of Article III:4 reads:

The products of the territory of any contracting party imported into the territory of any other contracting party shall be accorded treatment no less favourable than that accorded to like products of national origin in respect of all laws, regulations and requirements affecting their internal sale, offering for sale, purchase, transportation, distribution or use.

See GATT Panel Report, supra note 350, at 39. The relevant text of Note Ad Article III reads: Any internal tax or other internal charge, or any law, regulation or requirement of the kind referred to in [Article III:1] which applies to an imported product and the like domestic product and is collected or enforced in the case of the imported product at the time or point of importation, is nevertheless to be regarded as an internal tax or other internal charge, or a law, regulation or requirement of the kind referred to in [Article III:1] and is accordingly subject to the provisions of Article III.

Id. 
bition of importation of tuna products from Mexico, subject to certain conditions, ${ }^{357}$ because the prohibition constituted an enforcement of the regulations of the MMPA which also related to the domestic harvesting of tuna. ${ }^{358}$

However, the GATT Panel did not accept the arguments of the United States. The measures taken under the MMPA were determined to be in breach of Article XI and not permitted under Article III:4, which rather than enabling States to regulate the manner in which the product was harvested "calls for a comparison of the treatment of imported tuna as a product with that of domestic tuna as a product. Regulations governing the taking of dolphins incidental to the taking of tuna could not possibly affect tuna as a product." ${ }^{359}$ Furthermore, with regard to Note Ad Article III, again the Panel determined that this Article directs its attention to the regulation of the products or sale of the products, while "the MMPA regulates the domestic harvesting of yellowfin tuna to reduce incidental taking of dolphin ... these. regulations could not be regarded as being applied to tuna products as such because they would not directly regulate the sale of tuna and could not possibly affect tuna as a product." 360

The United States also argued that an embargo of Mexican tuna under the MMPA could be justified under Articles XX(b) or XX(g) of the GATT in that they were measures "necessary to protect human, animal or plant life or health" or were related "to the conservation of exhaustible resources.."

357 Parties to the GATT are permitted by Article III:4 and the Note Ad Article III to impose an internal regulation on products imported from other contracting parties provided it: does not discriminate between products of other countries in violation.of the most-favoured-nation principle of Article I:1; is not applied so as to afford protection to domestic production, in violation of the national treatment principle of Article III:1; and accords to imported products treatment no less favourable than that accorded to like products of national origin, consistent with Article III:4. See id. at 39.

${ }^{3 s s}$ Id.

359 Id. at 41.

350 Id.

351 Article XX of the GATT provides that:

Subject to the requirement that such measures are not applied in a manner which would constitute a means of arbitrary or unjustifiable discrimination between countries where the same conditions prevail, or a disguised restriction on international trade, nothing in this Agreement shall be construed to prevent the adoption or enforcement by any contracting party of measures ....

(b) necessary to protect human, animal or plant life or health;

(g) relating to the conservation of exhaustible natural resources if such measures are made effective in conjunction with restrictions on domestic produc- 
The GATT Panel analyzed Articles $\mathrm{XX}(\mathrm{b})$ and $\mathrm{XX}(\mathrm{g})$ in light of their drafting history and concluded that, in the case of Article $X X(b)$, "if the broad interpretation of Article $\mathrm{XX}(\mathrm{b})$ suggested by the United States was accepted, each contracting party could unilaterally determine the life or health protection policies from which other contracting parties could not deviate without jeopardizing their rights under the General Agreement. The General Agreement would then no longer constitute a multilateral framework for trade among all contracting parties but would provide legal security only in respect of trade between a limited number of contracting parties with identical internal regulation." 362 The measures taken by the United States also did not meet the requirements of necessity provided for in Article $\mathrm{XX}(\mathrm{b}){ }^{363}$ With regard to Article $\mathrm{XX}(\mathrm{g})$, the Panel found, similarly to Article $\mathrm{XX}(\mathrm{b})$, that Article $\mathrm{XX}(\mathrm{g})$ was not intended to have extrajurisdictional application, otherwise "each contracting party could unilaterally determine the conservation policies from which other contracting parties could not deviate without jeopardizing their rights under the General Agreement." ${ }^{\text {"64 }}$ The GATT Panel al-

tion or consumption; . . . .

See id. at 44.

362 Id. at 45. See also McDorman, supra note 350, at 521-23.

363 GATT Panel Report, supra note 350, at 46 . The report stated that:

[t]he United States had not demonstrated to the Panel - as required of the party invoking an Article XX exception - that it had exhausted all options reasonably available to it to pursue its dolphin protection objectives through measures consistent with the General Agreement, in particular through the negotiation of international cooperative arrangements, which would seem to be desirable in view of the fact that dolphins roam the waters of many states and the high seas.

Id.

364 Id. at 47. In the conclusion to its findings the Panel observed that:

the import restrictions imposed in this dispute, imposed to respond to differences in environmental regulation of producers, could not be justified under the exceptions in Articles $\mathrm{XX}(\mathrm{b})$ or $\mathrm{XX}(\mathrm{g})$. These exceptions did not specify criteria limiting the range of life or health protection policies, or resource conservation policies, for the sake of which they could be invoked. It seemed evident to the Panel that, if the CONTRACTING PARTIES were to permit import restrictions in response to differences in environmental policies under the General Agreement, they would need to impose limits on the range of policy differences justifying such responses and to develop criteria so as to prevent abuse. If the CONTRACTING PARTIES were to decide to permit trade measures of this type in particular circumstances it would therefore be preferable for them to do so not by interpreting Article XX, but by amending or supplementing the provisions of the General Agreement or waiving obligations thereunder. Such an approach would enable the CONTRACTING PARTIES to impose such limits and develop such criteria.

See also McDorman, supra note 350 , at 516-21. 
so found that the application of the United States measures relating to "intermediary nations" was in breach of the GATT. ${ }^{365}$

However, with regard to the Dolphin Protection Consumer Information Act, the GATT Panel found that these provisions did not breach the GATT:

the labelling provisions of the DPCIA do not restrict the sale of tuna products; tuna products can be sold freely both with and without the "Dolphin Safe" label. Nor do these provisions establish requirements that have to be met in order to obtain an advantage from the government. Any advantage which might possibly result from access to this label depends on the free choice by consumers to give preference to tuna carrying the "Dolphin Safe" label. The labelling provisions therefore did not make the right to sell tuna or tuna products, nor the access to a government conferred advantage affecting the sale of tuna or tuna products conditional upon the use of tuna harvesting methods. ${ }^{366}$

The implications of this GATT Panel decision for Article 3(2)(c) of the Driftnet Convention appear to be that any prohibition of the importation of any fish or fish product caught using driftnets will be inconsistent with the provisions of the GATT, while the introduction of a voluntary "Driftnet Free" labelling system would be permissible.

The Cook Islands, New Zealand, and Tokelau do not prohibit the importation of fish or fish products caught using driftnets in their legislation implementing the Driftnet Convention. ${ }^{367}$ Australia also drafted legislation to implement a labelling scheme similar to that of the DPCIA in the United States. ${ }^{368}$

\section{g. Other Suggested Measures}

Article 3(3) of the Driftnet Convention states that nothing in the Convention: "shall prevent a Party from taking measures against driftnet fishing activities which are stricter than those required by the Conven-

3 ss GATT Panel Report, supra note 350 , at $48-49$.

365 Id. at 49-50.

357 Marine Resources Act, 1989 (Cook Islands); Driftnet Prohibition Act, 1991 (N.Z.); Tokelau (Exclusive Economic Zone) Fishing Regulations 1988, Amendment No. 1, (SR 1989/268) (N.Z.).

333 See Media Release of the Australian Minister for Justice and Consumer Affairs, Senator Michael Tate (Apr. 19, 1991). Initially it seems that the draft Australian legislation required compulsory labelling of canned tuna with either a statement that the tuna was "Dolphin Safe" or a negative statement on the label indicating that canned tuna may have been caught using a fishing method harmful to dolphins. Documented evidence of the origins of the tuna would be required before any "Dolphin Safe" label would be granted. See also the statement made by Australia in GATT Panel Report, supra note 350, at 26-29. 
tion."369

Thus, Article 3(3) invites parties to take other measures, consistent with international law, against driftnet fishing activities which are stricter than those required by the Convention and this may be interpreted as inviting parties to take measures not contained in the Convention. For example, as mentioned previously, Guam prohibits the manufacture of driftnets within its territory ${ }^{370}$ and the United States invites producers of canned tuna to label their cans "driftnet free," not required by the Driftnet Convention.

A number of measures might also be implemented, imposing further obligations on foreign fishing vessels passing through the fishery zones of coastal states. ${ }^{372}$ These could include requirements to report entry and exit together with proposed routes by fishing vessels navigating through a fishery zones, ${ }^{373}$ use of specified sealanes when passing, ${ }^{374}$ stowing of fishing gear while passing, ${ }^{375}$ and stopping, boarding, and inspecting passing fishing vessels, where there is some indication that they may have been fishing within the fishery zone. ${ }^{376}$

There were also suggestions made, with regard to driftnet fishing in the South Pacific, to confiscate driftnets on the high seas ${ }^{377}$ and to ar-

369 Driftnet Convention 1989, supra note 12, art. 3(3).

330 See supra note 55.

371 See supra notes 353-54 and accompanying text.

372 See generally Burke I 1983, supra note 147; Moore, supra note 126; Robertson, supra note 173 .

${ }^{373}$ Burke I 1983, supra note 147, at 618-20. See also Decree No. 5 of 1979. Control of Foreign Fishing Vessels, $\S 15$ (Sey.). The reporting by foreign driftnet fishing vessels of their entry to and exit from EEZs was suggested as an action that could be taken by coastal States in the South Pacific. See Swan, supra note 317, at 144.

374 Burke I 1983, supra note 147, at 621-22. See also Marine Zones (Declaration) Act 1983, $\S 9$ (Kiribati); Delimitation of Marine Waters Act, 1978, § 10 (Solom. Is.); Marine Zones (Declaration) Ordinance 1983, § 11 (Tuvalu).

37 Burke I 1983, supra note 147, at 620-21. See supra notes 302, 305-6 and accompanying text.

${ }^{376}$ LOS Convention 1982, supra note 58, art. 73. See Burke I 1983, supra note 147, at 602; Moore, supra note 126, at 172; Robertson, supra note 173, at 892-93. See, e.g., Marine Spaces Act 1977, $\S 15$ (Fiji); The Maritime Boundaries Act 1977, \& 27 (Guy.); Coastal Fisheries Protection Act 1953, \& 5 (Can.); The Fisheries Act 1977, \& 32 (Gam.); Fisheries Ordinance 1977 (No. 22), $\S 5$ (Kiribati); Marine Resources Act 1978, § 14 (Nauru); Territorial Sea and Exclusive Economic Zone Act 1977, § 24 (N.Z.); Territorial Sea and Exclusive Economic Zone Act 1978, $\S 18$ (Niue); Public Law No. 6-7-14, 1978, Fisheries Zone Regulations, § 20 (Palau); Marine Fisheries Code Act No. 76-89, § 25 (Sen.); Decree No. 5 of 1979, 9 (Sey.); The Fisheries Act 1972, $\S 10$ (Solom. Is.); Fisheries (Regulation of Foreign Fishing Boats) Act 1979, § 13 (Sri Lanka); Territorial Sea and Exclusive Economic Zone Act 1978, § 23 (Tonga); Tuvalu Fisheries Ordinance, 1978, § 8 .

3n New Zealand Opposition Fisheries Spokesperson, Mr. D Kidd, stated: 
rest driftnet fishing vessels on the high seas. ${ }^{378}$ However, neither of these suggestions were finally implemented and if they had, would have been considered to be of doubtful legal validity. ${ }^{379}$

\section{Enforcement}

Article 4 of the Driftnet Convention establishes the measures to be taken to enforce the Convention:

(1) Each Party shall take appropriate measures to ensure the application of the provisions of this Convention.

(2) The Parties undertake to collaborate to facilitate surveillance and enforcement of measures taken by Parties pursuant to this Convention.

(3) The Parties undertake to take measures leading to the withdrawal of good standing on the Regional Register of Foreign Fishing . Vessels maintained by the FFA against any vessel engaging in driftnet fishing activities. $^{380}$

In order to curtail their activities New Zealand should take initiatives through the Forum to have driftnet fishing banned throughout the whole area, and not just in exclusive economic zones .... If other countries refused to acknowledge the ban Forum Members could decide to enforce it themselves. That would entail fishing up and confiscating driftnets wherever they were found in the South Pacific.

THE Dominion, July 15, 1989, at 2. See also Prime Minister, Mr. D. Lange, The Dominion, July 18, 1989, at 2; Burke, supra note 112, at 296.

378 Arresting vessels was considered by Ministers of the New Zealand Government. Deputy Prime Minister Geoffrey Palmer stated: "I think it is probably contrary to international law now and it may be that people will start arresting vessels - I won't say that the Government is going to do that . . . we will have to look at that." NEW ZEALAND HERALD, July 17, 1989. Prime Minister David Lange also considered this issue. In his view: "it would be legally correct for New Zealand to arrest boats of another country which were fishing in breach of international law on the high seas." THE DOMINION, July 18, 1989. The Japanese Ambassador to New Zealand, Mr Otsuka stated: "if some countries think they can take unilateral action to prevent fishing on the high seas, then I believe this will set a dangerous precedent." CHRISTCHURCH PRESS, Aug. 18, 1989.

379 See Burke, supra note 112, at 270; Kazuo Sumi, International Legal Issues Concerning the Use of Driftnets With Special Emphasis on Japanese Practices and Responses, in FAO Leg. Study 47, supra note 77, at 49-51. Other measures, including application of the territorial sea regime to fishing vessels passing through the exclusive economic zone, prohibition of entry into an exclusive economic zone by unlicensed vessels, and use of transponders, have been considered of doubtful legal validity. See Burke I 1983, supra note 147.

3so Driftnet Convention 1989, supra note 12, art. 4. 


\section{a. Collaboration Regarding Surveillance and Enforcement}

The usual enforcement mechanisms employed by coastal States, involving patrol vessels and aircraft to police the EEZ, are burdensome for the South Pacific island nations and territories because of the vast areas covered by their EEZs and the financial costs of running patrol vessels and aircraft. ${ }^{381}$ As W.T. Burke has observed:

enforcing compliance is very difficult and sometimes an almost impossible and costly task for States with large fishing zones but few resources to devote to enforcement functions. Absent effective enforcement, credibility declines, the management system itself may be threatened, and potential benefits are reduced. Experience has shown that some minimum level of enforcement activity is required if foreign fishermen are to pay heed regularly to applicable regulations. ${ }^{382}$

The general approach taken by the nations and territories of the South Pacific region has been to act regionally to manage their resources and to share the costs of surveillance and enforcement. ${ }^{383}$ In 1984 a Regional Fisheries Surveillance and Enforcement project was set up under the auspices of the Forum Fisheries Agency to promote regional strategies for surveillance and enforcement. ${ }^{384}$

Although these mechanisms were no doubt also used with regard to driftnet fishing in the South Pacific, the primary means of enforcing the prohibition on driftnet fishing in the region were, as previously men-

381 B.M. Tsamenyi, The Exercise of Coastal State Jurisdiction over EEZ Fisheries Resources: The South Pacific Practice, 17 AmBIo 255, 256-57 (1988).

382 Burke I 1983, supra note 147, at 599. See also the comments made by the Papua New Guinea Law Reform Commission: "Control of driftnet fishing, and indeed of all fishing activities, in Papua New Guinea waters depends on efficient surveillance practices ... these are inadequate." STEWART, supra note 119 , at 8.

383 The main regional mechanism for co-operation is the Forum Fisheries Agency, which has as one of its functions the promotion of intra-regional co-ordination and co-operation in "surveillance and enforcement." See South Pacific Forum Fisheries Agency Convention, July 10, 1979. art. 5, in 2 OCEAN Y.B. 578 (1980); 1980 UN Doc. FAO Fisheries Report No. 293 [hereinafter FFA Convention 1979].

384 These strategies included the provision of technical assistance, information, and alternative surveillance equipment to nations of the region, as well as co-ordination of surveillance and enforcement operations, collection, and distribution of information relating to vessel movements within the region, training enforcement officers, and controlling compliance of foreign fishers with the terms and conditions of licensing agreements. See Tsamenyi, supra note 381, at 257; Mizukami, supra note 15, at 113; W.M. Sutherland, Coastal State Co-operation in Fisheries: Emergent Regional Custom in the South Pacific, 1 INT'L J. EstUARINE \& COASTAL L. 23 (1986). 
tioned, port bans, refusal to permit landing of driftnet caught fish, and political pressure. However, Australia and New Zealand did establish a programme for aerial surveillance of driftnet fishing operations in the region, as well as an increase in naval patrols. ${ }^{385}$

\section{b. Withdrawal From the Regional Register}

The third enforcement mechanism in the Driftnet Convention requires parties "to take measures leading to the withdrawal of good standing on the Regional Register of Foreign Fishing Vessels maintained by the FFA against any vessel engaging in driftnet fishing activities." 386

The Regional Register of Foreign Fishing Vessels has been described as "a novel compliance tool designed to meet the particular needs of small island countries ... [and] has attracted international interest since its inception." 387 The Regional Register is maintained by the Forum Fisheries Agency and requires that any foreign vessel seeking to obtain a license or permit to operate in the exclusive economic zone of any member country of the FFA must first register with the Agency. ${ }^{388}$ In July 1989 , the Register had a total of 2,260 vessels listed. ${ }^{389}$

All vessels when first seeking to be registered obtain good standing. ${ }^{390}$ This is done despite any past infringements the vessels may have incurred. ${ }^{391}$ If a vessel then breaches coastal State laws or the terms and conditions of any fisheries access agreement, good standing is withdrawn and that vessel cannot be licensed to fish in the EEZs of any of the FFA member countries. ${ }^{392}$

Consequently, the need to maintain good standing on the Regional

385 Joint Press Statement, Prime Ministers of New Zealand and Australia, 1-2 (Feb. 2, 1990).

3 Sriftnet Convention 1989, supra note 12, art. 4(3).

357 D.J. Doulman \& P. Terawasi, The South Pacific Regional Register of Foreign Fishing Vessels, MARINE POL., July 1990, at 324.

${ }^{3 e s}$ Regional Register of Foreign Fishing Vessels, 1988 Forum Fisheries Agency Report, No. 88/55 [hereinafter FFA Regional Register 1988]. In July 1989 2,260 foreign vessels were registered. This does not mean that all these vessels fish in the region annually.

359 Doulman \& Terawasi, supra note 387 , at $329-30$.

${ }^{350} I d .$, at 3.

391 Id.

392 Id. A vessel's good standing may be withdrawn if: (i) the owner, charterer, operator, master or other person responsible for the operation of that vessel has been convicted of a serious offence against the fisheries laws or regulations of a FFA member country, and the operator has not fully complied with any civil or criminal judgement rendered with respect to the offence; or (ii) evidence exists that gives reasonable cause to believe that the operator has committed a serious offence against the fisheries laws or regulations of any FFA member country and it has not been possible to bring the operator to trial. 
Register is crucial if a fishing vessel wants to continue to fish in the South Pacific region. ${ }^{393}$

As Article 4(3) of the Driftnet Convention provides, vessels engaging in driftnet fishing activities are to have their good standing withdrawn from the Regional Register. ${ }^{394}$ During the period of intensive driftnet fishing in the region, over 100 vessels would have practiced this fishing method. ${ }^{395}$ However, the intention of Article $4(3)$, as to its method of application, is unclear.

The Regional Register operates by withdrawing good standing only from those vessels registered, while those not yet registered may be awarded good standing despite past infringements. It seems the intention in Article 4(3) of the Driftnet Convention is to encourage those vessels with good standing not to engage in driftnet fishing.

If it is assumed that this Article has no retrospective effect, then all vessels which have been engaged in driftnet fishing before the entry into force of the Convention are not covered by this Article. Presumably any vessel with good standing on the Register, which engaged in driftnet fishing, but then ceased before the entry into force of the Convention, maintains its good standing.

Article 4(3) does not specify that the "driftnet fishing activities" must occur within the Convention Area. Consequently, are parties to the Convention required to inquire from vessels seeking to fish in their EEZ whether or not they have been engaged in driftnet fishing activities outside the region subsequent to the entry into force of the Convention and then, if they have, withdraw their good standing?

The Regional Register applies only to fishing vessels, yet the term

393 FFA Regional Register 1988, supra note 388, at 2.

394 Driftnet Convention 1989, supra note 12, art. 4(3). It is understood that no vessel has had its good standing withdrawn from the FFA Register due to driftnet fishing in the South Pacific. Doulman \& Terawasi, supra note 387.

395 Some of the vessels reported to have been engaged in driftnet fishing in the South Pacific and the names of those vessels available to the author were as follows: (1) Yung Pang, Chiu Fu, Jin Hong Shinn, No. I Fuh Kuo, Champion No. I, Der Fu No. 6, San Yu No. 11; (2) Fuji Maru (Japan), Ping Chieh 101 (Taiwan), Ryuko 25 (unknown), Keisia 105 (Japan), Kyosei Maru \# 1 (Japan), Meisyo Maru 105 (Japan); (3) Meisyo Maru No. 101 (unknown), Sankichi Maru No. 18 (Japan); (4) Kyoshin Maru 58, Koei Maru 1, Kofuku Maru, Shoshin Maru 85, Tatumi Maru 1, Koun Maru 32, Ryofuku Maru 23, Kofuku Maru 78, Kyosei Maru 1 \{repeated from above\}, Kinei Maru 81, Iwachi Maru 8, Chokyu Maru 58, Kinei Maru 88, Kannon Maru 17, Kairyu Maru 5, Sachi Maru 58, Shoshin Maru 53, Kyoshin Maru 28, Kashima Mary 58, Choei Maru, Tatsumi Maru 50, Chokyu Maru 32, Tsune Maru 31, Ominato Maru 53, Suwa Maru 18, Inari Maru 16.

Sources; Hampton et al., supra note 4, at 26; COFFEY \& GRACE, supra note 3, at 21-42; L. Bercusson, Waging the War on the Wall, NEW ZEALAND LISTENER \& TV TIMES, Mar. 5 , 1990 , at 10, 12; SPC 4, supra note 146, table 1. 
"driftnet fishing activities" used in Article 4(3) includes activities such as re-provisioning, trans-shipping, etc. ${ }^{396}$ The Regional Register applies to fishing vessels and although Article 4(3) might apply to vessels which engage in "driftnet fishing activities" such as searching for or attempting to locate fish, it is doubtful that it was intended to apply to vessels engaged, for example, in re-provisioning.

Perhaps the intention of Article 4(3), as previously stated, is simply to encourage vessels fishing in the region already registered not to engage in driftnet fishing. However, Article 4(3) could also be interpreted to require that any fishing vessel already registered, which engages in driftnet fishing anywhere in the world, should have its good standing withdrawn. If this interpretation is sustainable and can be successfully enforced, this could be a very important deterrent. ${ }^{397}$ Should the United Nations seek mechanisms to enforce its recommendation that the global moratorium on driftnet fishing be extended from December 1992, then the establishment of a global register of driftnet fishing vessels, based on the FFA Regional Register could become a powerful deterrent. Such a global register could list all vessels engaged in driftnet fishing after December 1992, and parties to the register would then be required to prohibit those vessels from thereafter fishing within their EEZs.

Of the nations which have implemented the Driftnet Convention in the South Pacific, only the Cook Islands specifically provides that a vessel which has engaged in driftnet fishing may be denied a license to fish in Cook Islands fishery waters. ${ }^{398}$ The Cook Islands legislation also provides that the Minister of Fisheries may deny a license to a vessel which does not have good standing on the Regional Register. ${ }^{399}$

\section{c. Enforcement Powers/Penalties}

New Zealand has been the only nation, among those which have implemented the Driftnet Convention, which has produced new separate powers for enforcing the provisions of the Convention. ${ }^{400}$ The other nations which have implemented the Driftnet Convention have relied upon the existing enforcement powers in their general fisheries legislation which provide for powers of boarding, search, inspection, question-

${ }^{396}$ See Driftnet Convention 1989, supra note 12, art. 1(c).

39 There have been discussions that a Pacific-wide Register be developed and that information on vessels be exchanged between subregions. In addition, there has also been support for a global Register. See Doulman \& Terawasi, supra note 387.

338 Marine Resources Act 1989, § 16(6) (Cook Islands).

399 Id. \& 16(6)(e).

Driftnet Prohibition Act, 1991, §§ 13-24 (N.Z.). 
ing, seizure, and arrest. ${ }^{401}$ These powers are generally the same as those provided for by other South Pacific nations. ${ }^{402}$

The penalties for offenses relating to driftnet fishing activities are generally higher and more extensive than those for other fisheries offenses and include fines, ${ }^{403}$ seizure, and forfeiture of property (including catch and vessels). ${ }^{404}$

\section{Further Obligations}

Parties are obliged to consult, review the Convention, and seek to reach agreement with States eligible to become parties to either the Convention or its Protocols. ${ }^{405}$ Parties are also obliged to co-operate, in particular with distant water fishing nations to develop conservation and management measures for South Pacific albacore tuna. ${ }^{406}$

401 Fisheries Act 1952 (Austl.); Marine Resources Act 1989, §§ $30-49$ (Cook Islands); Tokelau (Territorial Sea and Exclusive Economic Zone) Act 1977, § 12 (N.Z.).

402 See FAO REGIONAL COMPENDIUM, supra note 127, at 32-36. Mizukami makes the following observation:

Virtually all of the laws provide for civil and/or criminal sanctions for unlicensed fishing or other illegal fishing in the EEZs. These sanctions generally include such measures as the forfeiture of vessels or properties, seizing the catch, fining the vessels owners, and even imprisoning crew members, when foreign nations are found fishing in the zones without having paid the appropriate fees or otherwise having satisfied the requirement of the fisheries legislation.

Mizukami, supra note 15 , at 113 .

${ }^{403}$ See Fisheries Management Act 1991, $\S 13$ (Austl.); Marine Resources Act 1989, § 15 (Cook Islands); Driftnet Prohibition Act, 1991, \& 25 (N.Z.); Tokelau (Exclusive Economic Zone) Fishing Regulations 1988, Amendment No. 1, New Zealand S.R. 1989/268 (N.Z.).

The maximum fines in those nations which have implemented the Convention are as follows: Australia (50,000 Australian dollars for natural persons who commit an offence and 250,000 Australian dollars for bodies corporate); Cook Islands (250,000 New Zealand dollars for all persons). The New Zealand and Tokelau fines differ depending on what driftnet fishing activity was being carried out. Generally, for New Zealand the maximum fine is 250,000 New Zealand dollars, while in Tokelau the fine is 10,000 New Zealand dollars or if trans-shipping a driftnet catch, 100,000 New Zealand dollars.

Note that the legislation of Guam provides for imprisonment if persons are found in violation of its laws regarding driftnet fishing. The imprisonment of vessel, crew, masters, etc., of foreign. fishing vessels for fisheries offenses is considered contrary to international law and is explicitly not permitted by Article 73(3) of the LOS Convention. LOS Convention 1982, supra note 58, art. 73(3). See also Kuen-Chen Fu, Trespassing Taiwanese Fishing Vessels in Some ASEAN States Waters, 24 U. BRIT. COLUM. L. REV. 109 (1990).

404 Marine Resources Act 1989, §§ 40-49 (Cook Islands); Driftnet Prohibition Act, 1991, § 30 (N.Z.); Tokelau (Territorial Sea and Exclusive Economic Zone) Act 1977, § 12 (N.Z.).

405 Driftnet Convention 1989, supra note 12, arts. 5, 7.

406 Id. art. 8. See Wright \& Doulman, supra note 1, at 323-24; SoUTH PACIFIC FoRUM, supra note 1, at 52-61. 
The Forum Fisheries Agency is to review, analyze, and report on driftnet fishing operations within the Convention Area, and the measures being taken to implement the Convention. ${ }^{407}$ Parties must convey to the Forum Fisheries Agency any measures being taken by them to implement the Convention and any scientific studies they may have undertaken with regard to driftnet fishing. ${ }^{408}$

Regarding signature, ratification, and accession, provision is made within the Convention for States to sign, on their own behalf, or on the behalf of Territories under their control within the Convention Area. ${ }^{409}$ There is also provision for Territories to sign, ratify, or accede where their territorial powers extend to authority over their fishery zones. ${ }^{410}$ Instruments of ratification are to be deposited with the Government of New Zealand, ${ }^{411}$ and the Convention is not subject to reservations. ${ }^{412}$ However, the Convention may be amended by consensus. ${ }^{413}$

The Convention entered into force on the date of deposit of the fourth instrument of ratification. ${ }^{414}$ The Convention is registered with the United Nations in accordance with Article 102 of the Charter of the United Nations $\mathrm{s}^{415}$ and is written in two languages, English and French, which are equally authentic..$^{416}$

\section{Protocols}

The Driftnet Convention is complimented by two additional Protocols. ${ }^{417}$ The Protocols were written to enable distant water fishing nations and other nations seeking to prohibit driftnet fishing in or adjacent to the Convention Area to legally adhere to measures very similar to those of the Driftnet Convention. ${ }^{418}$

The use of Protocols associated with the Driftnet Convention is very similar to their use in the SPNFZ Treaty and the idea to use Proto-

407 Driftnet Convention 1989, supra note 12 , art. 6.

45 Id. art. $6(2)$.

409 Id. arts. 10, 1(a).

410 Id.

411 Id. art. 10(2).

412 Id. art. 11.

43 Id. art. 12.

414 Id. art. 13. The Convention entered into force on May 17, 1991.

4is Id. art. 14.

416 Id.

417 Driftnet Convention Protocol 1 1989, supra note 12; Driftnet Convention Protocol 2 1989, supra note 12.

418 Driftnet Convention Protocol 1 1989, supra note 12, art. 7; Driftnet Convention Protocol 2 1989, supra note 12, art. 7. 
cols in this manner seems to have come from this precedent. ${ }^{419}$

However, there has been some concern as to how the distant water fishing nations are to be persuaded to sign the Protocols, or whether the policy decisions and media statements made by those nations to stop driftnet fishing in the South Pacific are sufficient. ${ }^{420}$

Both Protocols state that they will not affect or prejudice the views or positions of any party with respect to the law of the sea. ${ }^{421}$ This provision does not appear in the Convention itself. In addition, although the Convention itself contains no clause regarding withdrawal, the two Protocols enable parties to the Protocols to withdraw. ${ }^{422}$ Enabling a party to a Protocol to withdraw might have been seen as a mechanism for making the Protocols more favorable to the nations who might sign them. ${ }^{423}$ As there were no withdrawal clauses in the New Zealand draft of the Driftnet Convention or in the Protocols to the second draft of the Driftnet Convention, it may be surmised that the withdrawal clauses were inserted at the final Conference in Wellington, perhaps on advice from, or at the insistence of, the United States, the United Kingdom, or France. ${ }^{424}$

\section{a. Protocol 1}

Protocol 1 to the Driftnet Convention is provided for any distant water fishing nation (for example, Japan or South Korea), whose nationals or vessels fish or fished within the Convention Area. ${ }^{425}$ Parties to this Protocol undertake to prohibit their nationals or fishing vessels from using driftnets within the Convention Area. ${ }^{426}$ The parties are also re-

419 For a discussion of the use of Protocols in the SPNFZ Treaty, see Fyfe \& Beeby, supra note 94 , at $46-49$.

420 Herr 1990, supra note 18, at 30 (Australian Statement: "One point of detail (and not insignificant detail) concerning the proposed convention: have we given sufficient thought to how the driftnetters are to be persuaded to sign the protocols or do the recent Japanese decisions indicate that it is sufficient for us simply to stand firm.").

421 Driftnet Convention Protocol 1 1989, supra note 12, art. 1; Driftnet Convention Protocol 2 1989, supra note 12, art. 1.

422 Driftnet Convention Protocol 1 1989, supra note 12, art. 6; Driftnet Convention Protocol 21989 , supra note 12, art. 6.

423 This was the reason for including a withdrawal clause in the Protocols to the SPFNZ Treaty. Fyfe \& Beeby, supra note 94, at 49 ("some nuclear weapon States, during the consultations on the Protocols, advised that the absence of a right to withdraw cast in liberal terms could adversely affect their decision as to signature.").

${ }^{424}$ See Driftnet Convention - New Zealand Draft 1989, supra note 17; Driftnet Convention Second Draft 1989, supra note 18.

125 Driftnet Convention Protocol 1 1989, supra note 12, art. 7.

425 Id. art. 2. 
quired to furnish the Forum Fisheries Agency with any information on, or scientific analyses on the effects of, driftnet fishing activities relevant to the Convention Area ${ }^{427}$ In addition, parties are to co-operate in the development of the Arrangement relating to the Management of South Pacific Albacore Tuna. ${ }^{428}$

\section{b. Protocol 2}

Protocol 2 is open to signature by any State, "the waters under the jurisdiction of which are contiguous with or adjacent to the Convention Area," or by any other State invited to sign. ${ }^{429}$

Parties to Protocol 2 are required to take measures identical with those contained in Articles 2 and 3 of the Driftnet Convention. ${ }^{40}$ Many of these measures would apply, not only to the Driftnet Convention Area, but also to the party's own fisheries zones and territory. ${ }^{431}$

The measures which parties must take include prohibiting their nationals or vessels from using driftnets within the Convention Area and not assisting or encouraging the use of driftnets within the Convention Area. ${ }^{432}$ In addition, parties must take measures, consistent with international law, to prohibit the use of driftnets within areas under their own fisheries jurisdiction and the trans-shipment of driftnet catches within areas under their own jurisdiction. ${ }^{433}$

There also follow discretionary measures which parties may take, consistent with international law, to prohibit the landing and processing of driftnet catches, to prohibit the importation of any fish or fish product which was caught using a driftnet, to restrict port access and port servicing facilities to driftnet fishing vessels, and to prohibit the possession of driftnets on board any vessel within areas under their fisheries jurisdiction. ${ }^{434}$ Parties may also take measures against driftnet fishing

127 Id. art. 3.

423 Id. art. 4.

428 Driftnet Convention Protocol 2 1989, supra note 12, art. 7. The Final Act of the Driftnet Convention mentions that the words "adjacent to the Convention Area" in Article 7 of the Driftnet Convention Protocol 2 relate to countries on or within the Pacific rim. See Driftnet Convention Final Act, supra note 12. Presumably this could include Indonesia, the Philippines, Malaysia, Vietnam, China, Russia, Canada, the United States, Mexico, Guatemala, El Salvador, Honduras, Nicaragua, Costa Rica, Panama, Colombia, Ecuador, Peru, and Chile.

130 Driftnet Convention Protocol 2 1989, supra note 12, arts. 2, 3.

431 Id.

132 Id. arts. 2, 3(1)(a).

${ }^{433}$ Id. art. 3(1)(b).

434 Id. art. 3(2). 
activities which are stricter than those required by the Protocol. ${ }^{435}$ The parties are also required to furnish to the FFA any information on, or scientific analyses on the effects of, driftnet fishing activities relevant to the Convention Area. ${ }^{436}$

\section{c. Taiwan}

Due to difficulties over the recognition of Taiwan, a mechanism was adopted whereby the Director of the Forum Fisheries Agency was to exchange letters with the Taiwan Deepsea Tuna Boat Owners and Exporters Association. ${ }^{437}$ The letter from the Director of the Forum Fisheries Agency invited the Association to "undertake to ban its members and prevent their fishing vessels from using driftnets within the Convention Area." ${ }^{\text {"438 }}$ A further draft letter from the Chairman of the Taiwan Deepsea Tuna Boat Owners and Exporters Association to the Director of the FFA simply accepted the proposal of the Director. ${ }^{439}$

\section{CONCLUSION}

The Driftnet Convention combines both a political and a legal response to driftnet fishing in the South Pacific. D.M. Johnston describes the Convention as:

an effort to build a panregional coalition of coastal states, with language designed to tolerate fairly diverse national policies and enactments but pivoting on a shared policy against large-scale driftnetting both inside EEZ limits and in the high seas beyond. How far these states will feel they can go with preventative and punitive measures will depend in large part on their interpretation of what is "consistent with international law," and therefore on both established and emerging legal principles applied to fishery management in the high seas. ${ }^{440}$

The precedent for the format of the Driftnet Convention is the South Pacific Nuclear Weapon Free Zone (SPNFZ) Treaty, which also

${ }^{435}$ Id. art. 3(3).

436 Id. art. 4.

437 Driftnet Convention Draft Exchange of Letters, supra note 12.

438 Id.

439 Wright \& Doulman, supra note 1, at 319. Wright and Doulman also state that: "[a]t the Singapore meeting between Taiwanese officials and South Pacific representatives it was pointed out that the Taiwan Deepsea Tunaboat Owners and Exporters Association, an industry group, could not enter into a legal and binding commitment with respect to driftnetting in the South Pacific on behalf of the Taiwanese Government." Id.

440 D.M. Johnston, The Drifinetting Problem in the Pacific Ocean: Legal Considerations and Diplomatic Options, 21 OCEAN DEV. \& INT'L L. 5 (1990). 
combines a main Treaty, designed to be signed by parties from the South Pacific region, followed by Protocols, designed to be signed by parties from outside the region who are actually engaged in the activities which are the focus of the Treaty. ${ }^{441}$ While both the SPNFZ Treaty and the Driftnet Convention also act as major political statements, they are also binding legal instruments (therefore carrying more commitment than a political commitment) which reflect the united resolve of the nations inside the region.

To date, fifteen nations and territories have signed the Driftnet Convention. ${ }^{42}$ The United States has signed and ratified Protocol 1 while Canada and Chile have signed Protocol 2..43 Nine countries: Australia; the Cook Islands; the Federated States of Micronesia; Fiji; Kiribati; Nauru; New Zealand; Tokelau; and the United States have ratified the Convention which came into force on 17 May $1991 .^{444}$ However, the three distant water fishing nations which engaged in driftnet fishing in the South Pacific have not signed the Protocols or, in the case of Taiwan, the exchange of letters. ${ }^{45}$

Apart from its role as a political statement, the Convention also binds those nations which ratify it to implement its mandatory provisions and consider implementation of its discretionary provisions. These provisions contain some important, and in some respects, unique legal obligations.

The Convention prescribes measures to be taken by parties against driftnet fishing. These are found in Articles 2 and 3 of the Convention and similar provisions are also contained in the Protocols. ${ }^{446}$ The measures are divided into measures which are mandatory and those which are discretionary. ${ }^{447}$

At least two commentators have found some provisions of the Convention to be inconsistent with international law. ${ }^{48}$ Although it appears that almost all of the provisions are in fact consistent with international law, those provisions which invite parties to prohibit transportation of

41 SPNFZ Treaty 1985, supra note 11. See Fyfe \& Beeby, supra note 94.

42 See supra note 23 and accompanying text.

${ }^{43}$ See supra note 24 and accompanying text.

44 See supra note 25 and accompanying text.

4s Wright \& Doulman, supra note 1 , at 320.

4s Driftnet Convention 1989, supra note 12, arts. 2, 3; Driftnet Convention Protocol 1, 1989. supra note 12, arts. 2, 3; Driftnet Convention Protocol 2, supra note 12, arts. 2, 3.

47 Articles 2 and $3(1)$ of the Driftnet Convention establish the mandatory measures, while Article 3(2) and 3(3) establish the discretionary measures.

4s See generally Mizukami, supra note 15; Shearer, supra note 15. 
driftnet caught fish, ${ }^{449}$ possession of driftnets within areas under a party's fisheries jurisdiction, ${ }^{450}$ and importation of fish caught with driftnets $^{451}$ may, if implemented strictly, be inconsistent with other international legal requirements.

Although the Driftnet Convention does not seek to extend coastal State jurisdiction onto the high seas of the South Pacific region, the inclusion of considerable areas of high seas within the Convention Area is a reflection of regional "stewardship" over the high seas and its resources. ${ }^{42}$ The provisions of the Convention also make driftnet fishing on the high seas of the region extremely difficult, not by prohibiting activities on the high seas, but by prohibiting activities, such as transshipment, within areas under a coastal State's jurisdiction, which make the operations of a high seas fishery, particularly in the remote areas of the South Pacific Ocean, extremely difficult. Despite the Driftnet Convention having been drafted to restrict driftnet fishing activities in the South Pacific region, it does act as a useful precedent and could, with a few amendments, be applicable globally. Indeed some of the nations which have ratified the Convention have enacted legislation which makes the measures contained in the Convention applicable to their nationals globally (for example, Australia and the Cook Islands prohibit their nationals from engaging in driftnet fishing activities anywhere). ${ }^{453}$

While the United Nations has recommended a Global moratorium of driftnet fishing on the high seas by the end of 1992, it has not established any mechanisms to achieve that goal. ${ }^{454}$ Should high seas driftnet fishing continue despite the recommendation of a global moratorium, then perhaps a global version of the South Pacific Driftnet Convention would be warranted.

49 See supra notes $275-91$ and accompanying text.

450 See supra notes $292-315$ and accompanying text.

451 See supra notes $345-68$ and accompanying text.

452 See supra notes 82-113 and accompanying text.

${ }^{453}$ See supra notes 40, 47-48 and accompanying text.

44 UNGA Resolution 46/215 (XLVI) 1991. 